UNIVERSIDADE DE SÃO PAULO
ESCOLA DE EDUCAÇÃO FÍSICA E ESPORTE DE RIBEIRÃO PRETO

Felipe Modolo

A Formação esportiva do goleiro de handebol: características apontadas

pelos treinadores da categoria sub-16

Ribeirão Preto

2017 
FELIPE MODOLO

\title{
A Formação Esportiva do Goleiro de Handebol: características apontadas pelos treinadores da categoria sub-16
}

\begin{abstract}
Versão Corrigida
(Versão original encontra-se na EEFERP-USP, que aloja o Programa de Pósgraduação)

Dissertação apresentada ao Programa de PósGraduação da Escola de Educação Física e Esporte de Ribeirão Preto da Universidade de São Paulo para obtenção do título de Mestre em Educação Física e Esporte.

Linha de Pesquisa: Aspectos Pedagógicos e Socioculturais do Esporte
\end{abstract}

Orientador: Prof. Dr. Rafael Pombo Menezes

Ribeirão Preto

2017 
Autorizo a reprodução e divulgação total ou parcial deste trabalho, por qualquer meio convencional ou eletrônico, para fins de estudo e pesquisa, desde que citada a fonte.

\section{Modolo, Felipe}

A Formação Esportiva do Goleiro de Handebol:

características apontadas pelos treinadores da categoria sub-16. Ribeirão Preto, 2017. $127 \mathrm{f}$.

Dissertação de Mestrado, apresentada à Escola de Educação Física e Esporte de Ribeirão Preto/USP. Área de concentração: Atividade Física e Esporte.

Orientador: Menezes, Rafael Pombo.

1. Handebol. 2. Goleiro de Handebol. 3. Ensino-aprendizagemtreinamento. 
MODOLO, F. A Formação Esportiva do Goleiro de Handebol: características apontadas pelos treinadores da categoria sub-16. 2017. 127 f. Dissertação (Mestrado em Educação Física e Esporte) - Escola de Educação Física e Esporte de Ribeirão Preto, Universidade de São Paulo, 2017.

Aprovado em:

Banca Examinadora

Prof. Dr.

Instituição:

Julgamento:

Prof. Dr.

Instituição:

Julgamento:

Prof. Dr.

Instituição:

Julgamento 


\section{AGRADECIMENTOS}

Agradeço a Deus, a meu pai José Roberto, minha mãe Cátia e minhas irmãs Carolina e Thaís pelo apoio incondicional neste período de mudança e de novos desafios.

Agradeço a minha namorada Milena, pelo apoio, pelo carinho e pela força que sempre me deu durante este período, o que me manteve focado para que eu pudesse dar continuidade ao desenvolvimento deste trabalho.

Agradeço às minhas companheiras de apartamento 105, Mari e Mamá, pelas risadas, correções de artigos e strogonoffs que compartilhamos nestes dois anos.

Agradeço aos meus grandes amigos: Érick “C.”, Nassif, Paulo, Johny, Pedro, Patrick "Ksk" e Maurício "XT" pelas risadas e jogatinas (no tempo livre).

Agradeço a Prof ${ }^{a}$ Heloísa, ao $\operatorname{Prof}^{o}$ Enrico e ao $\operatorname{Prof}^{o}$ Riller pelo aceite em fazer parte de minha banca e pelas contribuições feitas ao meu trabalho.

Agradeço ao Prof ${ }^{o}$ Rafael Pombo Menezes pela orientação, pelas conversas de quadra e por todo o apoio que me ofereceu no desenvolvimento deste trabalho.

Agradeço a todos que de alguma forma contribuíram, direta ou indiretamente, para que eu conseguisse realizar este trabalho. 
RESUMO

\author{
MODOLO, F. A Formação Esportiva do Goleiro de Handebol: características \\ apontadas pelos treinadores da categoria sub-16. 2017. 127 f. Dissertação \\ (Mestrado em Educação Física e Esporte) - Escola de Educação Física e Esporte \\ de Ribeirão Preto, Universidade de São Paulo, 2017.
}

O handebol é um jogo esportivo coletivo (JEC) cuja lógica interna regula as interações entre jogadores e equipes. Com o goleiro de handebol isto não é diferente, pois em seu processo de ensino-aprendizagem-treinamento (EAT) é preciso considerar a influência das capacidades motoras, psicológicas e técnico-táticas em função das exigências que são determinadas ao posto específico. Sendo o treinador, o responsável pelo planejamento e condução do processo de EAT, sua opinião é fundamental para que seja possível compreender quais as características que podem influenciar na ação do goleiro de handebol. Assim, o objetivo geral deste trabalho foi identificar as diretrizes para o processo de EAT do goleiro de handebol. Para identificar o panorama da literatura sobre o goleiro de handebol, foi feita uma revisão sistemática sobre o ensino e análise de jogo desse posto específico. Para o desenvolvimento da pesquisa, foi utilizada uma abordagem qualitativa, por meio da realização de entrevistas semiestruturadas com os treinadores da categoria sub-16 que atuavam em duas ligas regionais do Estado de São Paulo. Para a tabulação e análise das entrevistas foi utilizado o método Discurso do Sujeito Coletivo (DSC). Os achados da revisão sistemática apontaram que os estudos com goleiros de handebol são recentes e, por essa razão, foram identificadas algumas lacunas na literatura, como os estudos com goleiros jovens e os estudos com treinadores, que são características da presente pesquisa. Após a análise dos discursos dos treinadores, foi possível identificar que, para a categoria sub-16, o processo de EAT do goleiro de handebol deve ser pautado no desenvolvimento de um repertório motor amplo que facilite o aprendizado das técnicas específicas exigidas pelo jogo. Essas características irão pautar suas ações na fase defensiva para conseguir defender os diferentes tipos de arremesso, a partir da capacidade de leitura dos sinais relevantes que podem influenciar as ações que o goleiro pode fazer em jogo. Essa leitura deverá ser capaz de identificar sinais como o braço de arremesso, o gestual técnico e as trajetórias do adversário. $\mathrm{Na}$ fase ofensiva, o goleiro deve ser estimulado a compreender o modelo de jogo de sua equipe para que possa dar orientações técnico-táticas aos jogadores de quadra, como os espaços para atacar em vantagem numérica e possíveis feedbacks relacionados ao comportamento do goleiro adversário. Nesta fase, o goleiro também deve procurar repor a bola em jogo rapidamente após fazer uma defesa ou recuperar a posse de bola próximo a sua área. Esse comportamento pode favorecer o ataque da sua equipe, ao obter vantagens como acelerar o ataque e dificultar o retorno defensivo do adversário.

Palavras chave: Handebol; Goleiro de Handebol; Ensino-Aprendizagem-Treinamento 


\begin{abstract}
MODOLO, F. The Handball Goalkeeper's Training: characteristics pointed out by the coaches of the U16 category. 2017. $127 \mathrm{f}$. Dissertação (Mestrado em Educação Física e Esporte) - Escola de Educação Física e Esporte de Ribeirão Preto, Universidade de São Paulo, 2017.
\end{abstract}

Handball is a team sport whose internal logic regulates the interactions between players and teams. With the handball goalkeeper this is not different, because in its teaching-learningtraining process (TLT) it is necessary to consider the influence of the motor, psychological and technical-tactical abilities these are recquired for the specific position. As the coach is responsible for planning and conducting the TLT process, his opinion is fundamental so that it is possible to understand what characteristics may influence the handball goalkeeper action's. Therefore, the main objective of this work was to identify the guidelines for the TLT process of the handball goalkeeper. In order to identify the literature overview about the handball goalkeeper, a systematic review researched about the teaching process and game analysis of this specific position. For the development of this research, a qualitative approach was used, through semi-structured interviews with U-16 coaches who played in two regional leagues in the state of São Paulo in 2016. For the tabulation and analysis of the interviews, the Collective Subject Discourse (CSD) method was used. The findings of the systematic review pointed out that studies with handball goalkeepers are recent and, for this reason, some lack in the literature have been identified, such as studies with young goalkeepers and studies with coaches, which are characteristics of the present research. After analyzing the coaches' speeches, it was possible to identify, for the sub-16 category, that the handball goalkeeper TLT process should be based on the development of a broad motor repertoire that facilitates the learning of the specific techniques recquired by the game. These characteristics will guide his actions in the defensive phase to be able to defend the different types of throw, from the ability to identify the relevant signals that can influence the goalkeeper actions inside the game. This ability should be able to identify signals such as the throwing arm, the technical gesture and the oponente trajectories before the throwing. In the offensive phase, the goalkeeper must be encouraged to understand his team's game model so that he can give technical-tactical guidance to court players, such as spaces to attack in numerical advantage and possible feedbacks related to the behavior of the opponent's goalkeeper. At this phase, the goalkeeper should also seek to reset the ball in play quickly after making a defense or regaining possession of the ball near his area. This behavior can favor your team's attack by gaining advantages such as accelerating the attack and hampering the opponent's defensive return.

Key-Words: Handball; Handball Goalkeeper; Teaching-Learning-Traning 


\section{LISTA DE FIGURAS}

Figura 1. Número de artigos científicos publicados por ano.

Figura 2. Porcentagem do número de autores por artigo 20

Figura 3. Média de autores por artigo ao longo do período observado

Figura 4. Percentual de publicações de acordo com os países das universidades.

Figura 5. Percentual de publicações referentes ao idioma 22

Figura 6. Quantidade de artigos sobre as temáticas de ensino e análise de jogo do goleiro de handebol 22

Figura 7. Indicativos de ação do goleiro de handebol na categoria sub-16 baseado na opinião dos treinadores entrevistados 70

Figura 8. Características do processo de formação do goleiro de handebol na categoria sub-16 


\section{LISTA DE QUADROS}

Quadro 1: Artigos encontrados na busca inicial em diferentes bases de dados e posteriores fases de seleção.

Quadro 2. Características dos artigos sobre a temática de análise de jogo do goleiro de handebol.

Quadro 3. Características dos artigos sobre a temática de ensino do goleiro de handebol

Quadro 4. Instrumento de entrevista semi estruturada. 40

Quadro 5. IC e DSC referentes à questão: "O que o goleiro deve observar no ataque do adversário para fazer a defesa?.

Quadro 6. IC e DSC referentes à questão: "O que o goleiro deve observar no ataque da sua equipe?".

Quadro 7. IC e DSC referente à questão: "O que o goleiro deve fazer para defender um arremesso em diferentes distâncias?".....

Quadro 8. IC e DSC referentes à questão: “Quais são as principais capacidades técnico-táticas a serem desenvolvidas pelo goleiro de handebol na categoria sub-16? Que patamares você espera que essas capacidades alcancem?"

Quadro 9. IC e DSC referentes à questão: “Quais as características que você considera para a especialização do goleiro de handebol?" 
INTRODUÇÃO ............................................................................................................................ 11

OBJETIVOS...................................................................................................................................... 14

CAPÍTULO 1 - REVISÃO SISTEMÁTICA SOBRE O GOLEIRO DE HANDEBOL................. 15

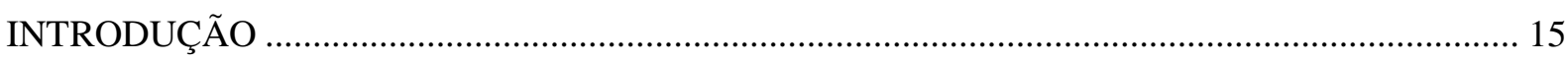

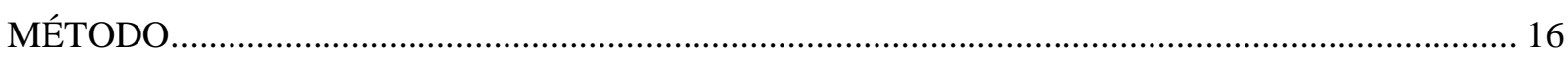

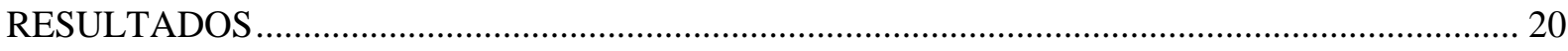

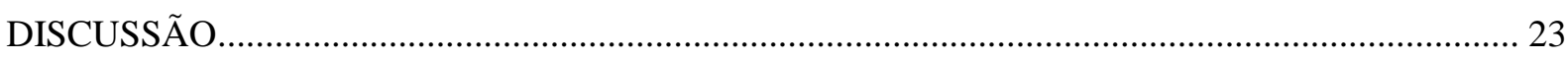

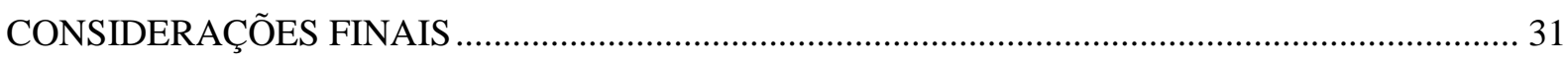

CAPÍTULO 2 - MÉTODOS …………………………………........................................................... 37

TIPO DE PESQUISA ……………………………………………………………… 37

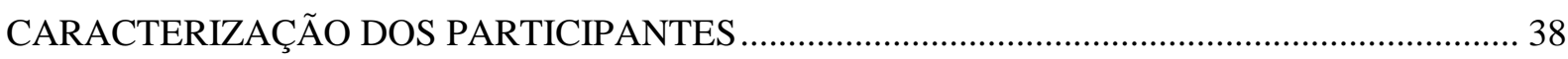

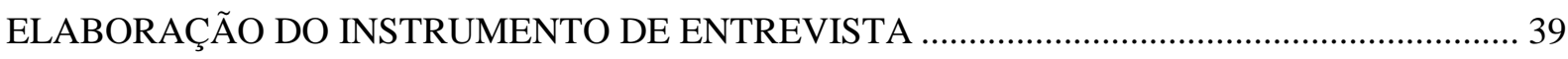

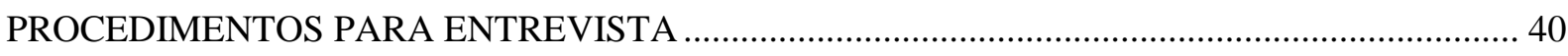

ANÁLISE DAS ENTREVISTAS: O DISCURSO DO SUJEITO COLETIVO.................................... 42

CAPÍTULO 3 - AÇÕES DO GOLEIRO DE HANDEBOL EM SITUAÇÃO DE JOGO ............. 44

O QUE O GOLEIRO DEVE OBSERVAR NO ATAQUE DO ADVERSÁRIO PARA DEFENDER 44

O QUE O GOLEIRO DEVE FAZER PARA DEFENDER UM ARREMESSO EM DIFERENTES

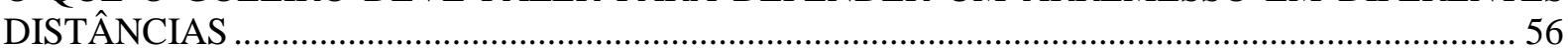

CAPÍTULO 4 - CARACTERÍSTICAS QUE SUPORTAM AS AÇÕES DO GOLEIRO DE HANDEBOL ....................................................................................................................................... 71

AS CARACTERÍSTICAS TÉCNICO-TÁTICAS NA FORMAÇÃO DO GOLEIRO DE HANDEBOL

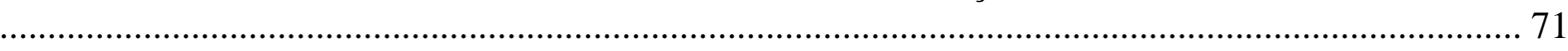

AS CARACTERÍSTICAS CONSIDERADAS PARA A ESPECIALIZAÇÃO DO GOLEIRO DE

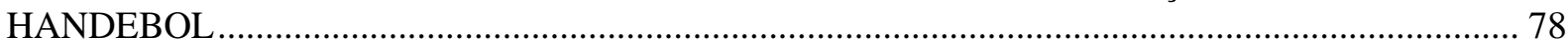

CONSIDERAÇÕES FINAIS ................................................................................................................... 91

REFERÊNCIAS BIBLIOGRÁFICAS .................................................................................95

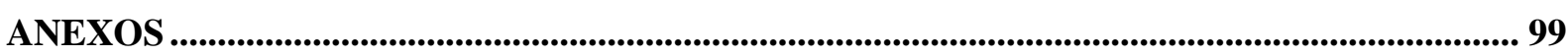

ANEXO A - Termo de Consentimento Livre e Esclarecido …………………………………………..... 99

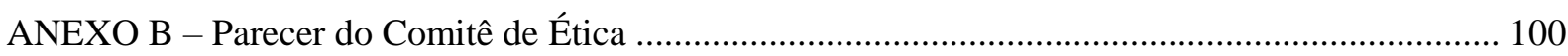

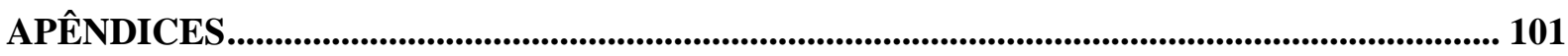

APÊNDICE A - Transcrição das respostas do bloco de "Dados Pessoais" do instrumento de entrevista

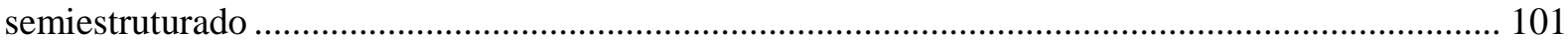

APÊNDICE B - Transcrição das respostas do bloco de "Características dos Goleiros na Categoria sub16" do instrumento de entrevista semiestruturado ............................................................................ 109 
INTRODUÇÃO

O handebol é um jogo esportivo coletivo (JEC) (BAYER; 1994; GARGANTA; 1998) cuja lógica interna é regida por uma série de parâmetros que vão regular as interações entre jogadores e equipes durante o jogo. Esses parâmetros, segundo Oliver Coronado \& Sosa González (1996, apud MENEZES; REIS, 2010), surgem da relação entre as estruturas fixas do jogo (dimensões da quadra, bola, tempo de jogo, regulamento) e as estruturas variáveis do jogo (número de jogadores, sistemas de jogo e formas de execução dos gestos técnicos).

Sobre essa relação aponta-se que os elementos que compõem o jogo de handebol, categorizados em meios técnico-táticos ofensivos individuais e coletivos; meios técnico-táticos defensivos individuais e coletivos; sistemas defensivos e sistemas ofensivos (MENEZES; 2011) são enfatizados de acordo com a categoria (faixa etária), seja pela diferença no tamanho da bola, pelo tempo de jogo ou mesmo pela atuação da arbitragem (RAMARI, 2008; MENEZES; REIS; TOURINHO FILHO, 2015).

Se pensarmos o jogo na sua unidade mais individualizada, ou seja, cada jogador e o posto específico que ocupa, pode-se perceber que as ações diferem de acordo com o posto que ocupam. Isso ocorre porque cada posto tem a sua especificidade no âmbito físico, psicológico e técnico-tático. Além disso, o jogo é complexo pois possui uma grande dimensão tática (GARGANTA, 1998; WAGNER et al, 2014), o que exige dos jogadores, independentemente do posto específico, um bom desenvolvimento de suas características cognitivas (MATIAS, GRECO; 2010).

Mesmo sendo influenciado pelos mesmos fatores que regulam as ações do jogo como um todo, o goleiro de handebol tem como função proteger o gol, função essa que está atrelada aos princípios operacionais defensivos dos JEC (BAYER, 1994). Dessa forma, para exercer esta função, o posto do goleiro de handebol também apresenta algumas especificidades relacionadas às características físicas, antropométricas, técnico-táticas, cognitivas e psicológicas.

Por ter jogado como goleiro de handebol por mais de 15 anos, vivenciei diferentes métodos de treino e recebi várias informações ao longo de minha trajetória esportiva. Atualmente, ao refletir sobre essas experiências, percebo que muitos pontos ao longo da minha formação como goleiro não foram bem trabalhados, especialmente, aqueles relacionados ao 
entendimento do jogo, sobre saber o que está fazendo e não somente reproduzir uma série de gestos técnicos (muitas vezes sem sentido).

Como treinador de handebol ainda possuo uma dificuldade para identificar quais características devem ser enfatizadas na formação do goleiro de acordo com a sua faixa etária, para que se evite uma reprodução dos treinos das categorias adultas. Além disso, em jogos de categorias jovens, vejo vários treinadores dando feedbacks de maneira pouco clara para o atleta jovem como: "as bolas da ponta sai sempre com as mãos altas" ou "o contra-ataque, faz sempre a defesa em X”. Esses feedbacks carecem do entendimento, por parte do atleta, do porquê devem fazer dessa forma (e se devem fazer) nessa situação, o que nem sempre é deixado claro para esses, que acabam apenas reproduzindo tais ações em qualquer situação do jogo, sem ao menos pensar sobre isso. Talvez esses comportamentos exigidos pelos treinadores também não sejam tão claros para eles próprios, por reproduzirem essas ações baseadas em experiências anteriores que podem ter ocorrido em um contexto diferente do seu. Essa situação torna a sua aplicação ainda mais difícil por não considerar toda a complexidade que envolve o seu contexto de atuação (JONES, 2006).

Em relação ao parágrafo anterior, existem alguns autores que pesquisaram sobre a formação do goleiro de handebol e destacaram que o treinamento do goleiro jovem deve ser desenvolvido de acordo com a sua faixa etária e não apenas uma reprodução do que se faz na categoria adulta (GÓMEZ, 2007; ROMERO NOVOA, 2012). Todavia, há ainda uma lacuna de estudos com as categorias jovens no handebol, especialmente com os goleiros, que será apresentada no Capítulo 1.

Assim, considerando a importância do goleiro para o desenvolvimento do jogo, a ausência de informações sobre o conteúdo das diferentes fases de formação do goleiro de handebol e a necessidade de evidências para decisões no âmbito do treino, para a realização deste trabalho, foram traçados como os objetivos principais desta pesquisa: a) a identificação das características importantes para formar um goleiro de handebol, respeitando suas fases de desenvolvimento de acordo com a sua faixa etária; e b) identificar essas características a partir do que pensam os treinadores.

Dessa forma, este trabalho foi estruturado em quatro capítulos para melhor explicar como os objetivos traçados foram contemplados. No Capítulo 1 foi realizada uma revisão sistemática sobre o ensino e a análise de jogo do goleiro de handebol, de modo a traçar um 
panorama da pesquisa nessas áreas, sobretudo as características dos trabalhos, as principais tendências apresentadas e as lacunas identificadas.

No Capítulo 2 são apresentados os métodos que foram utilizados na realização desta pesquisa, como a escolha do tipo de pesquisa, da caracterização dos sujeitos, dos procedimentos para a coleta (entrevista semi-estruturada) e análise dos dados (Discurso do Sujeito ColetivoDSC).

Os resultados e a discussão das entrevistas serão apresentados nos dois capítulos finais. No Capítulo 3, serão discutidos os discursos dos treinadores referentes aos principais achados sobre as ações do goleiro de handebol em situação de jogo. No Capítulo 4, serão discutidos os discursos dos treinadores referentes às características técnico-táticas importantes que dão suporte às ações do goleiro e às características necessárias para a especialização no posto do goleiro de handebol. 


\section{OBJETIVOS}

Geral

- Identificar as diretrizes para a formação esportiva do goleiro de handebol na categoria sub-16 pautando-se na opinião dos treinadores.

\section{Específicos}

- Identificar as ações que o goleiro de handebol deve realizar de acordo com a fase de jogo;

- Identificar as ações que o goleiro de handebol deve realizar de acordo com a distância dos arremessos;

- Verificar quais são as características técnico-táticas que suportam as ações do goleiro de handebol na categoria sub-16;

- Verificar as características consideradas para a especialização do goleiro de handebol. 
CAPÍTULO 1 - REVISÃO SISTEMÁtICA SOBRE O GOLEIRO DE HANDEBOL

\section{INTRODUÇ̃̃O}

O goleiro de handebol apresenta algumas especificidades em seu posto, sobretudo por ser considerado o último jogador a tentar evitar o gol adversário e o primeiro jogador a iniciar as ações ofensivas de sua equipe. Arias Estero (2009) destaca que o goleiro tem as suas intenções defensivas, caracterizadas pela alta concentração sobre as ações da equipe adversária, procurando se manter bem posicionado para facilitar a sua interceptação a bola. Para Antúnez Medina (2003) as habilidades específicas principais de um goleiro estão divididas em quatro: a sua posição-base; o seu controle da situação de jogo em relação ao seu posicionamento e o posicionamento da bola; os deslocamentos para executar as defesas a bola e por fim, as ações de defesa do goleiro.

Percebe-se assim, que o posto do goleiro de handebol é influenciado por várias características e que todas elas contribuem para o seu desempenho em uma partida. A efetividade do goleiro de handebol deve ser entendida como o resultado da interação de múltiplos fatores, como as capacidades físicas, psicológicas, técnico-táticas (ESPINAAGULLO et al., 2016), que devem ser abordadas e avaliadas ao longo do período de ensino e durante situações competitivas.

Por se tratar de um posto específico com atribuições diferentes em relação aos jogadores de quadra, torna-se importante verificar aspectos que estão relacionados ao processo de ensino e de análise dos goleiros de handebol. Nesse sentido, o desempenho do goleiro pautase na interação de diversas características. É preciso então, descobrir que características devem ser abordadas em uma perspectiva de longo prazo. O treinamento dos goleiros apresenta, assim, diferenças em aspectos como a especificidade das ações e, por muitas vezes, ocorre de forma separada dos jogadores de quadra.

O crescente interesse de pesquisadores por estudos envolvendo o handebol já foi abordado nas revisões sistemáticas realizadas por Aguillar (2014) e Prieto, Gómez e Sampaio (2015). O objetivo desses estudos foi analisar a produção científica existente sobre o handebol 
ao longo dos anos, porém não foram apontadas perspectivas para o estabelecimento de um panorama que envolvesse os goleiros de handebol.

A revisão sistemática é um tipo de pesquisa no qual busca-se responder a uma pergunta, por meio da identificação, seleção e análise das pesquisas relevantes em uma determinada área (GALVÃO; PANSANI; HARRAD, 2015), para identificar o estado da arte de um determinado campo de estudo, verificando a sua produção científica com base em critérios pré-estabelecidos (SÁNCHEZ-MECA, 2010). Além disso, permite identificar possíveis lacunas de pesquisa a serem exploradas pelos pesquisadores (FERNÁNDEZ-RÍOS; BUELA-CASAL, 2009).

Sendo o handebol um esporte mundialmente difundido, este pode ser um fator de interesse para cientistas de diferentes áreas, ao produzirem artigos/trabalhos científicos sobre esse esporte (AGUILAR, 2014; PRIETO; GÓMEZ; SAMPAIO, 2015), pois existem várias possibilidades de pesquisas. Além do grande número de pessoas envolvidas com o handebol (treinadores, atletas, dirigentes, etc) que tem nas pesquisas desenvolvidas uma fonte de conhecimento confiável e validada cientificamente.

Toma-se como linha de base para esta revisão a temática referente ao goleiro de handebol, pautando-se nas intrínsecas relações entre treino e jogo (GARGANTA, 2009). Espera-se, para tanto, que seja revelado um panorama das pesquisas relacionadas às questões de ensino/treinamento do goleiro e da análise do seu desempenho em jogo. Assim, o objetivo desta revisão sistemática foi identificar o panorama dos artigos científicos publicados a partir do ano 2000 sobre a temática do ensino e da análise de jogo do goleiro de handebol.

\section{MÉTODO}

Esta revisão sistemática foi construída a partir de uma série de procedimentos metodológicos, como a definição dos critérios de inclusão para os estudos, um método de revisão que fosse claro e que pudesse ser reproduzido, assim como a avaliação rigorosa da relação entre os critérios estabelecidos e os estudos encontrados. Por fim, a apresentação sistemática dos estudos que foram incluídos ao final da pesquisa (HIGGINS; GREEN, 2008).

Para a realização desta revisão sistemática foram consultadas diversas bases de dados online que agrupam uma grande quantidade de trabalhos acadêmicos, que se constituem como as fontes mais confiáveis para se utilizar na construção de uma revisão sistemática (Prieto, 
Gómez e Sampaio, 2015). Nesta revisão, foram acessadas as seguintes bases de dados: Scielo, Web of Science, EBSCOHost (considerando aqui apenas a base SPORTDiscus), Lilacs, Redalyc, Scopus e Medline. Os termos descritores utilizados foram "goleiro" AND "handebol" para a língua portuguesa, "goalkeeper" AND "handball" para a língua inglesa e "portero" AND "balonmano" para a língua espanhola. Estes descritores foram pesquisados nos campos de busca "título", "palavras-chave" e "resumo" de cada base de dados.

As pesquisas nas bases de dados foram feitas nos três idiomas supracitados e cada um deles apresenta uma justificativa diferente. Os descritores em português foram utilizados para verificar a existência de trabalhos que pudessem mostrar as possibilidades de ação na formação dos goleiros de handebol no contexto brasileiro. Os descritores em inglês foram utilizados por se tratar do principal idioma de comunicação científica, sendo que a maioria dos artigos são publicados nesse idioma (VOLPATO, 2011; PRIETO; GÓMEZ; SAMPAIO, 2015). Já os descritores em espanhol se justificam pelo fato da Espanha ser um dos países com maior produção científica no handebol (PRIETO; GÓMEZ; SAMPAIO, 2015), atrelado à sua tradicional escola do esporte.

Definidas as bases de dados e os descritores em cada idioma, buscou-se estabelecer os critérios de pesquisa e de inclusão dos trabalhos na amostra desta revisão sistemática, assim constituídos:

1. publicações a partir de Jan/2000 até Dez/2017;

2. artigos originais com texto completo online, publicados em revistas indexadas nas bases de dados selecionadas previamente em um dos três idiomas supracitados;

3. artigos que tinham como temática os aspectos relacionados ao ensino/formação do goleiro de handebol e/ou aspectos relacionados à análise de jogo do respectivo posto específico.

No Quadro 1 está apresentado um resumo do número de trabalhos encontrados nas buscas feitas nas bases de dados a partir dos descritores e dos critérios de inclusão e exclusão definidos para o estudo. 
Quadro 1: Artigos encontrados na busca inicial em diferentes bases de dados e posteriores fases de seleção

\begin{tabular}{|c|c|c|c|c|c|}
\hline \multicolumn{2}{|c|}{$\begin{array}{l}\text { Artigos encontrados nas } \\
\text { buscas: }\end{array}$} & \multirow{2}{*}{$\begin{array}{c}\text { Artigos } \\
\text { incompletos / } \\
\text { Não } \\
\text { contemplou } \\
\text { o tema dos } \\
\text { descritores }\end{array}$} & \multirow{2}{*}{$\begin{array}{l}\text { Inseridos em } \\
\text { planilha } \\
\text { única }\end{array}$} & \multicolumn{2}{|c|}{ Seleção manual } \\
\hline Base de dados & $\begin{array}{c}\text { Procura } \\
\text { inicial }\end{array}$ & & & $\begin{array}{l}\text { Duplicados } \\
\text { na planilha } \\
\text { única }\end{array}$ & $\begin{array}{c}\text { Não } \\
\text { relacionado à } \\
\text { temática }\end{array}$ \\
\hline Scielo & 11 & 6 & 5 & \multirow{7}{*}{30} & \multirow{7}{*}{15} \\
\hline Web of Science & 109 & 85 & 24 & & \\
\hline EBSCOHost & 80 & 57 & 23 & & \\
\hline Lilacs & 34 & 31 & 3 & & \\
\hline Redalyc & 210 & 202 & 8 & & \\
\hline Scopus & 104 & 102 & 2 & & \\
\hline Medline & 13 & 1 & 12 & & \\
\hline TOTAL & 561 & 484 & 77 & 47 & 32 \\
\hline
\end{tabular}

Na busca inicial foram encontrados 561 ocorrências que foram separadas por base de dados. Os artigos que tiveram mais de uma ocorrência dentro da mesma base de dados, devido à busca em diferentes idiomas, foram computados apenas uma vez. A partir disso, esses artigos passaram por uma segunda fase de seleção, a partir dos seguintes critérios de exclusão: a) artigos duplicados nas buscas entre os três idiomas; b) artigos sem texto integral; c) artigos publicados em outros idiomas que não português; inglês e espanhol; d) artigos de revisão; e e) capítulos de livros, anais de congressos científicos e outros formatos que não artigo. Diante dos critérios adotados, foram excluídos 484 artigos, juntando as exclusões em todas as bases de dados pesquisadas.

Dos achados na busca inicial, restaram 77artigos que contemplavam os critérios de inclusão. Estes foram reorganizados em planilha única, sendo classificados pelo ano de publicação em ordem decrescente e pelo nome dos autores. Assim, foi possível excluir um total de 30 artigos que se repetiram em mais de uma base de dados, pelo fato de algumas revistas serem indexadas em mais de uma base. 
$\mathrm{Na}$ última fase de seleção dos artigos foram lidos os resumos dos 47 selecionados para verificar as relações com as temáticas desta revisão (ensino e análise de jogo do goleiro de handebol). Após a leitura dos resumos, quando a dúvida persistiu, o pesquisador procedeu a leitura do artigo completo. Ao final desta fase foram excluídos 15 artigos que, embora tenham investigado o goleiro de handebol, abordavam outras características, como as psicológicas, as avaliações dos esforços, as variáveis fisiológicas em contexto de jogo, as variações antropométricas e os padrões biomecânicos em diferentes ações de defesa.

Ao final do processo de seleção foram selecionados 32 artigos, dos quais foi realizada a análise dos dados bibliométricos (PRIETO; GÓMEZ; SAMPAIO, 2015), considerando os seguintes critérios: artigos publicados por ano, número de autores por artigo, países das universidades do primeiro autor, idioma de publicação e quantidade de artigos publicados sobre cada uma das temáticas centrais desta revisão sistemática, sendo o ensino e a análise de jogo do goleiro de handebol. Apesar da relação íntima entre treino e jogo (GARGANTA, 2009), o ensino e a análise de jogo são áreas de pesquisa com características diferentes, as quais podem abordar vários aspectos importantes e complementares. Optou-se, portanto, por separar os artigos por temática para identificar o panorama das publicações de cada área e as possíveis contribuições para a formação do goleiro handebol.

Posteriormente, partiu-se de uma abordagem qualitativa para analisar as temáticas centrais desta revisão, de acordo com os seguintes critérios: o subtema principal do trabalho (ensino ou análise de jogo), se os estudos tiveram ou não intervenção, a identificação da amostra/faixa etária, assim como das diferentes áreas de pesquisa contempladas nos estudos, analisando os métodos e as variáveis utilizadas. O objetivo dessa análise qualitativa foi identificar as características dos estudos e apontar as principais tendências de pesquisa. 


\section{RESULTADOS}

Na Figura 1 está apresentada a frequência de artigos publicados ao longo do período analisado (2000 a 2017).

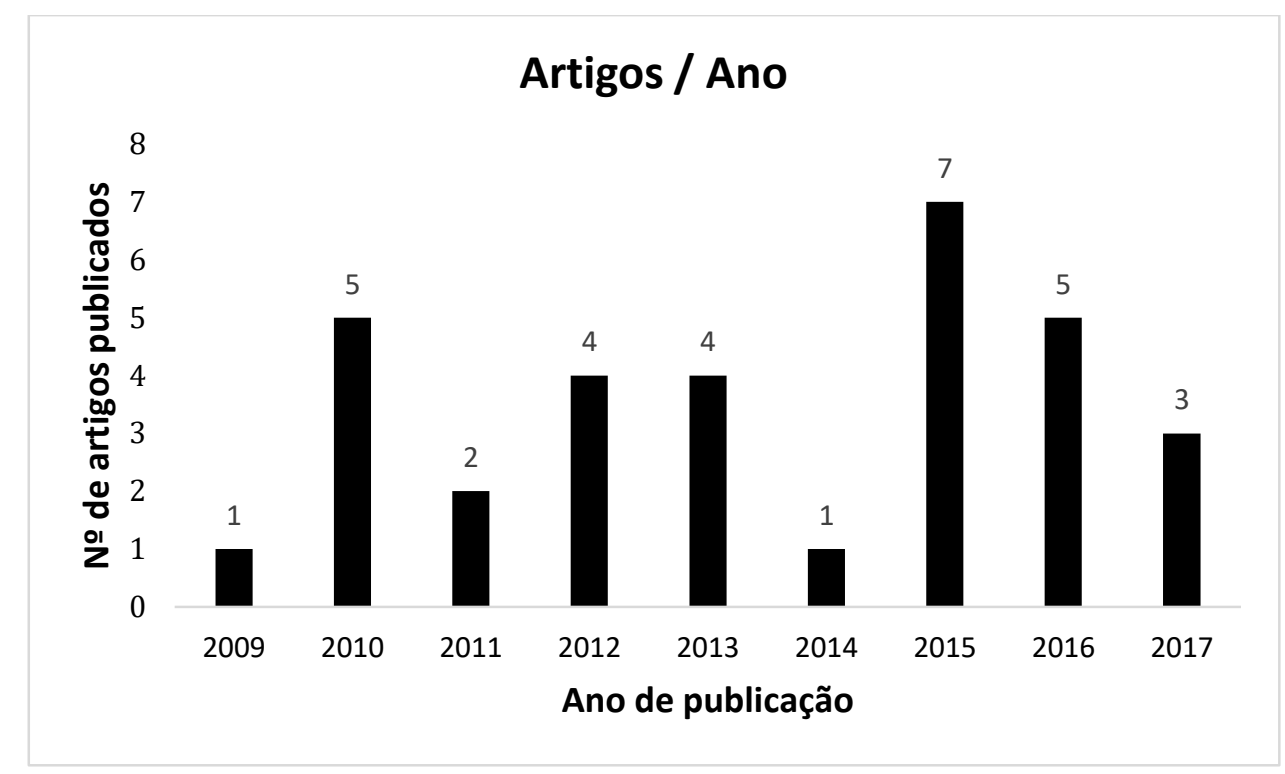

Figura 1. Número de artigos científicos publicados por ano.

Na Figura 2 está apresentado os resultados da análise do número de autores por artigo. A partir dessa informação, a Figura 3 apresenta a média de autores por artigo ao longo dos anos analisados.

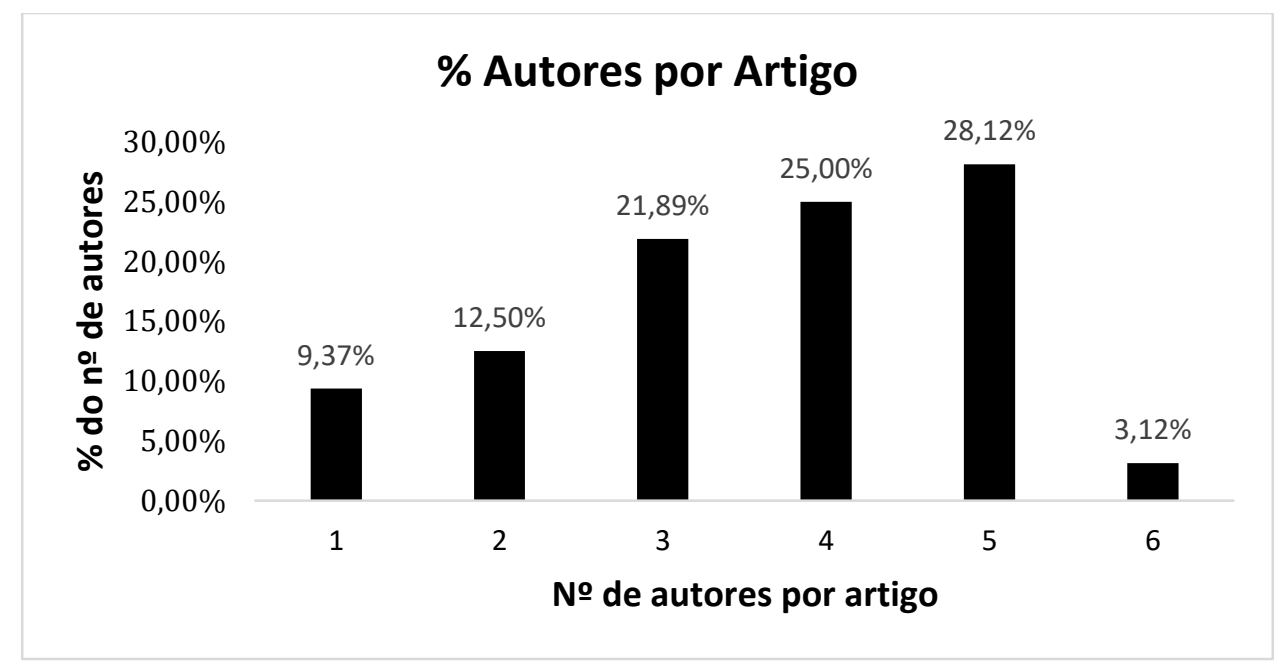

Figura 2. Porcentagem do número de autores por artigo. 


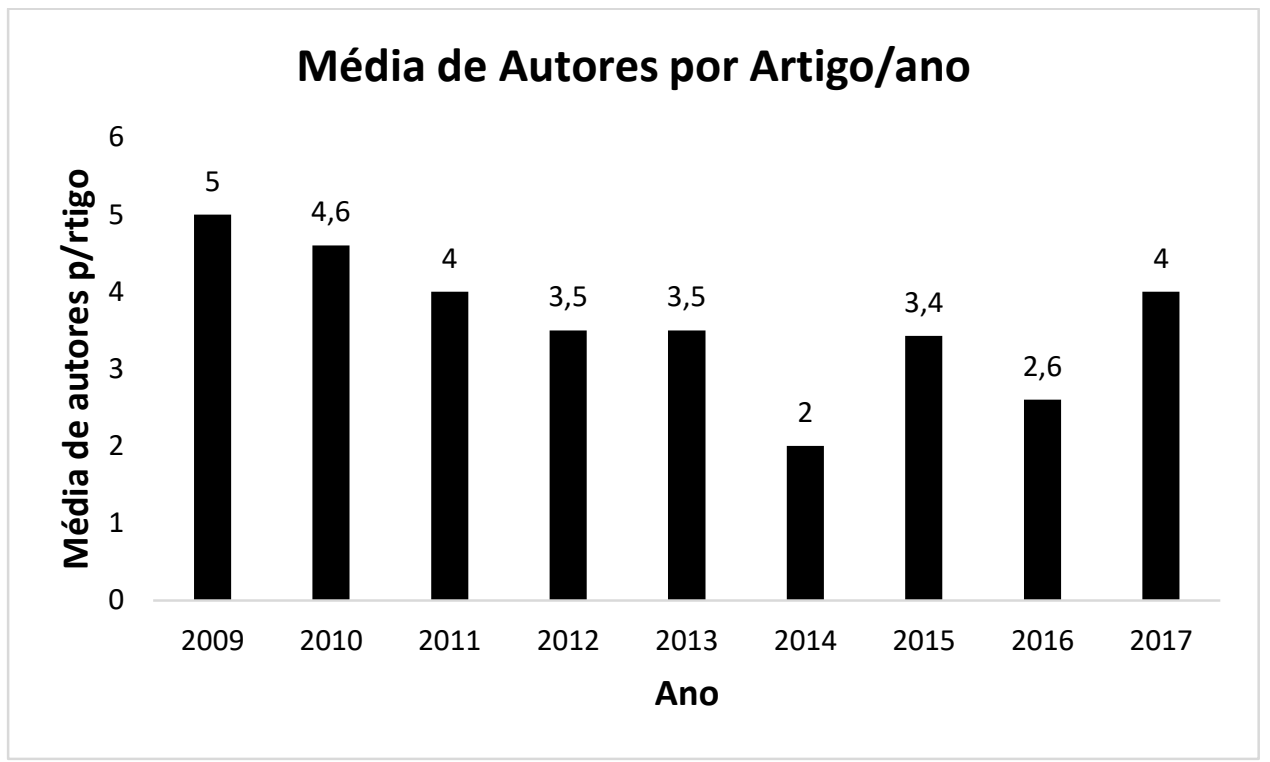

Figura 3. Média de autores por artigo ao longo do período observado

Na Figura 4 estão apresentados os países das universidades dos primeiros autores de cada artigo selecionado. A Figura 5 apresenta a porcentagem dos idiomas mais utilizados na escrita dos artigos que foram selecionados

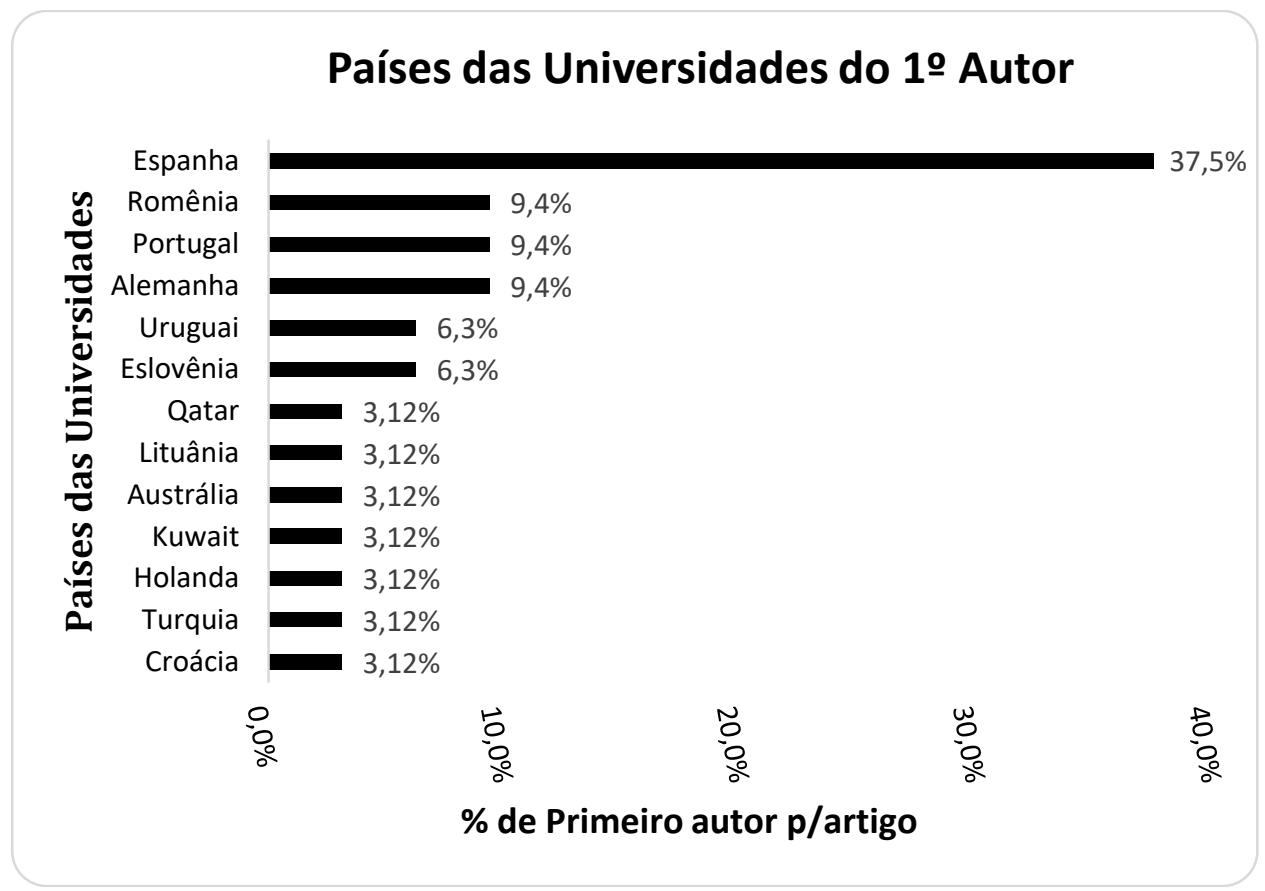

Figura 4. Percentual de publicações de acordo com os países das universidades. 


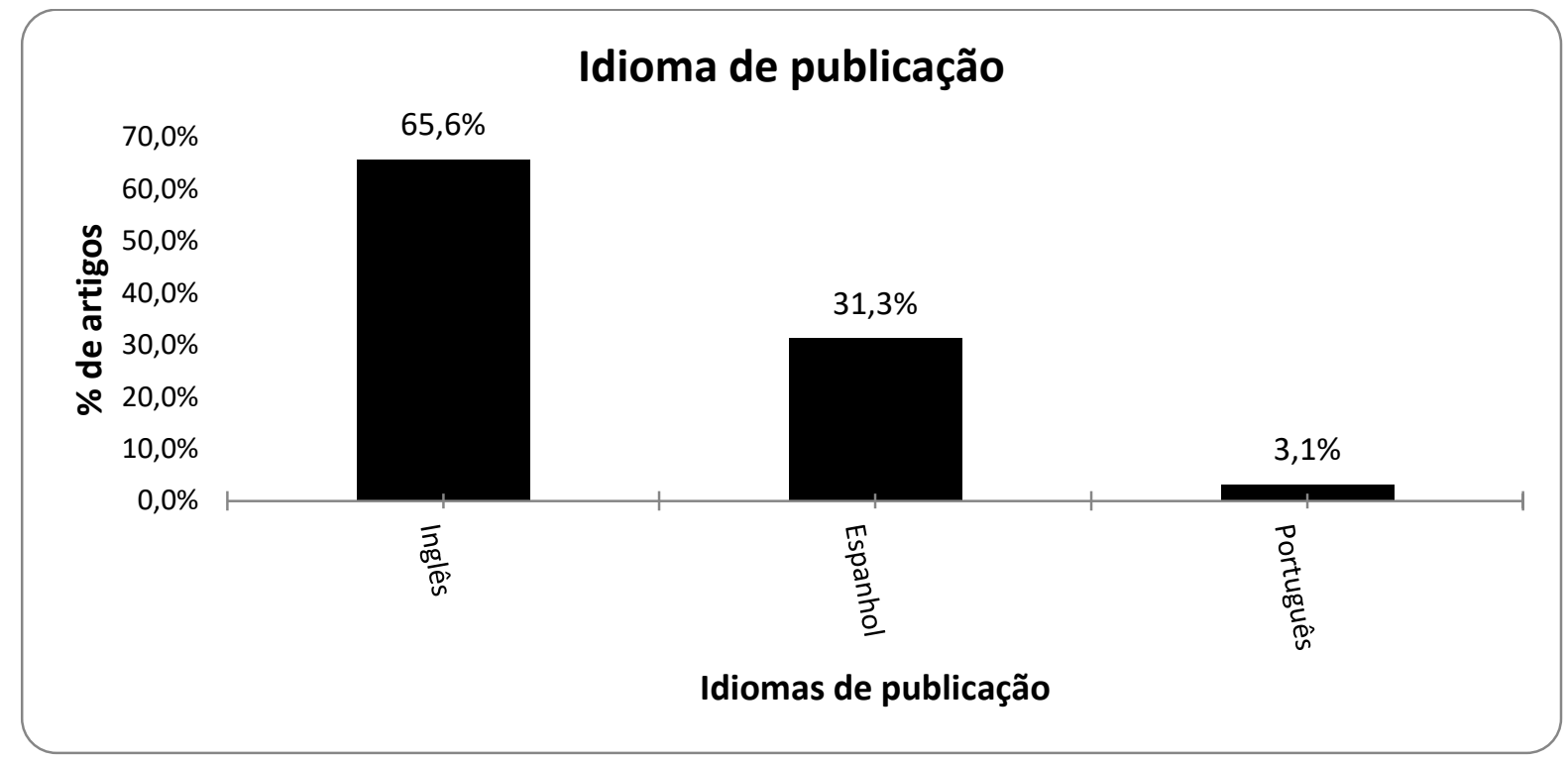

Figura 5. Percentual de publicações referentes ao idioma

Na figura 6 apresenta-se o número de artigos divididos entre as duas temáticas centrais desta revisão sistemática, o ensino e a análise de jogo do goleiro de handebol, no qual destacase maior frequência de pesquisas relacionadas à análise de jogo.

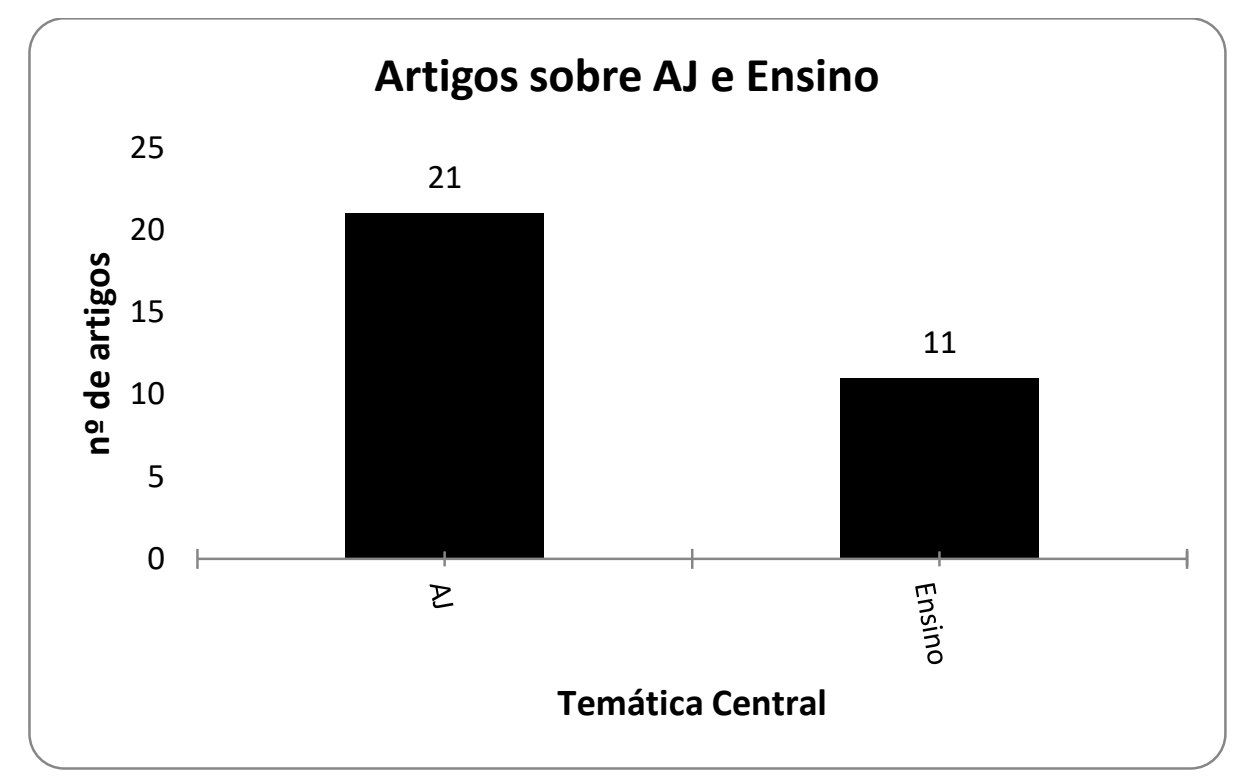

Figura 6. Quantidade de artigos sobre as temáticas de ensino e análise de jogo do goleiro de handebol 
DISCUSSÃO

O objetivo desta revisão sistemática foi identificar um panorama dos artigos sobre o ensino e a análise do goleiro de handebol. Nossos achados mostram que, após a seleção final dos 32 artigos originais, o interesse pelas temáticas pesquisadas nas bases consultadas ainda é recente. Considerando que a pesquisa teve um recorte temporal dos anos 2000 até 2017, o primeiro artigo que contemplou os critérios de inclusão só foi publicado em 2009 (ANTÚNEZ MEDINA et al., 2009).

A partir de 2010 nota-se aumento da produção de artigos, corroborando os achados de Prieto, Gómez e Sampaio (2015), porém tal aumento ocorre de forma irregular, alternado com períodos de diminuição na produção. Essa tendência parece se repetir atualmente, visto que nos anos de 2015 e 2016 foram publicados 12 artigos e em 2017 foram publicados apenas 3 artigos. Observa-se, de modo geral, que ao longo do tempo há um aumento do interesse da comunidade acadêmica em pesquisas sobre as temáticas de ensino e análise de jogo do goleiro de handebol.

Sobre o número de autores por artigo, observou-se um alto percentual em artigos com 3, 4 e 5 autores, representando $75 \%$ do analisado. No entanto, ao contrário do que se observou sobre o crescimento da produção acadêmica nestas temáticas, quando a análise se referiu à média de autores por artigo ao longo dos anos percebeu-se uma diminuição desse índice. Esse resultado difere dos achados de Prieto, Gómez e Sampaio (2015) e da maioria dos estudos da área de ciências do esporte (VALCÁRCEL et al., 2010).

Diante desses achados não é possível afirmar que há menos autores interessados, quando o número de publicações apresenta um aumento, porém a hipótese para este resultado pode estar relacionada com a formação de novos grupos de trabalho que investigam a temática em diferentes centros de pesquisa, e que possivelmente estejam iniciando as pesquisas em grupos menores. Tal hipótese pode ser sustentada a partir dos resultados encontrados sobre os países das universidades do primeiro autor, considerado como o principal (PRIETO, GÓMEZ, SAMPAIO, 2015). Os resultados apontaram que 37,5\% dos artigos selecionados foram produzidos na Espanha, que aparece como o país com maior percentual de estudos sobre as temáticas investigadas, demonstrando a tradição desse país no handebol. Ao todo, 13 países foram identificados, sendo nove europeus, dois asiáticos, um da Oceania e um sul-americano, refletindo a popularidade que o handebol tem no continente europeu. Destaca-se o fato de que 
não foram encontrados artigos originais do Brasil, considerando o país da universidade do autor principal, o que aponta uma lacuna na literatura brasileira sobre a formação do goleiro de handebol.

Em relação aos idiomas das publicações científicas, apesar de a Espanha ser o país com maior número de publicações desta revisão, a língua inglesa foi predominante $(65,6 \%)$, seguida pela espanhola (31,3\%). Esses achados reafirmam a posição do inglês como principal idioma referente às comunicações científicas (VOLPATO, 2011) e a necessidade e a importância das buscas também em língua espanhola, dada à tradição da Espanha no handebol. Destaca-se que apenas 3,1\% dos artigos foram publicados em língua portuguesa (provenientes de Universidades de Portugal), reforçando a lacuna no cenário brasileiro mencionada anteriormente, bem como o acesso a esse tipo de informação pelos treinadores do país.

Como as temáticas centrais desta revisão sistemática foram o ensino e a análise de jogo do goleiro de handebol, os 32 artigos selecionados foram subdivididos nessas duas categorias, totalizando 21 artigos sobre a análise de jogo e 11 artigos sobre o ensino do goleiro de handebol, cujos panoramas estão apresentados a seguir.

\section{ESTUDOS SOBRE ANÁLISE DE JOGO E O GOLEIRO DE HANDEBOL}

Wright, Carling e Collins (2014) entendem a análise de jogo como o estudo dos comportamentos (de jogadores e equipes) que ocorrem em jogo. Esses comportamentos podem ser identificados por meio de diversas variáveis de natureza técnica, tática, de preparação física e de preparação psicológica, seja em contexto de treino ou de jogo (MENEZES, REIS, 2010). Considerando a íntima relação entre treino e jogo (GARGANTA, 2009), os artigos que contemplaram a temática da análise de jogo do goleiro de handebol estão apresentados no Quadro 2.

Quadro 2. Características dos artigos sobre a temática de análise de jogo do goleiro de handebol

\begin{tabular}{|c|c|c|c|c|}
\hline Autor & $\begin{array}{c}\text { Tipo de } \\
\text { Pesquisa }\end{array}$ & Amostra/Categoria & Método & Variáveis Analisadas \\
\hline Hansen, Clint et al. (2017) & quantitativa & adulto masculino & $\begin{array}{c}\text { análise notacional com } \\
\text { vídeo das ações do } \\
\text { goleiro }\end{array}$ & $\begin{array}{c}\text { Eficácia do goleiro e suas } \\
\text { ações em jogo }\end{array}$ \\
\hline
\end{tabular}




\begin{tabular}{|c|c|c|c|c|}
\hline Ramírez A.G.,et al. (2017) & quantitativa & adulto masculino & análise observacional & Eficácia do goleiro em jogo \\
\hline Leuciuc et al., (2016) & quantitativa & adulto & estatística descritiva & Eficácia do goleiro em jogo \\
\hline González Ramírez (2016) & quantitativa & adulto & $\begin{array}{l}\text { análise notacional das } \\
\text { ações em jogo }\end{array}$ & $\begin{array}{l}\text { Eficácia do ataque de acordo } \\
\text { com as ações do goleiro }\end{array}$ \\
\hline $\begin{array}{c}\text { Espina-Agullo, Perez- } \\
\text { Turpin, Jimenez-Olmedo } \\
\text { (2016) }\end{array}$ & quantitativa & $\begin{array}{l}\text { adulto (32 finais } \\
\text { masculinas } \\
\text { internacionais) }\end{array}$ & $\begin{array}{c}\text { análise notacional com } \\
\text { vídeo e estatística } \\
\text { descritiva }\end{array}$ & Eficácia do Goleiro \\
\hline Teles, Volossovitch (2015) & quantitativa & adulto masculino & análise de vídeo & $\begin{array}{l}\text { Eficácia do goleiro e trabalho } \\
\text { com a defesa nos } 10 \text { minutos } \\
\text { finais }\end{array}$ \\
\hline Sousa et al., (2015) & quantitativa & adulto masculino & $\begin{array}{l}\text { análise notacional com } \\
\text { vídeo/ coordenadas } \\
\text { polares }\end{array}$ & $\begin{array}{l}2 \times 2 \text { - Eficácia do goleiro e } \\
\text { trabalho com a defesa }\end{array}$ \\
\hline Loffing et al., (2015) & quantitativa & $\begin{array}{l}\text { adulto masculino } \\
\text { (goleiros e não- } \\
\text { goleiros) }\end{array}$ & $\begin{array}{c}\text { análise observacional de } \\
\text { vídeo }\end{array}$ & $\begin{array}{l}\text { Desempenho em testes } \\
\text { perceptivos-motores }\end{array}$ \\
\hline Karpan et al., (2015) & quantitativa & adulto feminino & $\begin{array}{l}\text { aferição de FC pré e } \\
\text { durante jogo oficial, }\end{array}$ & $\begin{array}{c}\text { determinar as zonas de esforço } \\
\text { em partidas oficiais }\end{array}$ \\
\hline Calin (2015) & quantitativa & adulto masculino & $\begin{array}{l}\text { análise de documentos } \\
\text { com estatísticas de jogo }\end{array}$ & Eficácia do Goleiro \\
\hline Blanco et al., (2015) & quantitativa & adulto masculino & análise de vídeo & Eficácia do Goleiro \\
\hline $\begin{array}{l}\text { Skarbalius, Pukėnas, } \\
\text { Vidūnaitė (2013) }\end{array}$ & quantitativa & adulto masculino & $\begin{array}{l}\text { análise de documentos } \\
\text { com estatísticas de jogo }\end{array}$ & Eficácia do Goleiro \\
\hline $\begin{array}{l}\text { Rivilla-García, et al., } \\
\text { (2013) }\end{array}$ & quantitativa & adulto masculino & análise de vídeo & $\begin{array}{l}\text { informações visuais do } \\
\text { arremessador mais utilizadas } \\
\text { pelos goleiros (amador x pro) }\end{array}$ \\
\hline $\begin{array}{l}\text { Lago-Penas, Gomez, } \\
\text { Viano (2013) }\end{array}$ & quantitativa & adulto masculino & análise de vídeo & Eficácia do Goleiro \\
\hline $\begin{array}{l}\text { Foretic, Rogulj, Papic } \\
\qquad(2013)\end{array}$ & misto & adulto masculino & $\begin{array}{c}\text { análise de vídeo e } \\
\text { entrevista com experts } \\
\text { em handebol }\end{array}$ & Eficácia do Goleiro \\
\hline Javier Rojas et al., (2012) & quantitativa & $\begin{array}{c}7 \text { goleiros nacionais/ } \\
7 \text { não goleiros / } 4 \\
\text { jogadores linha } \\
\text { nacionais, adulto } \\
\text { masculino }\end{array}$ & análise cinemática & $\begin{array}{l}\text { características biomecânicas } \\
\text { do goleiro }\end{array}$ \\
\hline Bilge (2012) & quantitativa & adulto masculino & $\begin{array}{l}\text { análise de documentos } \\
\text { com estatísticas de jogo }\end{array}$ & Eficácia do Goleiro \\
\hline $\begin{array}{c}\text { Rivilla-García, Navarro } \\
\text { Valdivieso, Sampedro } \\
\text { (2011) }\end{array}$ & quantitativa & $\begin{array}{l}48 \text { jogadores } \\
\text { adultos } / 46 \text { jogadores } \\
\text { sub- } 18 \text { masculino }\end{array}$ & $\begin{array}{l}2 \text { testes: } 1 \text {-arremessos } \\
\text { de } 9 \text { m sem oposição do } \\
\text { goleiro 2- com oposição } \\
\text { do goleiro }\end{array}$ & $\begin{array}{l}\text { precisão dos arremessos com e } \\
\text { sem oposição do goleiro }\end{array}$ \\
\hline $\begin{array}{l}\text { Gutierrez-Davila, et al., } \\
\text { (2011) }\end{array}$ & quantitativa & $\begin{array}{c}7 \text { goleiros / } 4 \\
\text { jogadores de linha } \\
\text { masculino }\end{array}$ & análise biomecânica & $\begin{array}{c}\text { características biomecânicas } \\
\text { do goleiro }\end{array}$ \\
\hline $\begin{array}{l}\text { Antúnez Medina et al., } \\
\text { (2010a) }\end{array}$ & quantitativa & $\begin{array}{l}2 \text { goleiras adultas } \\
\text { nacionais }\end{array}$ & $\begin{array}{c}\text { aplicação de } \\
\text { treinamento e grupo } \\
\text { controle }\end{array}$ & Eficácia do Goleiro \\
\hline $\begin{array}{l}\text { Antúnez Medina et al., } \\
\qquad(2010 b)\end{array}$ & quantitativa & $\begin{array}{l}2 \text { goleiras adultas } \\
\text { nacionais }\end{array}$ & $\begin{array}{l}\text { aplicação de } \\
\text { treinamento e grupo } \\
\text { controle }\end{array}$ & Eficácia do Goleiro \\
\hline
\end{tabular}

Os resultados apontaram que 95,23\% dos artigos sobre análise de jogo do goleiro de handebol possuem abordagem quantitativa e 4,77\% (um estudo) apresentou abordagem 
mista. Em relação à intervenção dos estudos, 47,61 \% optaram por uma intervenção direta sobre a amostra a partir de diferentes métodos, enquanto 52,3\% não apresentaram algum tipo de intervenção.

Sobre a composição das amostras dos estudos, 80,95\% analisou atletas adultos masculinos, preferencialmente com experiência em nível nacional e/ou internacional. Também houve estudos com a presença da categoria adulta feminina (14,28\%), também com experiência em nível nacional e/ou internacional. A comparação entre goleiros experientes e não-goleiros (sem experiência prévia) também foi adotada em dois artigos (JAVIER ROJAS et al., 2012; LOFFING et al., 2015), com o objetivo de comparar o nível de experiência entre diferentes grupos. Chama-se a atenção para o fato de que não houve estudos com goleiros de categorias de formação, indicando a preferência pela categoria adulta e uma lacuna em relação aos jovens goleiros.

De maneira geral, a maioria dos estudos $(66,6 \%)$ centrou seu interesse na eficácia durante a competição e apoiou-se em diferentes métodos. O método de análise notacional foi o mais utilizado nos estudos selecionados, seja in loco ou a partir de vídeos dos jogos (HANSEN et al., 2017; RAMÍREZ et al., 2017). Outro tipo de análise se baseou nas súmulas e estatísticas oficiais da Federação Internacional de Handebol (IHF) (BILGE 2012; SKARBALIUS, PUKÉNAS, VIDUNAITÉ, 2013; CALÍN, 2015). De modo geral, entende-se que a alta eficácia do goleiro é importante para que a sua equipe tenha um bom desempenho, especialmente em situações como quando o jogo é em casa (LAGO-PEÑAS; GÓMEZ; VIANO, 2013), em relação aos tipos de arremesso (FORETIC; ROGULJ; PAPIC, 2013) e nos últimos 10 minutos de jogo (TELES; VOLOSSOVITCH, 2015).

Além dos estudos de eficácia outros assuntos se mostraram interessantes para os pesquisadores, como as análises biomecânicas do goleiro diante de arremessos de longa distância (9m). As principais considerações apontam que os goleiros experientes conseguem identificar o lado do arremesso de acordo com a trajetória dos atacantes e que assim que bola sai da mão do atacante, os goleiros experientes já conseguem identificar a altura do arremesso (JAVIER-ROJAS et al., 2012). Os artigos que utilizaram testes motores centraram seus interesses na capacidade perceptiva dos goleiros de identificar os estímulos relevantes para antecipar o resultado do arremesso, por meio de vídeos com arremessos de $7 \mathrm{~m}$. Os resultados dos estudos apontam que apesar de olharem normalmente para o mesmo estímulo, os goleiros 
experientes conseguem antecipar mais rápido e de forma mais precisa o arremesso (RIVILLAGARCIA et al., 2013).

Um dos artigos, voltado à análise de parâmetros fisiológicos, utilizou a frequência cardíaca e o tempo de jogo efetivo para determinar as zonas de esforço em cada um dos postos específicos do handebol (KARPAN et al., 2015). Percebeu-se que os goleiros passam a maior parte do jogo em zonas de esforço moderado, porém as ações de defesa estão concentradas em zonas de esforço máximo.

Nos artigos selecionados sobre análise de jogo do goleiro de handebol foi observada uma predominância na utilização de abordagens quantitativas de pesquisa. Diversos aspectos são analisados nos estudos, contribuindo para a compreensão de diversos aspectos relacionados com a formação, com o treinamento do goleiro e com a quantificação do seu desempenho. Em contrapartida, há uma escassez de trabalhos com abordagem qualitativa, que também poderiam contribuir para o desenvolvimento das pesquisas sobre o goleiro de handebol.

\section{ESTUDOS SOBRE ENSINO DO GOLEIRO DE HANDEBOL}

O goleiro de handebol é um posto específico que pode influenciar o resultado de uma partida e tem em seu processo de formação diversos aspectos como a sua posição-base, as técnicas de defesa e a sua concentração em jogo, que são alguns exemplos de suas características a serem treinadas para que se atinja um bom nível de desempenho (ARIAS ESTERO, 2009; PASCUAL FUERTES; LAGO PEÑAS; CASÁIS MARTINEZ; 2010).

Considerando a inexorável relação entre ensino e treino (GRECO, 2001), é fundamental conhecer as características do posto específico em cada etapa da formação dos goleiros em diferentes faixas etárias/níveis de rendimento (SÁ et al., 2015). Desse modo será possível sistematizar o treinamento para estimular os goleiros a desenvolver as capacidades necessárias para um bom desempenho durante as situações apresentadas no jogo (GRECO, 2001).

Os achados desta pesquisa revelaram um número escasso de trabalhos quando comparados com outras revisões no handebol (AGUILAR, 2014; PRIETO, GÓMEZ, SAMPAIO, 2015), sendo o ensino uma temática ainda pouco explorada pela literatura. No Quadro 3 estão apresentadas as características dos artigos incluídos na amostra. 
Quadro 3. Características dos artigos sobre a temática de ensino do goleiro de handebol

\begin{tabular}{|c|c|c|c|c|}
\hline Autor & $\begin{array}{l}\text { Tipo de } \\
\text { Pesquisa }\end{array}$ & Amostra/Categoria & Método & $\begin{array}{c}\text { Variáveis } \\
\text { Analisadas }\end{array}$ \\
\hline $\begin{array}{l}\text { Cătălin, Popescu Mihai, } \\
\text { Ion, Mihaila (2017) }\end{array}$ & quantitativo & adulto masculino & aplicação de treinamento & $\begin{array}{c}\text { efeitos do } \\
\text { treinamento em } \\
\text { diferentes variáveis }\end{array}$ \\
\hline $\begin{array}{l}\text { Helm, Reiser, Munzert } \\
\text { (2016) }\end{array}$ & quantitativa & $\begin{array}{l}15 \text { goleiros adultos / } \\
15 \text { não goleiros }\end{array}$ & $\begin{array}{l}\text { testes de tempo de reação em } \\
\text { tarefas específicas e não } \\
\text { específicas }\end{array}$ & $\begin{array}{l}\text { Desempenho em } \\
\text { testes perceptivos- } \\
\text { motores }\end{array}$ \\
\hline Alsharji, Wade (2016) & quantitativa & $\begin{array}{l}21 \text { goleiros adultos / } \\
21 \text { goleiros sub18 }\end{array}$ & video de cobranças de $7 \mathrm{~m}$ & $\begin{array}{l}\text { Desempenho em } \\
\text { testes perceptivos- } \\
\text { motores }\end{array}$ \\
\hline Sá et al., (2015) & qualitativa & $\begin{array}{l}8 \text { goleiros de nível } \\
\text { internacional - Liga } \\
\text { ASOBAL }\end{array}$ & entrevista semi-estruturada & $\begin{array}{l}\text { características dos } \\
\text { goleiros }\end{array}$ \\
\hline $\begin{array}{l}\text { Loffing, Hagemann } \\
\text { (2014) }\end{array}$ & quantitativa & $\begin{array}{l}\text { Exp1: } 9 \text { goleiros e } 5 \\
\text { goleiras experientes; } \\
17 \text { não-goleiros e } 6 \\
\text { não-goleiras; Exp2: } \\
20 \text { goleiros } \\
\text { experientes e } 20 \text { não } \\
\text { goleiros }\end{array}$ & $\begin{array}{l}2 \text { experimentos de vídeos com } \\
\text { arremessos de } 7 \mathrm{~m} \text { metros }\end{array}$ & $\begin{array}{l}\text { Desempenho em } \\
\text { testes perceptivos- } \\
\text { motores }\end{array}$ \\
\hline Pori et al., (2012) & quantitativa & $\begin{array}{l}46 \text { goleiros adultos } \\
\text { nacionais }\end{array}$ & $\begin{array}{c}\text { Bateria de testes motores e } \\
\text { avaliação da performance } \\
\text { técnica }\end{array}$ & $\begin{array}{l}\text { Desempenho em } \\
\text { testes perceptivos- } \\
\text { motores }\end{array}$ \\
\hline Abernethy et al., (2012) & misto & $\begin{array}{l}31 \text { não-goleiros e } 29 \\
\text { não-goleiras }\end{array}$ & $\begin{array}{c}\text { Aferir a capacidade de } \\
\text { percepção dos goleiros em } \\
\text { arremessos diante diferentes } \\
\text { tipos de feedback }\end{array}$ & $\begin{array}{c}\text { efeitos do } \\
\text { treinamento em } \\
\text { diferentes variáveis }\end{array}$ \\
\hline $\begin{array}{c}\text { Cañal-Bruland, van der } \\
\text { Kamp, van Kesteren } \\
\text { (2012) }\end{array}$ & quantitativa & $\begin{array}{l}26 \text { jogadores de linha } \\
\text { experientes; } 19 \\
\text { goleiros experientes; } \\
20 \text { não-goleiros }\end{array}$ & $\begin{array}{l}\text { teste de vídeo para antecipar o } \\
\text { resultado dos arremessos de } \\
7 \mathrm{~m}\end{array}$ & $\begin{array}{l}\text { Desempenho em } \\
\text { testes perceptivos- } \\
\text { motores }\end{array}$ \\
\hline $\begin{array}{l}\text { Antúnez Medina et al., } \\
\text { (2010) }\end{array}$ & quantitativa & $\begin{array}{l}1 \text { goleira nacional } \\
\text { adulta }\end{array}$ & $\begin{array}{c}\text { aplicação de treinamento } \\
\text { perceptivo-motor e avaliação } \\
\text { do mesmo }\end{array}$ & $\begin{array}{c}\text { efeitos do } \\
\text { treinamento em } \\
\text { diferentes variáveis }\end{array}$ \\
\hline $\begin{array}{l}\text { Antúnez Medina et al., } \\
\text { (2010) }\end{array}$ & quantitativa & $\begin{array}{l}2 \text { goleiras nacionais } \\
\text { adultas }\end{array}$ & $\begin{array}{l}\text { aplicação de treinamento e } \\
\text { grupo controle }\end{array}$ & $\begin{array}{c}\text { efeitos do } \\
\text { treinamento em } \\
\text { diferentes variáveis }\end{array}$ \\
\hline $\begin{array}{l}\text { Antúnez Medina et al., } \\
\qquad(2009)\end{array}$ & quantitativa & $\begin{array}{l}2 \text { goleiras nacionais } \\
\text { adultas }\end{array}$ & $\begin{array}{l}\text { aplicação de treinamento e } \\
\text { grupo controle }\end{array}$ & $\begin{array}{c}\text { efeitos do } \\
\text { treinamento em } \\
\text { diferentes variáveis }\end{array}$ \\
\hline
\end{tabular}

Dos estudos selecionados nesta temática, $72,7 \%$ adotaram abordagem quantitativa, $9,1 \%$ abordagem qualitativa e $18,2 \%$ abordagem mista. Os estudos quantitativos apresentaram diversos tipos de intervenções, desde a aplicação de testes motores e aplicação de um tipo de treino e a sua comparação com um grupo controle em relação ao resultado desse treino. O estudo qualitativo, utilizou uma entrevista semi-estruturada feita com atletas (SÁ et al., 2015) e o estudo misto baseou-se na aplicação de uma proposta de treino em conjunto com um questionário (ABERNETHY et al., 2012). 
Em relação à composição das amostras dos estudos selecionados observou-se uma preferência pela categoria adulta masculina, com experiências de atuação no alto nível do handebol, tendo disputado competições nacionais e internacionais $(81,8 \%)$. Essa preferência pode estar relacionada ao fato de representarem o mais alto nível competitivo, o qual torna-se referência sobre as habilidades e sobre os processos que os levaram até o alto rendimento, servindo de parâmetros para as categorias mais jovens (SÁ et al., 2015) assim como apontado nos estudos sobre análise de jogo. Alguns dos estudos selecionados também apresentaram a divisão em grupos de goleiros experientes e grupos de "não-goleiros", sem experiência prévia (CAÑAL-BRULAND, VAN DER KAMP, VAN KESTEREN, 2010; LOFFING, HAGEMANN, 2014). A experiência é apontada como uma das razões em conjunto com o tempo de prática, que explicam a melhora do rendimento do goleiro em competição (SÁ et al., 2015).

Destaca-se que apenas três estudos utilizaram uma amostra composta pela categoria adulta feminina comparando as goleiras que atuavam a nível nacional e internacional (ANTÚNEZ MEDINA, 2009; 2010a; 2010b). Estudos como os de Loffing e Hagemann (2014) e Abernethy et al. (2012) utilizaram amostras masculinas e femininas, comparando o nível de experiência na execução de diferentes tarefas. Apesar da pouca presença de estudos com goleiras, os resultados das variáveis analisadas não apontou diferenças entre o sexo masculino e feminino (LOFFING, HAGEMANN, 2014), mas que a qualidade do processo de ensino dos goleiros que determina o desempenho em situação de jogo.

Apenas um estudo enfatizou as categorias de formação. Alsharji e Wade (2016) compararam a percepção e a antecipação em tiros de $7 \mathrm{~m}$ entre goleiros adultos e um grupo de goleiros da categoria sub-18 a partir de vídeos, nos quais os goleiros deveriam indicar as informações que consideravam importantes para antecipar as ações do atacante no momento da cobrança.

A partir dos resultados encontrados verificou-se uma lacuna nos estudos com goleiros jovens. Apesar disso, existem alguns trabalhos de revisão que discutiram alguns temas sobre o treinamento com goleiros jovens. A revisão feita por Gómez (2007) procurou apresentar propostas de treinamento do goleiro de handebol para as categorias jovens. Já Romero Novoa (2012), ao fazer uma revisão sobre as capacidades de percepção e antecipação do goleiro de handebol, apresentou propostas de exercícios direcionados para as categorias jovens. Em ambos 
os trabalhos foi destacado que o treinamento do goleiro deve ser adequado para a faixa etária correspondente e não somente uma reprodução do que se faz na categoria adulta (GÓMEZ, 2007; ROMERO NOVOA, 2012).

Os artigos selecionados nesta pesquisa investigaram três grandes grupos de variáveis: o desempenho em testes motores, as características dos goleiros e os efeitos do treinamento em diferentes variáveis do desempenho. Nos artigos que avaliaram o desempenho em testes motores, os métodos mais utilizados foram testes de vídeo para a percepção dos sinais relevantes na antecipação do resultado de uma cobrança de $7 \mathrm{~m}$ pelos goleiros (ALSHARJI, WADE, 2016; LOFFING, HAGEMANN, 2014; CAÑAL-BRULAND, VAN DER KAMP, VAN KESTEREN, 2010). Alguns artigos utilizaram baterias de testes motores para estabelecer uma relação entre esses e a capacidade técnica dos goleiros (PORI et al., 2012), comparando as diferenças entre goleiros experientes e novatos (HELM; REISER; MUNZERT, 2016).

No caso dos testes motores, os resultados encontrados apontaram que não houve uma relação direta entre esses e a capacidade técnica dos goleiros de handebol, sugerindo que outras características como a capacidade de percepção e antecipação podem influenciar no seu desempenho (PORI et al., 2012). Outro resultado encontrado foi o de que o tempo de reação dos goleiros melhora, quanto melhor for o seu repertório motor e sua capacidade de perceber os estímulos relevantes da ação do atacante em posse de bola (HELM; REISER; MUNZERT, 2016).

Em relação aos testes de vídeo, foram utilizados em uma situação específica como a cobrança de $7 \mathrm{~m}$ e, nesse caso, confirmaram o que foi sugerido nos estudos com testes motores: há uma íntima ligação entre a qualidade do repertório motor e a capacidade de perceber os estímulos relevantes da situação de jogo no desempenho dos goleiros em antecipar mais rápido e com maior precisão o resultado das cobranças de $7 \mathrm{~m}$, especialmente as cobranças diretas, mas com melhora destacada também nas cobranças com fintas dos atacantes (ALSHARJI, WADE, 2016; LOFFING, HAGEMANN, 2014; CAÑAL-BRULAND, VAN DER KAMP, VAN KESTEREN, 2010) . Pelas razões apresentadas é destacada a importância da construção de experiências em longo prazo (LOFFING, HAGEMANN, 2014).

Os artigos apresentados sugerem que deve haver um treinamento de habilidades motoras específicas com os goleiros (HELM; REISER; MUNZERT, 2016) e também um treinamento de capacidades como a percepção e antecipação pautando-se nos movimentos dos 
atacantes no momento do arremesso (ALSHARJI, WADE, 2016; LOFFING, HAGEMANN, 2014).

Sobre os artigos que pesquisaram o efeito do treinamento em diferentes variáveis, três artigos de um mesmo grupo de autores (ANTÚNEZ MEDINA et al., 2009; 2010a; 2010b) aplicaram uma proposta de treinamento da capacidade de percepção do goleiro de handebol, diante de diferentes estímulos, em situação de jogo. Os resultados apontaram que o treinamento perceptivo aplicado foi importante para a melhora do desempenho das goleiras em situação de jogo. Já no artigo mais recente sobre a temática, foi desenvolvido uma proposta de sistematização do treinamento de equilíbrio para o goleiro de handebol (CATALIN, MIHAILA, 2017). O artigo apontou que o treinamento dessa capacidade deve ser feito de maneira individualizada pelo goleiro, buscando inserir elementos técnico-táticos nos exercícios para que se aproximem da situação real de jogo.

Em relação ao tema das características dos goleiros de handebol, houve apenas o artigo de Sá et al. (2015) que realizou uma entrevista semi-estruturada com goleiros de handebol de nível internacional, para identificar as características importantes para a sua formação e para a atuação em alto nível. A síntese dos resultados aponta a importância da interação entre o treinamento de diferentes capacidades físicas, técnico-táticas e psicológicas desde que seja feita pelo prazer da criança, motivando-a a continuar a treinar como goleiro (SÁ et al., 2015). Sobre esse aspecto, o trabalho de revisão feito por Muñoz Moreno et al. (2012), que pesquisou diversas propostas de treinamento para o goleiro de handebol, corrobora os achados apresentados anteriormente, os quais apontam uma interação entre as capacidades desenvolvidas adequadas de acordo com a faixa etária.

\section{CONSIDERAÇÕES FINAIS}

Após a busca pelos artigos nas bases de dados e a seleção final de 32 artigos originais, verificou-se que o interesse pela temática é recente (com o primeiro estudo publicado em 2007), sugerindo que há um vasto campo a ser explorado.

Percebeu-se que houve um crescimento na produção científica sobre essas temáticas do goleiro de handebol, especialmente a partir de 2010. Além disso, os resultados apontam para uma possível disseminação de novos grupos de trabalho em vários países. Todavia, foi verificada uma hegemonia espanhola na produção acadêmica sobre o goleiro de 
handebol, mesmo com o inglês ainda sendo o principal idioma utilizado, corroborando com trabalhos anteriores (AGUILAR, 2014; PRIETO, GÓMEZ, SAMPAIO, 2015). Há, sobretudo na literatura brasileira, uma lacuna referente a publicação de artigos originais sobre a formação do goleiro de handebol.

Observou-se resultados semelhantes para as duas áreas de interesse (análise de jogo / ensino), relacionadas à preferência pela pesquisa quantitativa e atletas adultos de alto nível. Dessa forma, há duas importantes lacunas: as pesquisas com atletas de categorias jovens e as pesquisas com os treinadores. A primeira lacuna se dá pela preferência por atletas adultos de alto nível, o que pode levar à reprodução de modelos de treinamento adultos com jovens atletas em busca de resultados rápidos, sem que haja um planejamento a longo prazo para a formação desses. A segunda lacuna se dá pelo fato de não investigar a opinião dos treinadores, uma vez que irão atuar na prática com os atletas e são importantes personagens no processo de formação esportiva.

Espera-se que esta revisão sistemática possa ser utilizada por pesquisadores para suscitar problemas relacionados às categorias jovens, estimulando o crescimento das pesquisas que envolvam a formação dos goleiros considerando as diferentes faixas etárias, bem como o desenvolvimento de pesquisas que possam integrar a opinião dos treinadores às perspectivas de ensino e análise de jogo do goleiro de handebol.

Como limitação do estudo aponta-se que existem revistas e jornais científicos que não estão indexados nas bases de dados pesquisadas, dessa forma alguns artigos podem não ter sido incluídos na amostra desta revisão sistemática.

\section{REFERÊNCIAS}

ABERNETHY, B. et al. Perceptual training methods compared: The relative efficacy of different approaches to enhancing sport-specific anticipation.. Journal Of Experimental Psychology: Applied, v. 18, n. 2, p.143-153, 2012.

AGUILAR, Ó.G. Análisis de la producción científica en balonmano en las revistas de la Web of Science. E-balonmano.com: Journal of Sport Science, v.10, n.2, p.77-88, 2014.

ALSHARJI, K.; WADE, M. Perceptual training effects on anticipation of direct and deceptive 7-m throws in handball. Journal Of Sports Sciences, v. 34, n. 2, p.155-162, 28 abr. 2015. 
ANTÚNEZ MEDINA, A. La interceptación en la portera de balonmano: efectos de un programa de entrenamiento perceptivo-motriz, 2003. 360 f. Tese (Doutorado) -, Universidad de Murcia, Murcia, Espanha, 2003.

ANTÚNEZ MEDINA, A. et al. Efecto de un programa de entrenamiento perceptivo-motor sobre la eficacia global de la portera de balonmano en competición. Cuadernos de Psicología del Deporte, Murcia, Espanha, v. 9, n. 2, p.31-43, 2009.

ANTÚNEZ MEDINA, A. et al. Repercusión de un programa de entrenamiento perceptivomotor sobre la eficacia en competición de la portera de balonmano según el tipo de lanzamiento. E-balonmano- Revista de Ciencias del Deporte, Murcia, Espanha, v. 3, n. 6, p.123-140, 2010a.

ANTÚNEZ MEDINA, A. et al. Programa de Entrenamiento Perceptivo-Motor para mejorar la efectividad de la portera de balonmano. Revista de Psicología del Deporte, Barcelona, Espanha, v. 19, n. 1, p.151-165, 2010 b.

ARIAS ESTERO, J.L. El Portero de Balonmano. Revista Internacional de Deportes Coletivos, Madrid, v.4, p.14-34, 2009.

BILGE, M.. Game Analysis of Olympic, World and European Championships in Men's Handball. Journal Of Human Kinetics, v. 35, n. 1, p.109-118, 2012.

CALÍN, R. The contribution of the goalkeepers of the france national team in winning the international handball competitions. Science, Movement And Health. Romênia, p. 57-61. 2015 .

CAÑAL-BRULAND, R.; KAMP, J. van Der; VAN KESTEREN, J.. An examination of motor and perceptual contributions to the recognition of deception from others' actions. Human Movement Science, v. 29, n. 1, p.94-102, fev. 2010.

CĂTĂLIN, P. M.; ION, M.. Contributions to developing the balance ability to players handball performance specializing as a goalkeeper. Journal Of Physical Education And Sport, [s.1.], v. 17, n. 05, p. $2270-2273,24$ nov. 2017.

ESPINA-AGULLÓ, J. J. et al. Effectiveness of Male Handball Goalkeepers: a historical overview 1982-2012. International Journal Of Performance Analysis In Sport. Alicante, Espanha, p. 143-156. abr. 2016.

FERNÁNDEZ-RIOS, L.; BUELA-CASAL, G. Standards for the preparation and writing of Psychology review articles. International Journal Of Clinical And Health Psychology, p. 329-344. 2009.

FORETIC, N.; ROGULJ, N.; PAPIC, V.. Empirical model for evaluating situational efficiency in top level handball. International Journal Of Performance Analysis In Sport, n. 13, p. 275293, 2013. 
GALVÃO, T. F.; PANSANI, T. S. A.; HARRAD, D.. Principais itens para relatar Revisões sistemáticas e Meta-análises: A recomendação PRISMA. Epidemiologia e Serviços de Saúde, v.24, n.2, p.335-342, 2015.

GARGANTA, J. Trends of tactical performance analysis in team sports: bridging the gap between research, training and competition. Revista Portuguesa de Ciências do Desporto, Porto, v.9, n.1, p.81-89, 2009.

GÓMEZ, R. A. El entrenamiento del portero de balonmano en las etapas de iniciación. Ebalonmano - Revista de Ciencia del Deporte, Espanha, v. 2, n. 3, p.21-32, 2007

GRECO, P.J. Métodos de ensino-aprendizagem-treinamento nos jogos esportivos coletivos. In: Temas Atuais VI em Educação Física e Esportes. GARCIA, E.S.; LEMOS, K.L.M. Belo Horizonte: Saúde Ltda., 2001, Cap.3, pp.48-72.

HANSEN, C. et al. Performance analysis of male handball goalkeepers at the WorldHandball championship 2015. Biology Of Sport, [s.1.], v. 34, n. 4, p.393-400, 2017.

HELM, F.; REISER, M.; MUNZERT, J.. Domain-Specific and Unspecific Reaction Times in Experienced Team Handball Goalkeepers and Novices. Frontiers In Psychology, v. 7, p.1-11, 21 jun. 2016

HIGGINS, J.; GREEN, S. - editors. Cochrane handbook for systematic reviews of interventions. West Sussex: John Wiley \& Sons Ltd, 2008.

JAVIER ROJAS, F. et al. Biomechanical analysis of anticipation of elite and inexperienced goalkeepers to distance shots in handball. Journal Of Human Kinetics, v. 34, n. 1, p.41-48, 1 jan. 2012.

KARPAN, G. et al. Analysis of female handball players' effort in different playing positions during official matches. Kinesiology, Ljubljana, v. 1, n. 47, p.100-107, 2015.

LAGO-PEÑAS, C. et al. Home advantage in elite handball: the impact of the quality of opposition on team performance. International Journal Of Performance Analysis In Sport, n. 13, p.724-733, 2013.

LOFFING, F.; HAGEMANN, N.. Skill differences in visual anticipation of type of throw in team-handball penalties. Psychology Of Sport And Exercise, v. 15, n. 3, p.260-267, maio 2014.

LOFFING, F. et al. Accuracy of Outcome Anticipation, But Not Gaze Behavior, Differs Against Left- and Right-Handed Penalties in Team-Handball Goalkeeping. Frontiers In Psychology, v. 6, p.1-11, 2015. Frontiers Media SA. 
MENEZES, R.P.; REIS, H.H.B. Análise do jogo de handebol como ferramenta para sua compreensão técnico-tática. Motriz, v.16, n.2, p.458-467, 2010.

MUÑOZ MORENO, A. et al. Análisis de los diferentes modelos de entrenamiento para porteros de balonmano. E-balonmano - Revista de Ciencia del Deporte, Espanha, v. 8, n. 3, p.223$232,2012$.

PASCUAL FUERTES, X; LAGO PEÑAS, C.; CASÁIS MARTINEZ, L.; La influencia de la eficacia del portero en el rendimiento de los equipos de balonmano. Apunts: Educación Física y Deportes, Catalunya, Espanha, n. 99, p.72-81, fev. 2010. Disponível em: <http://www.revista-apunts.com/es/hemeroteca?article=1411>. Acesso em: 8 dez. 2016.

PORI, P. et al. Correlation between the motor abilities and competitive performance of slovenian handball goalkeepers. Kinesiologia Slovenica, Ljubljana, v.2, n.18, p.19-26, 2012.

PRIETO, J.; GÓMEZ, M.A.; SAMPAIO, J. A bibliometric review of the scientific production in handball. Cuadernos de Psicología del Deporte, Murcia, v.15, n.3, p.145-154, 2015.

RAMÍREZ, A. G. et al. Eficacia de los porteros en los Juegos ODESUR y Campeonato Panamericano de Balonmano en 2014. Apunts Educación Física y Deportes, [s.1.], n. 130, p.95-105, 30 nov. 2017.

RIVILLA-GARCIA, J. et al. A comparative analysis of visual strategy in elite and amateur handball goalkeepers. Journal Of Human Sport And Exercise, v. 8, n. 3, p.743-753, 2013.

ROMERO NOVOA, I. El portero de balonmano y las habilidades perceptiva: propuesta de entrenamiento en niños. E-balonmano.com: Revista de Ciencias del Deporte, Granada, v. 3, n. 8, p.209-222, 2012.

SÁ, P. et al. Percepción de los porteros expertos en balonmano de los factores determinantes para el éxito deportivo. Revista de Psicología del Deporte, v.24, n.1, p.21-27, 2015.

SÁNCHEZ MECA, J. Cómo realizar una revisión sistemática y un meta-análisis. Aula Abierta, Oviedo, v.38, n.2, p.53-64, 2010.

SKARBALIUS, A.; PUKÉNAS, K.; VIDUNAITÉ, G. Sport performance profile in men's european modern handball: discriminant analysis between winners and losers. Education Physical Training Sport, Lituânia, v. 90, n. 3, p.44-54, 2013.

TELES, N.; VOLOSSOVITCH, A. Influência das variáveis contextuais no desempenho das equipes nos últimos 10 minutos do jogo de handebol. Revista Brasileira de Educação Física e Esporte, v. 29, n. 2, p.177-187, jun. 2015.

VALCÁRCEL, J. V. et al. La colaboración científica en el campo de las Ciencias de la Actividad Física y el Deporte en España. Revista Española de Documentación Científica, v.33, n.1, p.90-105, 2010. 
VOLPATO, G.L. Método lógico para redação científica. Botucatu: Best Writing, 2011.

WRIGHT, C.; CARLING, C.; COLLINS, D.. The wider context of performance analysis and it application in the football coaching process. International Journal Of Performance Analysis In Sport, Uk, p. 709-733, 2014. 


\section{CAPÍTULO 2 - MÉTODOS}

\section{TIPO DE PESQUISA}

De acordo com Silveira e Córdova (2009), a preocupação da pesquisa qualitativa não se baseia na representatividade numérica dos dados, mas na compreensão de um determinado grupo, organização ou fenômeno social. Flick (2009) aponta como aspectos fundamentais da pesquisa qualitativa, considerar a perspectiva dos sujeitos nela envolvidos e a reflexividade do pesquisador para com essas perspectivas.

A pesquisa qualitativa desenvolve-se por meio de uma fase de escolha do assunto ou problema a ser estudado e da coleta e análise das informações (TRIVIÑOS, 1987), e apresenta cinco características: a) a fonte de dados é seu ambiente natural e o pesquisador é o instrumento; b) os dados coletados são descritivos; c) preocupa-se mais com o processo do que com o produto; d) os significados dos entrevistados às coisas assumem uma atenção especial pelo pesquisador; e e) a análise dos dados segue um processo de indução (TRIVIÑOS, 1987).

Quando se fala em pesquisa qualitativa há várias técnicas para a recolha/produção de dados, dentre os quais destacam-se: os questionários, as entrevistas, a observação, os estudos de caso e os relatos de experiências (MARCONI; LAKATOS; 2003). Nesta pesquisa, escolheuse a entrevista como instrumento da pesquisa qualitativa, por permitirem uma expressão do pensamento dos sujeitos em relação aos temas desenvolvidos de forma mais profunda e por ser considerado um instrumento de excelência da investigação social (TRIVIÑOS; 1987; MARCONI; LAKATOS; 2003).

Foi escolhida nesta pesquisa a entrevista semiestruturada que se caracteriza pela utilização de perguntas abertas, em que as questões pré-definidas servem como uma diretriz ao objetivo da pesquisa (MARCONI, LAKATOS, 2003; FLICK, 2009; THOMAS, NELSON, SILVERMANN, 2012). O participante é livre para responder às questões de acordo com o seu entendimento, no entanto o entrevistador pode realizar perguntas complementares para compreender melhor o fenômeno em pauta (MARCONI, LAKATOS, 2003; FLICK, 2009; THOMAS, NELSON, SILVERMANN, 2012).

Outro aspecto que influenciou a escolha por esse tipo de entrevista se deu pelo fato de entender que as informações a serem buscadas junto aos treinadores de handebol seriam 
muito específicas (MANZINI, 2012), envolvendo aspectos relacionados às características e formação do goleiro de handebol.

\section{CARACTERIZAÇÃO DOS PARTICIPANTES}

Participaram desta pesquisa 19 treinadores da categoria sub-16, de equipes do sexo masculino e/ou feminino, que participaram de competições organizadas pela Liga de Handebol do Estado de São Paulo e/ou pela Liga Paulistana de Handebol no ano de 2016. A escolha pelas competições citadas justificou-se pelo caráter regionalizado dessas. Em relação à categoria sub16, esta foi selecionada por ser apontada como a categoria em que se inicia o processo de especialização do goleiro de handebol pensando em uma formação esportiva de longo prazo (BENDA; GRECO, 2002).

A média de idade dos entrevistados foi de 40,8 anos ( \pm 8,3; mín: 30; máx: 55). Os entrevistados possuíam tempo médio de atuação profissional com o handebol, em diferentes categorias e âmbitos (escolar, clubes e equipes competitivas), de 16,2 anos ( \pm 7.9 ; mín: 2; máx: 30). Destaca-se que um dos treinadores entrevistados desenvolvia o trabalho exclusivo com o treinamento dos goleiros em uma das equipes. Não foi verificado trabalho semelhante (exclusivo com goleiros) em outras equipes.

Todos os entrevistados são formados em Educação Física, sendo alguns com Licenciatura Plena e outros com Bacharelado e/ou Licenciatura. Entretanto, em relação à pósgraduação, oito treinadores possuíam uma especialização em handebol. Além disso, nove treinadores possuíam outras certificações lato sensu (Especialização em Jogos Pré-Desportivos; Especialização em Fisiologia do Exercício; Especialização em Atividade Motora Adaptada). Apenas um treinador possuía um diploma stricto sensu (Mestrado).

Dos entrevistados, 13 atuaram com o handebol no ambiente escolar, e, quando nos referimos à categoria sub-16, esta engloba jovens em idade escolar. Alguns treinadores entrevistados iniciaram a sua carreira no handebol dentro da escola, seja nas aulas de Educação Física ou por meio de projetos de iniciação esportiva.

Além disso, 12 treinadores disseram que, na época das entrevistas, exerciam outra função profissional para além da função de treinador de handebol da categoria sub-16. Em relação às outras experiências profissionais, pode-se dizer que, de maneira geral, possuir uma outra função profissional influenciou de duas formas a carreira como treinador: de forma 
negativa, no sentido de terem menor tempo para planejar e trabalhar com o processo de EAT de suas respectivas equipes; de forma positiva, com o aprendizado de outras funções como, por exemplo, participar de comissão técnica em outras categorias.

A partir disso, o fato de ser professor de Educação Física em ambiente escolar, também foi apontado como um fator positivo pelos participantes, pois o objetivo de ensinar um grupo de alunos sobre um determinado esporte, considerando as especificidades da turma e as possíveis estratégias de ensino utilizadas, foi algo que permeou tanto o contexto escolar quanto o contexto das equipes competitivas. Ainda assim, dentro do grupo de treinadores que disseram possuir outra função profissional, apenas um sujeito afirmou que não influenciou sua carreira como treinador de handebol.

\section{ELABORAÇÃO DO INSTRUMENTO DE ENTREVISTA}

$\mathrm{O}$ instrumento de entrevista semi estruturada utilizado nesta pesquisa teve como ponto de partida metodológico o modelo desenvolvido e aplicado por Menezes (2011). Isto quer dizer que a elaboração do instrumento de entrevista desta pesquisa ocorreu a partir da discussão entre pesquisador e orientador, resultando em um modelo composto por nove questões, sendo estas divididas em dois blocos, distribuídos da seguinte forma: Dados Pessoais (cinco questões); Características dos Goleiros na Categoria Sub-16 (quatro questões).

A entrevista iniciou-se pelo bloco dos Dados Pessoais, que buscavam informações como idade, formação acadêmica (graduação e pós-graduação), tempo de atuação e experiência como treinador. Esse primeiro bloco teve como finalidade caracterizar o perfil do entrevistado e servir de "aquecimento" para o bloco temático principal da entrevista, fazendo com que o mesmo se sentisse confortável durante a realização das demais perguntas do instrumento (TRIVIÑOS 1987; MENEZES, 2011). Após o bloco inicial, a entrevista seguiu para o bloco temático principal das Características dos goleiros na categoria sub-16, como aponta o Quadro 4 abaixo com as perguntas do instrumento de entrevista. 
Quadro 4. Instrumento de entrevista semi estruturada

\section{DADOS PESSOAIS}

1. Qual a sua idade?

2. Possui curso de Graduação? Em qual área? Em que ano? Onde?

3. Possui curso de Pós-Graduação? Em qual área? Em que ano? Onde?

4. Há quanto tempo você atua como treinador? Quanto tempo em cada categoria?

5. Atua ou atuou como treinador em equipes no ambiente escolar? Em quais categorias? Por quanto tempo?

\section{CARACTERÍSTICAS DOS GOLEIROS NA CATEGORIA SUB-16}

6. Quais as características que você considera para uma especialização do goleiro de handebol?

7. Na sua opinião, quais são as principais capacidades técnico-táticas a serem desenvolvidas pelo goleiro de handebol nesta categoria? Como você avalia essas capacidades em treinos e em jogos? Que patamares você espera que essas capacidades alcancem?

8. O que um goleiro de handebol deve observar durante o ataque do adversário? E durante o ataque da sua equipe?

9. O que um goleiro de handebol deve observar em um arremesso de longa distância $(9 \mathrm{~m})$ para elaborar a sua tomada de decisão? E em um arremesso de curta distância $(6 \mathrm{~m})$ ? E em uma cobrança de $7 \mathrm{~m}$ ?

\section{PROCEDIMENTOS PARA ENTREVISTA}

Antes de entrar em contato com os treinadores o projeto foi submetido e aprovado pelo Comitê de Ética e Pesquisa (CEP) da Escola de Educação Física e Esporte de Ribeirão Preto da Universidade de São Paulo (EEFERP-USP), de acordo com o parecer 953.242 (CAAE: 39796814.8.0000.5659). ${ }^{1}$ No momento da entrevista os treinadores receberam uma via do Termo de Consentimento Livre e Esclarecido (TCLE), explicando sobre a pesquisa, os métodos e as técnicas que seriam utilizadas. É importante salientar que, no momento da entrega do TCLE, os treinadores foram informados sobre o sigilo de seus dados pessoais e o uso dos discursos para fins estritamente acadêmicos.

\footnotetext{
${ }^{1}$ Este é parte de um projeto maior intitulado "O discurso de treinadores de handebol do Estado de São Paulo sobre o processo de ensino-aprendizagem-treinamento em diferentes categorias"
} 
Os procedimentos para a realização das entrevistas foram pautados na metodologia proposta por Triviños (1987) e adotada por Menezes (2011), sendo apresentados em ordem cronológica: 1) definiçãa dos critérios da amostra; 2) contato inicial via e-mail ou telefone para apresentar o pesquisador, o orientador e a Universidade, além de explicar o objetivo da pesquisa e a importância da participação do treinador; 3) confirmada a participação, verificou-se a disponibilidade de data/horário para a entrevista, buscando a realização da mesma em momentos que não concorressem com a atividade profissional do treinador; 4) realização da entrevista com gravação na íntegra e realização de anotações de pontos relevantes; 6) transcrição da entrevista, iniciada geralmente no mesmo dia da sua realização.

As entrevistas foram realizadas em locais sem ruídos externos que pudessem comprometer a resposta do participante, seja em relação à gravação ou à sua atenção. Nos casos em que não foi possível o contato pessoal, foi proposto pelo pesquisador a realização da entrevista por meio do software de chamadas online Skype, no qual a entrevista foi realizada por meio de uma chamada de vídeo ao vivo. Caso o sujeito não possuísse o referido software, foi sugerida a realização da entrevista pelo aplicativo de celular WhatsApp ${ }^{\circledR}$, por meio da função de gravação de áudios, na qual o pesquisador gravou o áudio da pergunta e o entrevistado gravou o áudio da resposta. As opções supracitadas foram consideradas devido às diferentes regiões de residência dos treinadores no Estado de São Paulo, além dos custos para os deslocamentos até os locais de entrevistas o que dificultou, em alguns casos, o encontro pessoal entre pesquisador e treinador.

A entrevista foi gravada na íntegra por meio de um Gravador de Voz no celular do pesquisador (em caso de contato pessoal) e por meio de um plug-in de gravação da chamada online (em caso de contato via Skype). No caso específico do WhatsApp ${ }^{\circledR}$, os áudios ficavam gravados na memória do celular. Após a gravação, foi feito o upload do arquivo de áudio das entrevistas para armazenamento em nuvem (Google Drive), para que todas as informações produzidas pudessem ser arquivadas como backup. De forma conjunta, durante a entrevista, o pesquisador efetuou anotações de informações relevantes sobre as experiências do treinador para com uma determinada questão. Este procedimento serviu para solucionar eventuais dúvidas do entrevistado em relação a qualquer uma das questões do instrumento de entrevista. Para que não houvesse nenhuma dúvida, ao final da entrevista, o pesquisador questionou se o treinador não gostaria de acrescentar mais alguma informação diante dos temas discutidos. 
Após a finalização da entrevista, o pesquisador procedeu à transcrição da mesma. Esta foi a etapa mais trabalhosa, uma vez que tal processo demanda grande atenção e precisão para uma transcrição exata do discurso dos sujeitos entrevistados. Ao final da etapa de transcrição e como forma de validação das entrevistas, as transcrições foram enviadas para os respectivos treinadores para ajustes e correções, caso necessários.

\section{ANÁLISE DAS ENTREVISTAS: O DISCURSO DO SUJEITO COLETIVO}

Para a análise das entrevistas optou-se pelo método do Discurso do Sujeito Coletivo (DSC), que consiste em tabular, analisar e interpretar, de forma qualitativa, os discursos coletados em depoimentos/entrevistas (LEFÈVRE; LEFÈVRE, 2012).

O DSC é fundamentado na Teoria das Representações Sociais e dessa forma busca identificar as ideias socialmente compartilhadas em um determinado grupo. Por essa razão, este método não adota critério de saturação para definir o tamanho da amostra dos participantes. Isto pois, se o objetivo é identificar e discutir as ideias compartilhadas socialmente, poderá haver uma repetição de ideias e conceitos entre os participantes. Todavia, este método propõe a identificação de todas as ideias existentes dentro de um determinado grupo social e não somente aquelas que são mais compartilhadas (LEFÈVRE; LEFÈVRE, 2012).

Nesse sentido, poder-se-ão ser construídos quantos discursos forem necessários de acordo com as ideias que surgirem nos discursos (LEFÈVRE; LEFÈVRE, 2012). Outro aspecto relevante para não utilizar o critério de saturação no DSC é a separação entre as fases de produção e análise dos dados, uma vez que para proceder à construção dos discursos é necessário que os depoimentos de todos os sujeitos já tenham sido transcritos e tabulados (LEFÈVRE; LEFÈVRE, 2012).

O objetivo do DSC proposto por Lefèvre e Lefèvre (2012) resume-se na ideia de considerar a discursividade, que é característica do pensamento coletivo, em todos os momentos da pesquisa, desde a elaboração dos instrumentos de entrevista até o momento de apresentação dos dados. Dessa forma, o DSC é entendido como um "discurso-síntese" na primeira pessoa do singular que representa o pensamento de uma determinada população sobre um determinado tema, baseado em algumas figuras metodológicas presentes nos discursos dos sujeitos entrevistados, como as expressões-chave e as ideias centrais (LEFÈVRE; LEFÈVRE, 2012). As figuras metodológicas desse método são assim apresentadas (LEFÈVRE; LEFÈVRE, 2012): 
- $\quad$ Expressões-chave $(\mathrm{ECH})$ são os trechos literais do discurso que revelam a essência da entrevista, ou do conteúdo discursivo das partes em que se divide a entrevista.

- Ideias Centrais (IC), são expressões que descrevem sucinta, precisa e fidedignamente, o significado dos discursos analisados e de cada grupo de $\mathrm{ECH}$, os quais posteriormente, vão originar o DSC.

Para se construir o DSC, entendendo os conceitos de ECH e de IC, temos as seguintes fases: 1) leitura dos depoimentos; 2) identificação das ECH e IC; 3) agrupamento das ECH que compartilham da mesma IC; 4) elaboração do DSC (LEFÈVRE; LEFÈVRE, 2012).

Entendendo que a opinião dos treinadores foi fundamental para esta pesquisa, pois são eles que conduzem o processo de formação do goleiro de handebol, considerou-se que a opção pelo DSC foi o que efetivamente permitiu analisar os discursos desse grupo tão específico, buscando as identificar as ações que o goleiro deve realizar em situação de jogo, as características que suportam essas ações do goleiro e as características importantes para especializar um atleta como goleiro de handebol, considerando o contexto da categoria sub-16. 
CAPÍTULO 3 - AÇÕES DO GOLEIRO DE HANDEBOL EM SITUAÇÃO DE JOGO

A partir do panorama apontado no Capítulo 1, que permite apontar uma lacuna de estudos com goleiros jovens, neste capítulo estão apresentados os discursos dos treinadores da categoria sub-16 referentes a duas perguntas centrais. A primeira questão se refere ao que os treinadores pensam sobre o que os goleiros devem observar e como devem agir durante o ataque da sua equipe e posteriormente durante o ataque da equipe adversária. Já a segunda questão se refere ao que os treinadores responderam sobre o que os goleiros devem saber fazer diante de arremessos executados em diferentes distâncias.

\section{O QUE O GOLEIRO DEVE OBSERVAR NO ATAQUE DO ADVERSÁRIO PARA DEFENDER}

A razão principal de ouvir os treinadores em relação ao que o goleiro deve observar no ataque do adversário baseia-se no objetivo de identificar os principais aspectos que podem influenciar a tomada de decisão desse para realizar a defesa durante o jogo. O Quadro 5 apresenta as IC e os DSC encontrados nas respostas dos treinadores entrevistados no decorrer deste capítulo, seguido da discussão sobre os resultados encontrados de acordo com cada IC identificada.

Quadro 5. IC e DSC referentes à questão: "O que o goleiro deve observar no ataque do adversário para fazer a defesa?"

\begin{tabular}{|c|c|}
\hline $\begin{array}{l}\text { IC-1 Posição do } \\
\text { Braço de } \\
\text { Arremesso } \\
\text { (S2; S4; S5; S10; } \\
\text { S11; S13; S19) }\end{array}$ & 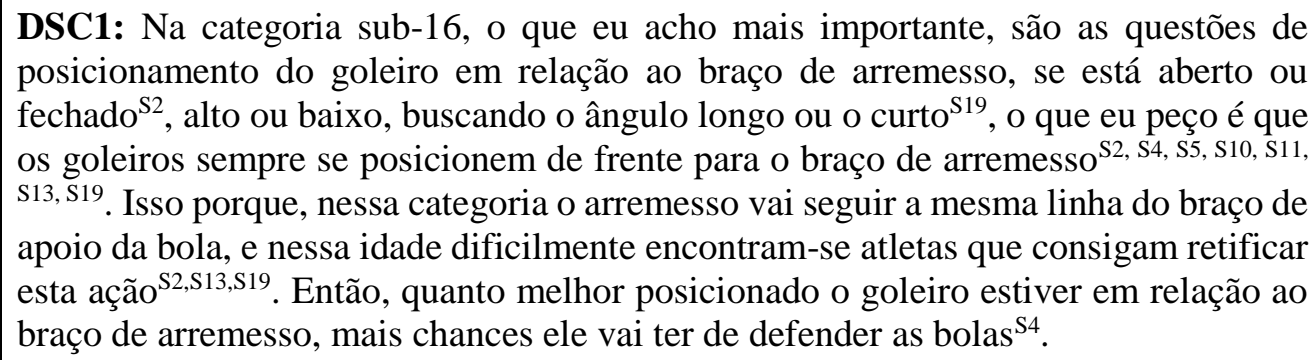 \\
\hline $\begin{array}{l}\text { IC-2 } \\
\text { Identificação do } \\
\text { Padrão de } \\
\text { Arremessos / } \\
\text { Principais }\end{array}$ & 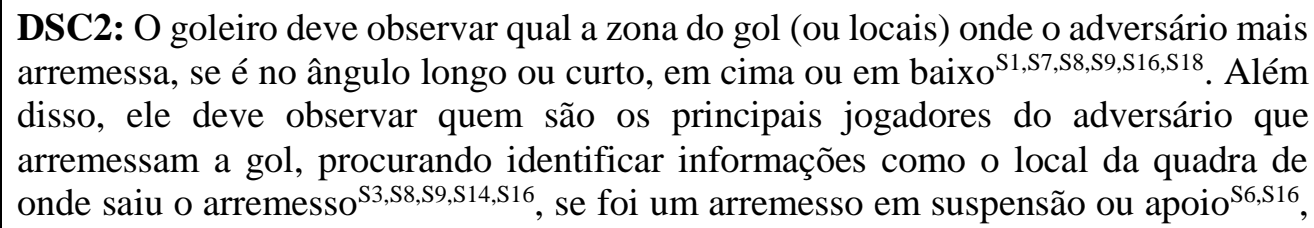 \\
\hline
\end{tabular}




\begin{tabular}{|c|c|}
\hline $\begin{array}{l}\text { Atacantes e suas } \\
\text { características } \\
\text { (S1; S3; S6; S7; } \\
\text { S8; S9; S14; } \\
\text { S16; S18) }\end{array}$ & $\begin{array}{l}\text { se o adversário é destro ou canhoto }{ }^{\mathrm{S} 6, \mathrm{~S} 9, \mathrm{~S} 16} \text {, se o arremesso é feito na primeira ou na } \\
\text { segunda passada }{ }^{\mathrm{S} 6} \text {, se é um jogador que infiltra mais ou se arremessa de longa } \\
\text { distância }^{\mathrm{S} 18} \text {. }\end{array}$ \\
\hline $\begin{array}{l}\text { IC-3 Trajetórias } \\
\text { do Atacante } \\
\text { (S4; S5; S7; S10; } \\
\text { S12; S14; S16; } \\
\text { S17) }\end{array}$ & $\begin{array}{l}\text { DSC3: Eu acho que ele deve observar o deslocamento do atacante e a sua trajetória } \\
\text { quando realiza determinado tipo de arremesso } \\
\text { observar a movimentação do ataque, para saber onde a bola está e para saber onde } \\
\text { está o jogador em posse da bola }{ }^{\mathrm{S} 14, \mathrm{~S} 17} \text {. É o que gente tem mais trabalhado, a questão } \\
\text { das diagonais, de longo e curto, porque normalmente se o atacante faz uma diagonal } \\
\text { longa, ele arremessa cruzado }{ }^{\mathrm{S4}, \mathrm{S5}} \text {, ou se ele faz uma quebra da trajetória inicial e muda } \\
\text { o posicionamento para o arremesso } \mathrm{a}^{\mathrm{S16}} \text {. Ao analisar vídeos de outros goleiros, percebe- } \\
\text { se que a trajetória do atacante é que o vai definir o arremesso; identificando este } \\
\text { aspecto, para o goleiro fica mais fácil }{ }^{\mathrm{S} 10} \text {. }\end{array}$ \\
\hline $\begin{array}{l}\text { IC-4 } \\
\text { Orientação da } \\
\text { Defesa/Bloqueio } \\
\text { Defensivo } \\
\text { (S3; S5; S6; S12; } \\
\text { S16; S17) }\end{array}$ & 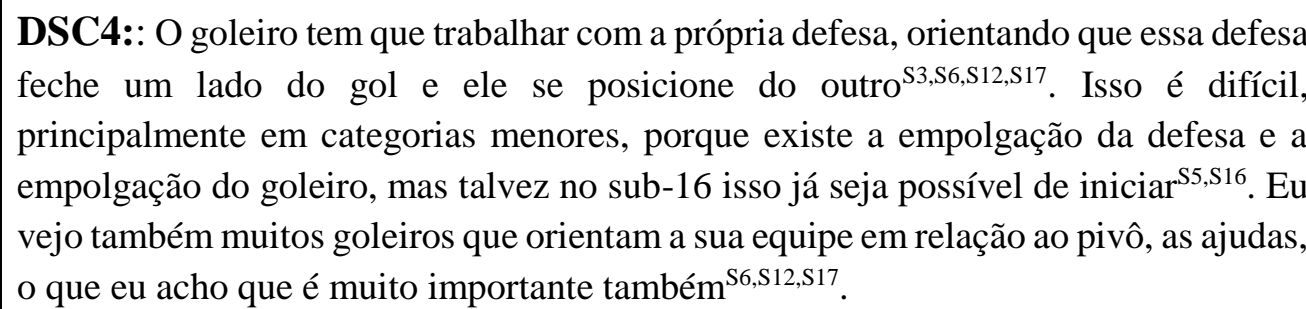 \\
\hline
\end{tabular}

\section{Posição do Braço de Arremesso}

Um dos aspectos que o goleiro de handebol na categoria sub-16 deve observar para defender, na opinião dos treinadores, está relacionado com a posição do braço de arremesso do adversário, identificando se o mesmo está com o braço mais aberto buscando o ângulo longo para o arremesso ou com o braço mais fechado buscando o ângulo curto. Esses aspectos vão influenciar no posicionamento do goleiro e consequentemente no feedback que é dado pelos treinadores aos atletas deste posto específico. No DSC1, ao explorar diferentes aspectos referentes à posição do braço, os treinadores indicam que é importante para o goleiro se posicionar de frente para o braço de arremesso do atacante, com a prerrogativa de aumentar suas chances de defesa.

A identificação do braço de arremesso, enquanto indicador do tipo ou localização da zona alvo do arremesso é considerado uma ação tática, influenciada por diversas situações do jogo, mas que fazem parte de um conjunto de outras características que auxiliam na realização da defesa do goleiro (GRECO; NEVES; MATIAS; 2002). 
Este é um indicador demasiado específico, que demanda um certo grau de experiência para se ter sucesso na sua identificação e que vai ao encontro dos fatores que influenciam a tomada de decisão de goleiros de handebol experientes e não-experientes (SÁ, FERNÁNDEZ ROMERO, GOMES, 2007). Os autores apontam que o braço de arremesso para goleiros experientes (aproximadamente 21 anos de prática e com experiência na $1^{\text {a }}$ divisão portuguesa) é um dos últimos indicadores observados para tomar a sua decisão em relação à defesa, momentos antes da bola sair da mão do jogador adversário.

Já para os goleiros não-experientes (aproximadamente 7 anos de prática e com experiências somente em divisões inferiores), o braço de arremesso apareceu como um dos únicos fatores percebidos por esses como indicador do arremesso, demorando mais tempo para tomar a sua decisão em relação à defesa (SÁ; FERNÁNDEZ ROMERO; GOMES; 2007). Essa diferença ocorre pelo fato de que os goleiros não-experientes não estão sensíveis a certos estímulos pelo menor tempo de prática e também pelo menor nível competitivo em que atuam.

Diante das ideias apresentadas entende-se que o braço de arremesso é um indicador importante para a realização da defesa do goleiro em qualquer categoria. Essa perspectiva corrobora Antúnez Medina (2003), que aponta que para identificar a direção do arremesso, o goleiro deve centrar a sua atenção no movimento do braço e na empunhadura do jogador em posse da bola. No entanto, se considerarmos a experiência dos atletas na categoria sub-16 (que estão em formação e com pouca experiência), desenvolver a atenção e a identificação do braço de arremesso adversário faz-se importante e parece ser o elemento mais simples a ser ensinado ao goleiro.

Outro aspecto destacado pelos treinadores sobre a importância de se desenvolver a identificação do braço de arremesso pelo goleiro, referiu-se principalmente à pouca variação do arremesso na categoria sub-16 após o planejamento da ação. Isto é, se o goleiro conseguir identificar este aspecto de maneira antecipada, maior poderá ser a chance de defesa. Segundo Sá, Fernández Romero e Gomes (2007) isto ocorre pois este é um indicador de que se o goleiro antecipar-se demasiadamente ao arremesso o atacante ainda terá a chance de retificar o arremesso (mudar a angulação do braço) mas, ao mesmo tempo, se acertar o tempo de reação, dificilmente o atacante consegue mudar a zona alvo do arremesso. Esse timing de antecipação do arremesso, melhora de acordo com o desenvolvimento da identificação dos sinais relevantes (como o braço de arremesso) pelo goleiro (HELM; REISER; MUNZERT, 2016). 


\section{Identificação do Padrão de Arremessos e Características dos Atacantes}

Como apontado anteriormente, na categoria sub-16 há uma dificuldade dos atacantes em conseguir retificar o arremesso, o que traz a importância da capacidade de identificar o braço de arremesso dos atacantes. Seguindo esta mesma linha, devido à dificuldade de retificação dos arremessos, os treinadores relatam no DSC2 que há a criação de certos padrões de arremesso, nos quais um determinado jogador pode preferir quase sempre arremessar da mesma forma ou no mesmo local do gol, o que facilitaria a antecipação ao resultado do arremesso.

A identificação de um padrão de arremessos passa, na opinião expressa no DSC2, pela capacidade do goleiro de identificar algumas características dos atletas envolvidos na situação de jogo, como o tipo de arremesso preferido, o local da quadra de onde arremessam e o local do gol em que o arremesso foi mais executado.

Assim sendo, identificar o padrão de arremesso de um determinado jogador e/ou equipe faz-se importante para o goleiro, uma vez que facilita o seu trabalho de possíveis antecipações em detrimento das possibilidades apresentadas pelos atacantes. Diantes dessas possibilidades de arremesso, Zeir (1987) aponta que os lançamentos mais difíceis de serem defendidos são aqueles direcionados para as zonas inferiores do gol (pois dependem da flexibilidade do goleiro) e aqueles direcionados a uma zona de meia-altura próxima da trave.

Uma das características que influencia no tipo de arremesso é o posto específico ofensivo, pois a partir dessa referência tem-se uma bissetriz formada em relação ao atacante com a bola e os ângulos longo e curto do gol (GRECO; NEVES; MATIAS; 2002; ANTÚNEZ MEDINA; 2003), que são diferentes de acordo com o posto específico que executa o arremesso. No estudo de Prudente, Garganta e Anguera (2004) o indicador "Localização do Atacante" foi o segundo indicador mais apontado pelos treinadores como sendo determinante para a análise do rendimento do goleiro, ficando atrás apenas da “Ação do Goleiro para defender o gol”.

Pascual Fuertes e Peña Barceló (2006) apresentam uma proposta de treinamento perceptivo para o goleiro de handebol diante de arremessos da primeira linha ofensiva (realizados pelos armadores esquerdo, direito e central). Os autores dividem em quatro fases o momento do arremesso e apresentam indicativos que o goleiro deve observar para se posicionar e tentar realizar o movimento de defesa. Na fase inicial o goleiro deve ter atenção à posição do 
atacante em quadra que tem a bola e ao braço dominante desse. Na fase dois, chamada de fase de ataque, o goleiro recai a sua atenção ao ciclo de passadas do atacante no momento do arremesso, procurando perceber se o mesmo finaliza em um, dois ou três passos. Na fase três, denominada fase de execução, deve-se considerar como é realizado o salto para o arremesso, se este é executado em apoio ou em suspensão e, ainda, se é realizado ou não com os pés trocados. Nesta fase, também é preciso observar o braço de arremesso e o trabalho em conjunto com a defesa. Na fase quatro, o goleiro tem que ser capaz de analisar o resultado da ação, mediante a zona do gol a qual foi direcionado o arremesso e a efetividade do arremessador para cada um dos espaços possíveis de finalização, procurando identificar em qual zona o atacante arremessou com maior frequência e em qual teve melhor aproveitamento.

Vários desses aspectos apontados pelos autores supracitados também são mencionados pelos treinadores no DSC2, como a localização do jogador, o tipo de salto para o arremesso (apoio ou suspensão), o braço dominante e se ele arremessa com um, dois ou três passos. Percebe-se, dessa forma, uma aproximação entre o pensamento dos entrevistados com os aspectos apontados pelos diferentes autores.

Obviamente que o nível de competição e a experiência na posição, como já salientado anteriormente (SÁ; FERNÁNDEZ ROMERO; GOMES; 2007; SÁ et al., 2015), vão influenciar a capacidade do goleiro de identificar o padrão de arremesso. Todavia, trabalhar com os goleiros sub-16 a identificação de determinados sinais relevantes (GRECO; 1988), é uma prática interessante que auxilia no entendimento do jogo e, consequentemente, na melhora do desempenho desses.

No entanto, assim como apontado no Capítulo 1, a maioria dos estudos abordados nesta seção envolveu equipes adultas. Dessa forma, as características apontadas pelos treinadores podem ser ensinadas aos goleiros da categoria sub-16, desde que apontem para uma perspectiva de desenvolvimento a longo prazo. Isto significa que não se deve exigir dos atletas nas categorias jovens que consigam identificar frequentemente o padrão de arremessos e as características dos atacantes da forma exigida para os goleiros adultos. É preciso que esta capacidade seja estimulada de acordo com as características individuais do goleiro, considerando o seu entendimento do jogo e do posto específico, além de respeitar sua categoria no processo de EAT (GRECO, 2002). 
Trajetórias dos Atacantes

O terceiro fator apontado como importante para a observação do goleiro durante o ataque da equipe adversária são as trajetórias dos atacantes no momento do arremesso, representado pelo DSC3. Nesse discurso os treinadores abordaram a identificação das trajetórias de arremesso dos atacantes como um dos aspectos fundamentais para definir a ação de defesa do goleiro.

Assim como apontado no DSC3, a trajetória que o atacante com a bola faz no momento do arremesso é um fator no qual o goleiro precisa prestar atenção, pois pode ajudá-lo a se posicionar de forma mais rápida para executar uma defesa (BENDA; XAVIER; MARTINI, 2002).

O bom arremesso deve ser capaz de conciliar a precisão com a escolha da melhor trajetória para a posição em que se está em quadra (ANTÚNEZ MEDINA, 2003). Nesse sentido, o atacante buscará sempre atacar a zona com a maior perpendicularidade e profundidade em relação ao gol, ou seja, a zona central da quadra de ataque/defesa é a que oferece os melhores ângulos e campo visual ao atacante para executar o arremesso (ANTÚNEZ MEDINA, 2003). No entanto, isso está relacionado também com a trajetória do atacante, se ela é efetuada em relação ao ponto forte (a favor do braço de arremesso), ao ponto débil (contra o braço de arremesso) ou se é reta (PASCUAL FUERTES; PEÑA BARCELÓ, 2006). A importância de se entender os conceitos dos tipos de trajetórias é que a maioria dos arremessos de primeira linha ocorrem com trajetórias direcionadas ao ponto forte do atacante, segundo uma análise com 612 arremessos de equipes da primeira divisão adulta masculina da liga espanhola de handebol na temporada 2003-2004 (PASCUAL FUERTES; PEÑA BARCELÓ, 2006).

Por ser um fator que depende principalmente da movimentação inicial do atacante para o arremesso e que irá procurar o melhor local para que consiga se aproximar do gol em boas condições de finalização, a trajetória é um dos primeiros sinais que o atacante oferece ao goleiro no momento de sua ação em direção ao gol. Arias Estero (2009) aponta que o goleiro deve considerar as trajetórias do atacante com a bola, para conseguir vantagem no tempo de reação para a defesa. No entanto, perceber esta trajetória e conseguir associar essa informação para antecipar o movimento do atacante e fazer a defesa é algo um pouco mais complexo e que é diretamente influenciado pelo nível competitivo e pela experiência na posição (SÁ et al., 2015). Enquanto os goleiros experientes identificam primeiro e de forma bastante antecipada a 
trajetória do atacante, os goleiros não-experientes têm dificuldades em identificar a trajetória como indicador da ação do atacante (SÁ; FERNÁNDEZ ROMERO; GOMES, 2007).

Analisando esses aspectos, entende-se que a leitura de trajetórias do atacante deve ser enfatizada com os goleiros principalmente em categorias menores, como a sub-16. Trata-se de um indicador de caráter global (SÁ; FERNÁNDEZ ROMERO; GOMES, 2007) que pode ser percebido mais cedo, favorecendo a antecipação da defesa pelo goleiro. No DSC3 é mencionado que a identificação das trajetórias dos atacantes pode favorecer a descoberta de um ângulo mais aberto e longo ou de um ângulo mais fechado e curto. Assim, se houver uma mudança de trajetória do atacante, o goleiro deverá reorganizar o seu posicionamento em função dessa mudança.

O trecho final do DSC3 afirma que a trajetória do atacante poderá predizer a trajetória da bola após o arremesso. Porém, há que se atentar para não estereotipar comportamentos, por exemplo, se o atacante tomar a trajetória para o centro da defesa e for um destro jogando na função de armador esquerdo, não se pode pensar que o arremesso vai ser sempre no ângulo longo baixo, apesar de evidência estatística sobre essa situação (PASCUAL FUERTES; PEÑA BARCELÓ, 2006). Existe a possibilidade do atacante mudar o arremesso ou mesmo a ação para um passe ao pivô ou outro jogador próximo a ele, caracterizando a imprevisibilidade da situação de jogo (SCAGLIA et al., 2013).

Pode-se considerar portanto, que a leitura das trajetórias dos atacantes é complexa em exercício, mas deve ser encorajada pelos treinadores. Assim, esta deve ser treinada de maneira aberta e sem estereótipos com os goleiros, estimulando o desenvolvimento de suas capacidades cognitivas, especialmente de percepção e antecipação, que irão embasar a sua tomada de decisão diante das trajetórias realizadas (MATIAS; GRECO, 2010).

\section{Trabalho Colaborativo com a Defesa}

Em relação ao ataque adversário, o último aspecto citado que o goleiro deve observar para fazer a sua defesa é justamente o trabalho colaborativo com os defensores. Esse trabalho colaborativo implica na criação de situações que sejam vantajosas e que auxiliem no sucesso do sistema defensivo como um todo. O DSC4 aborda alguns pontos referentes a essa característica, essencialmente sobre de que forma desenvolver a relação goleiro-defensor, as dificuldades de ensinar e outras particularidades sobre esta relação. 
No DSC4 é apontado que esta relação pauta-se em um trabalho conjunto no qual é esperado que os defensores protejam um lado do gol e o goleiro se posicione do outro. Menezes (2011) diz que o objetivo desse trabalho entre defensor e goleiro é induzir o atacante o arremessar das zonas laterais da quadra e/ou tentar desequilibra-lo no momento da finalização. Além disso, deverá haver um sincronismo entre o posicionamento do goleiro e a atuação dos bloqueios defensivos de forma limitar os espaços possíveis de arremesso (MENEZES, 2011), assim como apontado no DSC4. Todavia, o goleiro não pode se limitar apenas a proteger uma parte específica do gol, pois em caso de retificação do arremesso pelo adversário, ou mesmo de um desvio, é ele o único jogador que ainda pode defender a bola (GRECO; NEVES; MATIAS, 2002).

Desenvolver a relação goleiro-defensor é um importante aspecto para que o goleiro consiga antecipar a sua reação, de forma a ter vantagem sobre o arremesso do atacante adversário. Sá, Fernández Romero e Gomes (2007) apontam que o trabalho colaborativo entre goleiro e defesa é um dos aspectos que os goleiros mais experientes utilizam para antecipar a trajetória da bola e realizar a sua defesa diante de arremesso da primeira linha ofensiva. Para os goleiros não-experientes esse é um dos únicos fatores que conseguem utilizar para antecipar a sua ação defensiva, juntamente com o posicionamento do braço de arremesso (SÁ; FERNÁNDEZ ROMERO; GOMES, 2007).

A partir disso, justifica-se o trabalho de desenvolvimento dessa característica ao longo do processo de EAT do goleiro de handebol, por influenciar o desempenho desse independentemente da idade. Entretanto, não significa que o nível de desempenho será semelhante entre os goleiros mais experientes e os menos experientes, mas que se constitui como uma característica importante para o goleiro. O DSC4 aponta que a empolgação do goleiro e dos defensores em querer evitar o gol adversário pode dificultar o treinamento dessa característica em categorias jovens, devido a possíveis equívocos na distribuição espacial dos defensores ou pelo posicionamento do goleiro, que pode definir sua ação muito antecipadamente e permitir a retificação do arremesso pelo adversário. Contudo, os treinadores acreditam já ser possível (e necessário) iniciar esse tipo de trabalho na categoria sub-16, por ser a fase em que se inicia o processo de especialização do goleiro.

Se pensarmos mais uma vez no processo de EAT e na etapa em que é apontado o início de um trabalho com as capacidades cognitivas (GRECO; BENDA, 2002), estimular que 
o goleiro seja capaz de combinar o seu posicionamento com o posicionamento dos seus defensores é um fator complexo do ponto de vista do entendimento do jogo, principalmente por aumentar os elementos e as possibilidades de ação dentro do mesmo, atingindo o último nível das relações entre os jogadores no ensino de um jogo esportivo coletivo (JEC) que é o "eu-bolaequipe-adversários" (GARGANTA, 1998). Essa atribuição de responsabilidades ou tarefas específicas favorece o bom desempenho do goleiro no jogo, a partir do estabelecimento de diretrizes específicas para defensores e goleiros.

Outra característica apontada no DSC4 sobre a relação goleiro-defensor é a de orientação e comunicação do goleiro para com os defensores no sentido de alertá-los sobre eventuais circulações, desdobramentos ou outras situações específicas do jogo. Materializa-se a ideia de "divisão de responsabilidades" entre goleiro e defensor, com o objetivo de evitar o gol adversário (GRECO; NEVES; MATIAS; 2002). Se por um lado, o nível desse trabalho conjunto vai depender da experiência do goleiro para conseguir perceber os bloqueios defensivos e os posicionamentos a se executar nesses momentos, talvez introduzir a noção de “colaboração defensiva" por meio de referências do próprio jogo (como o lado do posicionamento do pivô ou a circulação de um dos pontas etc.) seja uma boa estratégia para o treinador adotar ao longo do processo de EAT do goleiro de handebol, especialmente na categoria sub-16.

\section{O QUE O GOLEIRO DEVE OBSERVAR NO ATAQUE DA SUA EQUIPE}

Quando se pensa na atuação do goleiro de handebol, o primeiro ponto a se destacar está relacionado com as suas ações defensivas, independentemente do nível e/ou categoria, conforme abordado na seção anterior. Entretanto, autores como Greco (2002) e Thiengo, Vitório e Ferreira (2006) vão salientar que o goleiro também é o "primeiro atacante" da sua equipe, pois iniciam o processo ofensivo por meio de uma defesa seguida da reposição da bola em jogo.

No Quadro 6 estão apresentados os DSC elaborados a partir do questionamento sobre o que o goleiro deve observar no ataque da sua própria equipe. 
Quadro 6. IC e DSC referentes à questão: "O que o goleiro deve observar no ataque da sua equipe?"

\begin{tabular}{|c|c|}
\hline $\begin{array}{l}\text { IC-5 } \\
\text { Reposição de } \\
\text { Bola Rápida e } \\
\text { Iniciação do } \\
\text { Contra-Ataque } \\
\text { (S1; S3; S4; S7; } \\
\text { S8; S9; S10; } \\
\text { S13; S14; S16; } \\
\text { S17) }\end{array}$ & $\begin{array}{l}\text { DSC5: No ataque da minha equipe, cada vez mais a gente tem colocado a situação } \\
\text { de reposição de bola rápida para a transição ser mais eficiente, de forma a chegar a } \\
\text { campo de ataque em superioridade numérica e não deixando que a defesa consiga } \\
\text { realizar o seu retorno defensivo completamente } \mathrm{S1}, \mathrm{S3}, \mathrm{S4}, \mathrm{S7}, \mathrm{S} 8, \mathrm{S9}, \mathrm{S10}, \mathrm{S13}, \mathrm{S14}, \mathrm{S16}, \mathrm{S17} \text {. O } \\
\text { goleiro é o primeiro atacante, então eu trabalho muito essa situação de quando tem } \\
\text { um tiro lateral ele que vai cobrar ou uma falta nossa, ele que vai cobrar para dar mais } \\
\text { velocidade ao ataque } \mathrm{S1}, \mathrm{S} 3, \mathrm{~S} 7, \mathrm{~S} 8, \mathrm{~S} 9, \mathrm{S14} \text {. Para isso, ele precisa ter um passe apurado para } \\
\text { efetuar os lançamentos direto de contra-ataque e caso não seja possível, perceber em } \\
\text { seu campo visual qual é o atacante melhor posicionado para receber a bola e iniciar } \\
\text { um contra-ataque sustentado } \mathrm{S1}, \mathrm{S} 8, \mathrm{~S} 9, \mathrm{S13}, \mathrm{S16}, \mathrm{S17} \text {. }\end{array}$ \\
\hline $\begin{array}{l}\text { IC-6 } \\
\text { Orientação } \\
\text { durante o ataque } \\
\text { (S2; S12; S18; } \\
\text { S19) }\end{array}$ & $\begin{array}{l}\text { DSC6: Quando o meu time está atacando, os goleiros olham muito os goleiros } \\
\text { adversários e orientam os nossos atacantes, quanto ao arremesso. Por eles treinarem } \\
\text { os fundamentos, treinarem as movimentações, eles orientam os nossos atacantes }{ }^{\mathrm{S}, \mathrm{S}} \mathrm{S} \text {, } \\
\text { s18. Tudo vai depender do conhecimento tático que o meu goleiro vai ter, assim ele } \\
\text { pode conseguir orientar o meu ataque sobre os problemas da defesa adversária, } \\
\text { indicando espaços vazios por exemplo }{ }^{\mathrm{S} 12, \mathrm{~S} 18, \mathrm{~S} 19} \text {. Eu incentivo esse comportamento } \\
\text { deles falarem com o pessoal que está atacando }{ }^{\mathrm{S12}} \text {. }\end{array}$ \\
\hline $\begin{array}{l}\text { IC-7 } \\
\text { Não acredita que } \\
\text { participa do } \\
\text { ataque } \\
\text { (S5) }\end{array}$ & DSC7: No infantil e no cadete, não acredito não ${ }^{\mathrm{S5}}$. \\
\hline
\end{tabular}

\section{Reposição rápida da bola e Iniciação do Contra-Ataque}

Ao considerar o goleiro de handebol como o primeiro atacante de sua equipe, repor a bola em jogo rapidamente após uma ação de defesa é um dos aspectos mais citados por diferentes autores como importantes no desempenho do goleiro (GRECO; FERREIRA FILHO; OLIVEIRA JUNIOR; 2002; PRUDENTE; GARGANTA; ANGUERA; 2004; THIENGO; VITÓRIO; FERREIRA; 2006; ARIAS ESTERO; 2009; MENEZES; 2011).

O DSC5 apresentou inicialmente a importância e os objetivos de enfatizar a reposição de bola rápida pelo goleiro, citando alguns momentos em que este aspecto é mais exigido, como nas cobranças de falta ou de laterais para acelerar a transição de sua equipe para o ataque. No trecho final do DSC5 os treinadores apontam que ter um bom passe é uma característica necessária para que o goleiro consiga repor a bola em jogo rapidamente e com 
precisão, seja para iniciar um contra-ataque simples ou sustentado, por meio de uma passe para um jogador melhor posicionado quando não é possível o lançamento direto.

Prudente, Garganta e Anguera (2004) validaram as ações do goleiro para a categoria "Recuperação da Posse de Bola" em seu modelo de análise de jogo no handebol. Considerando o fato de que o goleiro de handebol só pode recuperar a posse de bola defendendo o arremesso, este deve manter o controle da bola para conseguir repor a bola em jogo para os seus companheiros. Além disso, quando há a marcação de uma falta a favor da sua equipe ou tiro lateral próximo de sua área, é o goleiro quem deve repor a bola em jogo, possibilitando que seus companheiros se posicionem para uma ação veloz de contra-ataque em vantagem contra o adversário (PRUDENTE; GARGANTA; ANGUERA, 2004).

Percebe-se pelo discurso dos treinadores (DSC5) que a atuação do goleiro durante o ataque da própria equipe está relacionada à velocidade das fases de transição do handebol, em especial das ações de contra-ataque. O contra-ataque pode ser caracterizado em três "ondas" de acordo com Menezes (2011), sendo a primeira onda, o momento em que sai a primeira linha de defensores para contra-atacar podendo recepcionar a bola por meio de um passe direto do goleiro; a segunda onda e a terceira onda, são outras linhas de jogadores que saem para sustentar a primeira linha que saiu anteriormente. Diante disso, o goleiro continua tendo a opção de executar o passe direto com a primeira linha, mas caso haja alguma dificuldade nesse sentido (retorno defensivo dos pontas, falta de confiança no lançamento), o goleiro também pode passar a bola para as linhas posteriores de forma a dar seguimento ao contra-ataque sustentado, por meio de leitura da situação técnico-tática do adversário no momento (balanço defensivo mal feito ou situações de assimetria numérica, etc.) (MENEZES, 2011).

Foi apontado no DSC5 que o goleiro deve ser capaz de realizar o passe direto sempre que possível, mas deve analisar a situação e identificar em seu campo visual os jogadores que estão melhor posicionados para fazer o passe e iniciar o contra-ataque de forma sustentada. Para esta situação, Arias Estero (2009) diferencia o que seria ação técnica do lançamento e do passe, em uma situação de reposição de bola para iniciar o contra-ataque. Para o autor, o lançamento é a ação que ocorre após a defesa de um arremesso, e que ao ter o controle da bola o goleiro observa se ao menos um dos pontas adversários estão mal posicionados para lançar a bola ao seu companheiro que estará em vantagem para finalizar. Uma vez não sendo possível o lançamento direto, a opção pelo passe deve ocorrer rapidamente para um de seus 
companheiros mais próximos do gol, de forma tornar possível a continuidade do contra-ataque em velocidade (ARIAS ESTERO, 2009)

\section{Orientação durante o processo ofensivo}

Para além da reposição de bola rápida e iniciação do contra-ataque direto ou sustentado de sua própria equipe, o goleiro tem também um papel de orientação da própria equipe durante a fase ofensiva, assim como mencionado no DSC6.

Para Thiengo, Vitório e Ferreira (2006) deve-se atribuir ao goleiro outras características relevantes, como a responsabilidade de orientar taticamente a sua equipe na fase defensiva ou ofensiva. Isso ocorre devido ao seu posicionamento privilegiado em quadra, que o permite observar determinados aspectos que podem ser relevantes para o jogo da sua equipe (THIENGO; VITÓRIO; FERREIRA; 2006).

Os treinadores apontaram que incentivam seus goleiros a conversarem o tempo todo com os jogadores da linha, principalmente durante o processo ofensivo da sua equipe. O DSC6 aponta a necessidade de o goleiro ser capaz de orientar a sua equipe, observando aspectos como a postura do goleiro adversário para indicar ao atacante de que forma executar o arremesso ou mesmo pelo fato de conhecer o modelo de jogo de sua equipe, que permite auxiliar seus companheiros de equipe com feedbacks técnico-táticos da situação de jogo, para conseguir vantagem sobre o adversário.

Tornar o goleiro responsável por ajudar na orientação da sua equipe dentro de quadra é um facilitador do desenvolvimento do atleta ao longo do processo de EAT. Segundo Loffredo e Greco (2002) o desenvolvimento da inteligência tática do goleiro de handebol é algo que merece atenção especial, principalmente quando trata-se de categorias de formação. Para que o goleiro consiga entender o modelo de jogo de sua equipe e identificar as características do adversário, esse precisa ser estimulado a pensar o jogo, percebendo alguns sinais relevantes (GRECO, 1988) que podem trazer indicativos de vantagens para a sua equipe. Contudo, ao se pensar no desenvolvimento de goleiros nas categorias de formação, é relevante considerar o desenvolvimento da orientação tática da própria equipe em situação de jogo, pautando-se em diretrizes estabelecidas pelo treinador para o jogo coletivo ofensivo e defensivo.

Na categoria sub-16, durante o desenvolvimento da percepção dos sinais relevantes da situação de jogo, o goleiro deve ser estimulado a perceber o que vai acontecer para tentar 
antecipar a sua ação defensiva (GRECO; BENDA; 2002). Porém, é desejável que se o atleta passou por categorias anteriores (como a sub-12 e a sub-14) ${ }^{2}$ que ele tenha vivenciado os demais postos específicos para entender suas características e implicações para atacantes e goleiro. Essa experiência irá permitir que o goleiro reconheça mais facilmente, quando na categoria sub-16 ou posteriores, as movimentações ofensivas, defensivas e do goleiro adversário. Dessa forma, terá subsídios para argumentar com a sua equipe, fornecendo importantes feedbacks técnicotáticos durante o jogo.

Para finalizar este bloco, o DSC7 mostrou uma opinião contrária às demais, de que não acredita ser possível que o goleiro tenha que observar alguma coisa durante o ataque da sua equipe. Este discurso vai contra os achados da literatura anteriormente citada, que apontam a importância do goleiro no processo ofensivo da sua equipe.

\section{O QUE O GOLEIRO DEVE FAZER PARA DEFENDER UM ARREMESSO EM DIFERENTES DISTÂNCIAS}

Nesta seção serão apresentados e discutidos os discursos elaborados a partir das ações que devem ser realizadas pelos goleiros para tentar defender a bola diante de arremessos de longa distância (9m), curta distância $(6 \mathrm{~m})$ e em cobranças de tiro de $7 \mathrm{~m}$.

As subseções serão baseadas nas IC de cada discurso, nos quais serão indicadas as distâncias de arremessos que estão contempladas em cada IC com o seu respectivo DSC no Quadro 7.

Quadro 7. IC e DSC referente à questão: "O que o goleiro deve fazer para defender um arremesso em diferentes distâncias?"

\begin{tabular}{|c|c|}
\hline $\begin{array}{l}\text { IC-8 (9m) } \\
\text { Leitura do } \\
\text { Arremesso } \\
\text { (S1; S6; S8; S14; } \\
\text { S15; S17) }\end{array}$ & $\begin{array}{l}\text { DSC8: No arremesso de } 9 \mathrm{~m} \text {, o goleiro tem que trabalhar principalmente com a } \\
\text { observação, a leitura de arremesso }{ }^{\mathrm{S1} ; \mathrm{S6} ; \mathrm{S} 8 ; \mathrm{S} 14 ; \mathrm{S} 15 ; \mathrm{S} 17} \text { para identificar o momento em que } \\
\text { vai ocorrer o arremesso, se colocando em uma posição mais favorável para a } \\
\text { defesa }^{\mathrm{S} 14} \text {. O que eu peço mais é que os goleiros façam um scouting dos atacantes }{ }^{\mathrm{S6} ; \mathrm{s} 8} \\
\text { para definir, por exemplo, quem arremessa mais fraco ou mais forte e qual a zona do } \\
\text { gol que sofre mais arremessos }{ }^{\mathrm{S6} ; \mathrm{S} 17} \text {, assim eles vão conseguir antecipar um pouco o } \\
\text { arremesso para conseguir fazer a defesa }{ }^{6} \text {. Mas ele deve tomar cuidado para não }\end{array}$ \\
\hline
\end{tabular}

\footnotetext{
${ }^{2}$ No Brasil, uma das maiores dificuldades dos treinadores é que muitos jogadores acabam iniciando a prática do handebol tardiamente, o que resulta na formação de grupos heterogêneos, nos quais há atletas que já tem alguma vivência no handebol e atletas que nunca praticaram algum esporte (MENEZES, 2010)
} 


\begin{tabular}{|c|c|}
\hline & $\begin{array}{l}\text { antecipar muito, não tentar adivinhar }{ }^{\mathrm{S} 8} \text { pois o atacante pode retificar o arremesso e } \\
\text { tirar o goleiro da situação de defesa }{ }^{515} \text {. }\end{array}$ \\
\hline $\begin{array}{l}\text { IC-9 }(9 m) \\
\text { Sinais } \\
\text { Relevantes para } \\
\text { a definição do } \\
\text { posicionamento } \\
\text { tático } \\
(\text { S1; S2; S3; S4; } \\
\text { S6; S7; S9; S10; } \\
\text { S11; S12; S13; } \\
\text { S16; S17; S18; } \\
\text { S19) }\end{array}$ & 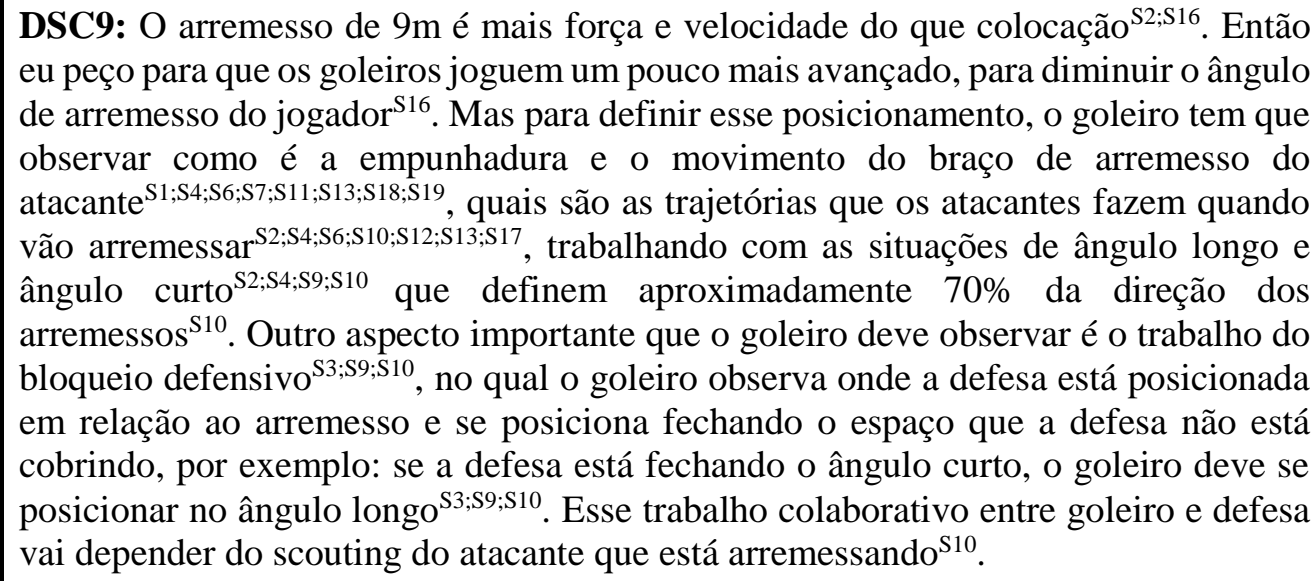 \\
\hline $\begin{array}{l}\text { IC-10 (9m) } \\
\text { Reações Rápidas } \\
\text { do Goleiro de } \\
\text { Handebol } \\
\text { (S2; S6; S7; S13; } \\
\text { S15; S19) }\end{array}$ & 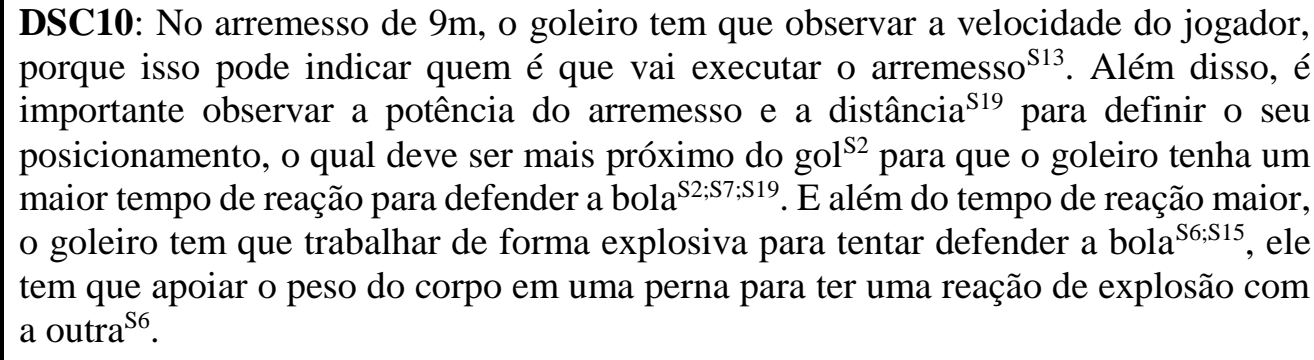 \\
\hline $\begin{array}{l}\text { IC- } 11(6 \mathbf{m}) \\
\text { Ações para } \\
\text { diminuir o } \\
\text { espaço de } \\
\text { arremesso do } \\
\text { atacante } \\
\text { (S1; S2; S4; S6; } \\
\text { S9; S10; S14) }\end{array}$ & 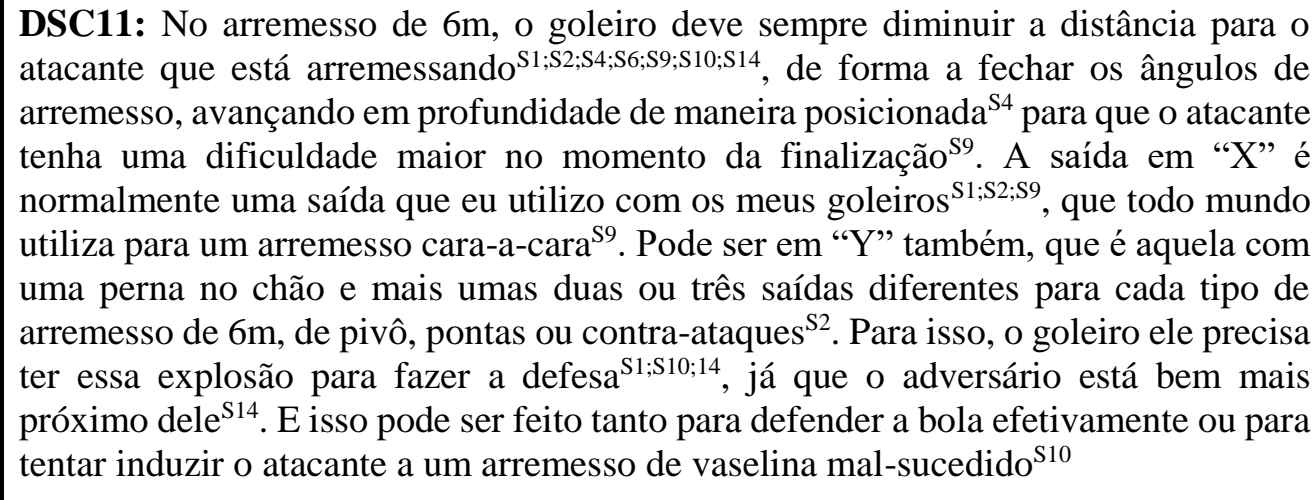 \\
\hline $\begin{array}{l}\text { IC- } \mathbf{1 2}(6 \mathbf{m}) \\
\text { Sinais } \\
\text { Relevantes para } \\
\text { a definição do } \\
\text { posicionamento } \\
\text { tático } \\
\text { (S2; S3; S6; S7; } \\
\text { S10; S11; S12; } \\
\text { S13; S14; S15; } \\
\text { S16; S17; S18; }\end{array}$ & 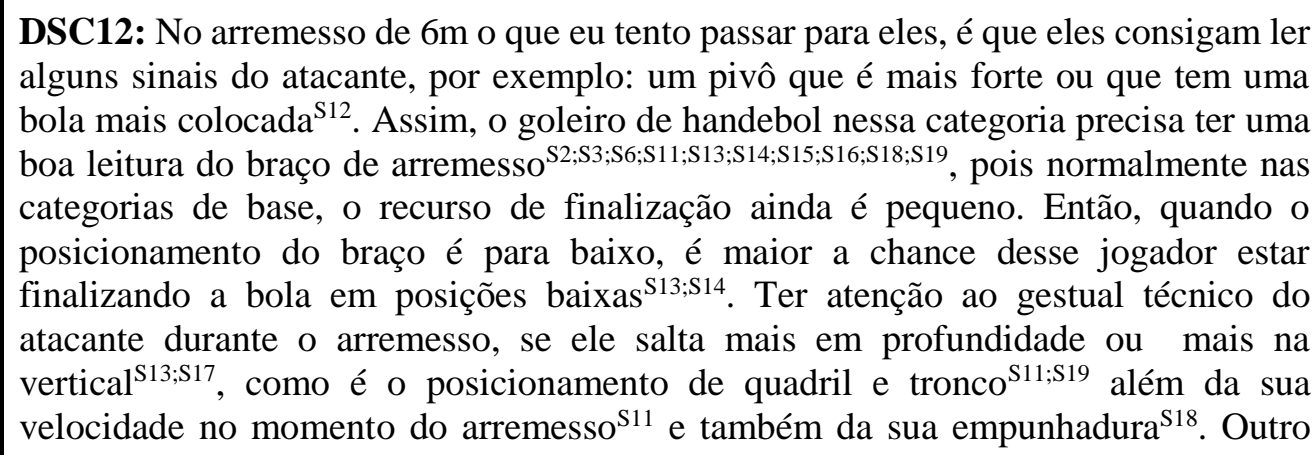 \\
\hline
\end{tabular}




\begin{tabular}{|c|c|}
\hline S19) & 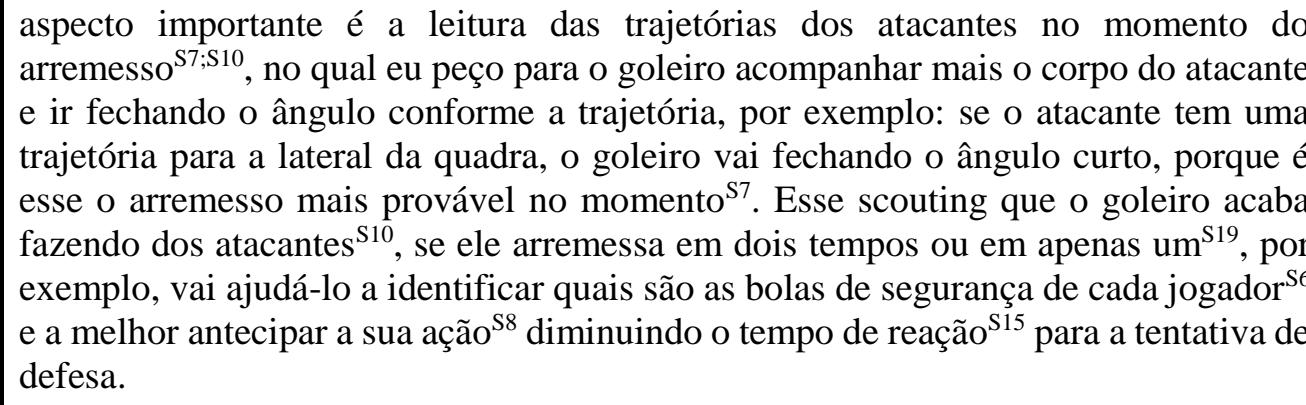 \\
\hline $\begin{array}{l}\text { IC- } \mathbf{1 3}(\mathbf{6 m}) \\
\text { Não } \\
\text { mecanização das } \\
\text { ações } \\
\text { (S5) }\end{array}$ & $\begin{array}{l}\text { DSC13: A única coisa que eu cobro dos goleiros é para que ele não mecanize os } \\
\text { movimentos. Por exemplo: arremesso de pivô com giro e salto é para ele variar as } \\
\text { estratégias. Se ele sai, talvez provoque um erro de tentativa de vaselina, se chuta } \\
\text { rápido e ele ocupa espaço, essa bola acaba batendo nele, diminuindo o ângulo do } \\
\text { atacante. Assim, eu dou algumas informações nesse sentidoss. }\end{array}$ \\
\hline $\begin{array}{l}\text { IC- } \mathbf{1 4}(\mathbf{7 m}) \\
\text { Posicionamento } \\
\text { em função da } \\
\text { estatura } \\
\text { (S1; S10) }\end{array}$ & $\begin{array}{l}\text { DSC14: Na cobrança de } 7 \mathrm{~m} \text {, se eu tenho um goleiro alto eu mando avançar até a linha } \\
\text { de } 4 \mathrm{~m}^{\mathrm{S} 1, \mathrm{~S} 10} \text {, um goleiro de altura mediana, eu mando avançar até a linha de } 2 \mathrm{~m} \text { e o } \\
\text { goleiro mais baixo vai ter que ficar em cima da linha do gol no } 7 \mathrm{~m}^{\mathrm{s} 1} \text {. Isso depende } \\
\text { muito do que a gente tem em mão, às vezes é melhor para o goleiro mais baixo brincar } \\
\text { de "ir e voltar" porque se ele ficar só em cima da linha do gol, a chance de ele defender } \\
\text { vai ser a mesmas10. }\end{array}$ \\
\hline $\begin{array}{l}\text { IC- 15 (7m) } \\
\text { Sinais } \\
\text { Relevantes para } \\
\text { a definição do } \\
\text { posicionamento } \\
\text { tático } \\
\text { (S1; S3; S4; S5; } \\
\text { S6; S7; S8; S9; } \\
\text { S10; S12; S13; } \\
\text { S14; S16; S18; } \\
\text { S19) }\end{array}$ & 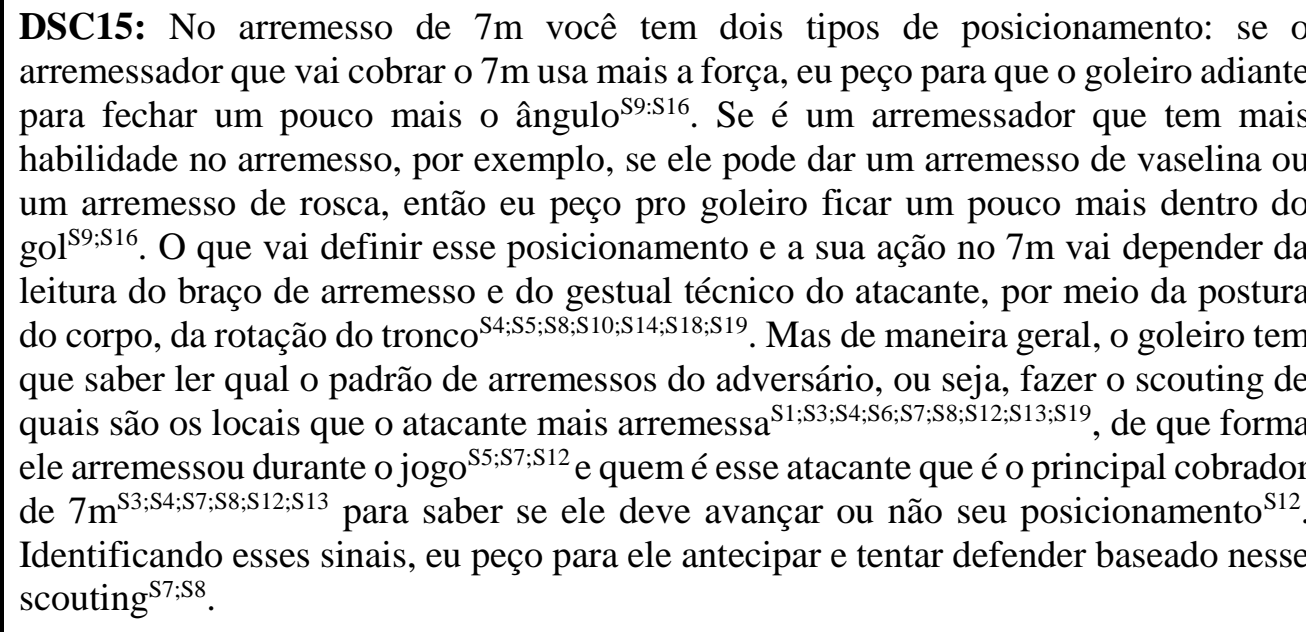 \\
\hline $\begin{array}{l}\text { IC- } \mathbf{1 6}(\mathbf{7 m}) \\
\text { Movimentações } \\
\text { e Deslocamentos } \\
\text { durante o tiro de } \\
7 \mathrm{~m} \\
(\mathrm{~S} 2 ; \mathrm{S} 10 ; \mathrm{S} 15)\end{array}$ & $\begin{array}{l}\text { DSC16: Na cobrança de } 7 \mathrm{~m} \text {, tem que ter saídas variadas }{ }^{\mathrm{S} 2 \mathrm{~S} 15} \text {. Eu treino algumas } \\
\text { saídas com cada goleiro, sendo uma mais próxima do gol e outra mais avançada } \\
\text { na qual o goleiro pode ficar se movimentando mais } \\
\text { s10 } \\
\text { você fica parado com o braços e pernas e na outra } \\
\text { baixo do gol, ele pode ficar se deslocando de uma trave a outra }{ }^{\mathrm{S} 2} \text { pora conseguir } \\
\text { chegar nas bolas }{ }^{\mathrm{S} 15}\end{array}$ \\
\hline
\end{tabular}


IC- 17 (7m)

O Feeling do goleiro

$(\mathrm{S} 4 ; \mathrm{S} 10)$
DSC17: O que eu tenho feito vai depender muito do feeling do goleiro ${ }^{510}$. No $7 \mathrm{~m}$ eu trabalho com a situação de que se o atacante não fez nenhum arremesso, o goleiro tem a liberdade de definir aonde ele se sente mais confortável, seja mais à frente ou mais atrás, deixando a tomada de decisão a cargo deles ${ }^{\mathrm{S} 4}$

\section{Leitura do Arremesso}

Diante do exposto sobre a atuação do goleiro de handebol em diferentes fases do jogo, faz-se necessário compreender o que os treinadores pensam sobre as ações do goleiro diante de arremessos de diferentes distâncias. O DSC8 apontou a importância da capacidade técnico-tática de leitura do arremesso, destacada nas situações de arremessos de longa distância, ou seja, arremessos executados com distâncias próximas ou superiores aos $9 \mathrm{~m}$ da quadra de ataque.

A capacidade de leitura do arremesso está bastante relacionada com a percepção dos sinais relevantes do ambiente do jogo para a tomada de decisão (GRECO, 1988; MATIAS; GRECO, 2010). Faz referência a capacidade que um jogador tem de "ler" o jogo e identificar os estímulos mais significantes da ação que vai ser executada pelo jogador adversário.

Especificamente sobre o goleiro, o DSC8 apontou como objetivos da leitura do arremesso, a identificação do momento exato do arremesso para que o goleiro consiga se posicionar de forma a ter vantagem para fazer a defesa. Esse posicionamento vantajoso seria possível caso o goleiro conseguisse, por meio da leitura, se antecipar à ação do atacante e se posicionar momentos antes do arremesso. Porém a ação de leitura do goleiro não pode ser muito antecipada, pelo fato de o atacante também contar com a sua capacidade de retificação do arremesso (SINGER, 1970). Este aspecto é ressaltado no final do DSC8, apontando que uma ação muito antecipada do goleiro pode dificultar a sua situação de defesa. Dessa forma, a antecipação do posicionamento do goleiro para realizar a defesa depende muito da capacidade de leitura do arremesso (SÁ; FERNÁNDEZ ROMERO; GOMES; 2007), fundamental para o seu sucesso, como discutido na seção anterior (DSC1).

A capacidade de ler os sinais que demonstram a intenção do atacante para o arremesso é um aspecto relacionado com o bom desempenho do goleiro, uma vez que o jogo de handebol tem ficado mais rápido, seja no número de ações executadas ou na velocidade com que elas ocorrem dentro do jogo (ESPINA-AGULLO et., 2016). Atualmente os arremessos das zonas centrais da quadra têm sido ainda mais difíceis de defender, principalmente pela 
velocidade da bola, o que possibilita menor tempo para leitura, posicionamento e execução das ações pelos goleiros. Especificamente nos arremessos de 9m, os goleiros têm maior tempo para reagir devido à distância da qual são realizados, o que significa que a leitura e a antecipação da ação para a defesa são fatores que podem trazer vantagens ao goleiro (ESPINA-AGULLO et., 2016).

Mesmo sendo uma capacidade que depende da experiência do atleta (SÁ; FERNÁNDEZ ROMERO; GOMES; 2007; SÁ et al., 2015; ESPINA-AGULLO et., 2016) é importante a ênfase nesses aspectos ao longo do processo de formação do goleiro, principalmente para estimulá-lo a entender: a) o que está fazendo; b) como ele vai agir; e c) porque ele tomou determinada decisão (GARGANTA, 1998). Estas indagações vão ajudar a desenvolver a dimensão tática do posto do goleiro de handebol e, talvez, contribuir para o aumento de sua efetividade.

\section{Sinais Relevantes para a definição do Posicionamento Tático do Goleiro de Handebol}

Ao ponderar sobre a importância da capacidade de leitura do goleiro frente às diferentes distâncias de arremessos, os treinadores destacaram alguns sinais relevantes que devem ser percebidos e que vão influenciar diretamente o posicionamento para a ação do goleiro em jogo.

Nesta subseção, serão discutidos três discursos (DSC9, DSC12, DSC15) referentes a cada uma das distâncias de arremesso. Percebeu-se que o braço de arremesso e as trajetórias do atacante são sinais relevantes que foram mencionadas para os arremessos de longa e curta distância, concordando com autores que apontaram essas como características gerais para a atuação do goleiro (PASCUAL FUERTES; PEÑA BARCELÓ, 2006; SÁ; FERNÁNDEZ ROMERO; GOMES, 2007). Assim, dependendo da situação de jogo, esses sinais podem se apresentar de maneiras específicas, demandando do goleiro uma capacidade de percepção para ajustar o seu posicionamento em função desses.

De acordo com Fischer et al. (1988) em situações de arremesso de longa distância o goleiro deve priorizar o seu posicionamento de frente com a linha de ação da bola. Sugere-se o posicionamento dentro da bissetriz formada pelo braço de arremesso e os dois lados do gol, o "dividindo" em ângulo curto e longo para a finalização, sendo que este último muitas vezes é preferido pelos atacantes (ARIAS ESTERO, 2009), no qual o goleiro deverá estar atento. Essa 
noção de divisão do gol em ângulos longo e curto auxilia o goleiro a se posicionar mediante o braço de arremesso e o gestual técnico empregado pelo atacante, seja em arremessos de longa distância ou de curta distância.

O DSC9 aponta que o goleiro deve ter um posicionamento mais avançado para diminuir o ângulo de arremesso do atacante. Em contrapartida, Espina-Agullo et al. (2016) aponta que em arremessos de $9 \mathrm{~m}$ os goleiros devem ter o seu posicionamento mais próximo do gol, conferindo-lhes maior tempo de reação (devido à maior distância em relação ao arremesso), o que poderia lhes trazer vantagens diante da velocidade dos arremessos. Seria interessante, nesse sentido, que o goleiro vivenciasse ao longo do seu processo de formação tais possibilidades, de modo a fornecer subsídios técnico-táticos para suas futuras atuações.

Especificamente para os arremessos dos pontas mantém-se o princípio de se posicionar de frente para o atacante, mas com especial atenção ao braço de arremesso novamente (ARIAS ESTERO; 2009). Isto ocorre devido à maior efetividade do goleiro em arremessos de $6 \mathrm{~m}$ executados nas zonas laterais do que na zona central da quadra (ESPINAAGULLO et al., 2016), pois os ângulos de arremesso tornam-se menores para o atacante, facilitando a leitura e o posicionamento do goleiro. Além disso, especialmente para os arremessos de curta distância (6m) nas zonas centrais da quadra, é preciso prestar atenção ao posicionamento do tronco do jogador adversário e procurar estar sempre entre o jogador e a sua linha de ação (ARIAS ESTERO, 2009).

Em relação às trajetórias dos atacantes e do trabalho colaborativo com a defesa, Castro d'Ávila et al. (2002) apontam que o conhecimento das características do adversário, como a sua trajetória pré-arremesso e o local de arremesso mais frequente, são informações importantes a se considerar em situações de arremesso de $9 \mathrm{~m}$ para a tomada de decisão do goleiro. Salienta-se que apesar de não ser apontado diretamente pelos treinadores do DSC12, o trabalho colaborativo com a defesa, no qual se insere a indução do arremesso em zonas laterais ou menos favoráveis para o ataque (MENEZES, 2011), pode ser considerado como uma característica importante para os arremessos de $6 \mathrm{~m}$. Tal contexto também se refere à categoria sub-16, por ser uma das características que os goleiros jovens conseguem utilizar para antecipar o arremesso (SÁ; FERNÁNDEZ ROMERO; GOMES, 2007).

As trajetórias em conjunto com o braço de arremesso podem definir os ângulos curto e longo para finalização, pois quanto mais cedo o goleiro conseguir antecipar a trajetória 
e se posicionar, maior poderá ser a sua chance de defesa. Se os defensores dificultarem as trajetórias ou limitá-las à zona lateral da quadra (com menores ângulos de arremesso), o goleiro poderá antecipar de forma mais rápida e precisa o resultado do arremesso do atacante.

Apesar da especificidade da cobrança de $7 \mathrm{~m}$, que não envolve uma trajetória do atacante pré-arremesso, existem algumas semelhanças sobre o que o goleiro deve ter atenção em relação aos arremessos de 6m. O DSC12 e o DSC15 abordaram que nessas situações de arremesso o goleiro deve ter atenção ao gestual técnico do adversário, além do movimento do braço.

Para os arremessos de $6 \mathrm{~m}$ as características do movimento do braço e da empunhadura do jogador em posse da bola são consideradas importantes para a definição do local de arremesso (ANTÚNEZ MEDINA, 2003), assim como a execução da passada trifásica e o tipo de arremesso executado (GRECO, NEVES, MATIAS, 2002). Para as cobranças de 7m aponta-se que a efetividade do goleiro vai depender, sobretudo, da relação entre a capacidade técnica do atacante que vai executar a cobrança e da capacidade de leitura do goleiro, para perceber possíveis variações de arremessos baseados na velocidade de execução da cobrança e no efeito aplicado a bola durante o arremesso (ESPINA-AGULLO et al., 2016).

Ao considerar que a velocidade de execução das ações no handebol vem aumentando nos últimos anos (ESPINA-AGULLO et al., 2016), os treinadores apontam que é importante o goleiro fazer um scouting do cobrador durante todo o jogo. Nesse scouting devem ser identificadas algumas características específicas como a zona do gol que o atacante mais finalizou e de que forma esses arremessos foram feitos ao longo do jogo, considerando as diferenças entre os arremessos de 9m, 6m e 7m. Especificamente sobre os arremessos de 7m, as características apontadas pelo DSC15 (identificação dos tipos de arremessos mais utilizados pelos cobradores e as fintas utilizadas pelos adversários para tentar confundir a leitura do goleiro) são as principais a serem observadas pelo goleiro de handebol em cobranças de $7 \mathrm{~m}$ (CASTRO D’ÁVILA et al., 2002).

Entendendo que para cada distância de arremesso vão existir algumas semelhanças e algumas diferenças entre elas, de maneira geral, diante das características apontadas pelos DSC9, DSC12 e DSC15, para ter uma maior chance de sucesso, é preciso que os goleiros desenvolvam um repertório motor capaz de subsidiar a sua capacidade de percepção e de antecipação no momento da cobrança. Esse repertório permitirá que o goleiro associe a 
execução de uma ação de defesa a um determinado sinal relevante que foi identificado durante o arremesso, seja ele direto ou com algum tipo de finta utilizada pelo atacante (ALSHARJI, WADE, 2016; LOFFING, HAGEMANN, 2014; CAÑAL-BRULAND, VAN DER KAMP, VAN KESTEREN, 2010).

\section{A Ação Defensiva em função da Velocidade dos Atacantes: Reações rápidas do goleiro de handebol}

O DSC10 aponta a importância de reconhecer a velocidade das ações na situação de jogo, para identificar quem vai executar o arremesso e em que momento isso pode acontecer durante o ataque adversário.

Como apontado na subseção anterior, o jogo de handebol tem se tornado cada vez mais rápido. Espina-Agullo et al. (2016), ao analisarem finais de Campeonatos Europeus, Mundiais e Olímpicos de 1982 até 2012, constataram que a velocidade do jogo aumentou devido ao maior número de ações ofensivas e, como consequência, um maior número de ataques ou de trocas de posse de bola, que levam a um maior número de transições. Entretanto, os autores salientam que isso ocorre devido a uma maior oposição às ações dos atacantes, o que estimula os mesmos a arremessar mais rápido e com maior potência. Logo, se a velocidade dos arremessos está aumentando como consequência de uma maior oposição do sistema defensivo, de forma a aproveitar os mínimos espaços para finalizar, o goleiro precisa estar atento à velocidade dos atacantes principalmente nos instantes que precedem o arremesso, o que segundo o DSC10 indicaria a intenção do atacante em arremessar..

Loffredo e Greco (2002) apontam que o goleiro de handebol está sujeito a uma ação de grande dificuldade por parte do adversário a cada 4 minutos aproximadamente. Dentre essas ações, segundo os autores, estão incluídas a velocidade do arremesso, o tamanho da bola e a distância em relação ao arremessador. O DSC10 aponta que para um arremesso de 9m, o goleiro deve estar atento principalmente à potência desse e à distância em que é executado. Essas características podem definir o posicionamento mais ou menos adiantado do goleiro em relação aos arremessos de longa distância $(9 \mathrm{~m})$, para além da leitura dos sinais relevantes como o braço de arremesso, as trajetórias. o trabalho com a defesa e as características individuais dos atacantes. 
Além de ter atenção na velocidade de execução dos arremessos, o goleiro também necessita reagir rapidamente, assim como abordado por Fischer et al. (1988). Os autores apontam a velocidade de reação como uma das características mais importantes para o desempenho do goleiro que, para os autores, compreende desde a capacidade de perceber os estímulos do ambiente até o momento da execução rápida da decisão tomada. Dessa forma, ser capaz de pensar em formas de treinar esse aspecto em conjunto com a capacidade de tomada de decisão, é fundamental para o desenvolvimento e bom desempenho do goleiro ao longo do processo de EAT, especialmente na categoria sub-16, na qual deveria se iniciar, de maneira mais direta, o trabalho específico com a tomada de decisão do goleiro de handebol (GRECO, 2002).

\section{Ações para diminuir o espaço do atacante no momento do arremesso}

A distância do goleiro em relação ao atacante e ao gol é um indicador que pode influenciar no posicionamento e na velocidade de reação do goleiro em arremessos de longa distância (9m) e também em arremessos de curta distância $(6 \mathrm{~m})$.

Neste caso, com o atacante mais próximo do gol, o goleiro deve se posicionar de forma a diminuir os ângulos de arremesso e fazer isso de maneira rápida, de acordo com o DSC11.

O DSC11 para os arremessos de 6m aponta, sobretudo, que o goleiro deve buscar ações que diminuam o espaço que o atacante tem para finalizar. Esse espaço está relacionado com a divisão do gol em um ângulo longo e um ângulo curto (como já abordado no DSC3 e DSC9). A partir disso, a técnica que será utilizada para diminuir a visão que o atacante tem dos ângulos de arremesso pode variar, e no DSC11 é apontada a técnica de saída em "X" como a mais comum a ser utilizada. Essa saída, consiste em avançar o posicionamento rapidamente e saltar com as pernas e os braços abertos lembrando a figura de um " $\mathrm{X}$ " para tentar ocupar o maior espaço possível do gol. Todavia, como foi apontado no próprio discurso, há muitas variações dessas saídas para diminuir o espaço do atacante. A forma técnica a ser utilizada vai depender do que o goleiro consegue executar e da forma como o treinador o prepara para esse tipo de situação, considerando as possibilidades de arremesso dos 6m, sendo os arremessos de pivô, pontas, infiltrações dos armadores e contra-ataques. 
Zeir (1981) aponta que em relação ao arremesso de 6m, seja de pivô, ponta ou de contra-ataques, parte-se do mesmo princípio: diminuir e fechar os ângulos de arremesso do atacante. $\mathrm{O}$ que vai diferenciar nestas situações, são as especificidades da posição em quadra e a forma como cada jogador atua no seu posto específico. Por exemplo: o pivô normalmente é um jogador que joga de costas ou de lado para o gol e, por isso, quando consegue girar e se posicionar de frente para o gol tem pouco tempo para realizar o arremesso. Assim, se o goleiro for capaz de avançar o seu posicionamento antes do pivô se posicionar para finalizar, pode conseguir uma vantagem (ZEIR, 1981).

Da mesma forma, Espina-Agullo et al. (2016) constataram que para os arremessos de $6 \mathrm{~m}$ executados nas zonas laterais, como os arremessos da ponta, os goleiros tiveram maior efetividade. Os autores acreditam que por se tratar de um arremesso da zona lateral da quadra, o atacante depara-se com um ângulo reduzido de arremesso (de acordo com o posicionamento do goleiro), diminuindo suas possibilidades de finalização a gol, favorecendo o goleiro na tentativa de defender a bola (ESPINA-AGULLO et al., 2016).

Mais uma vez, a forma como o goleiro vai reagir para diminuir o ângulo do atacante vai depender de alguns sinais, como a situação da bola, se está alta ou baixa ou se o atacante salta ou não para arremessar, fornecendo indicativos ao goleiro se o mesmo deve realizar uma ação de defesa saltando ou não (ZIER, 1981; FISCHER et al., 1988).

Fischer et al. (1988) apontam que mais importante do que o gesto técnico para executar a ação é a capacidade do goleiro de realizar o seu posicionamento de pré-defesa, que indicaria ao goleiro as possibilidades de ações defensivas frente o arremesso, além de induzir o próprio atacante a finalizar na zona preferida pelo goleiro ou tentar um outro tipo de arremesso (arremesso de rosca, por exemplo), com uma maior chance de erro. Por exemplo: se um pivô gira para fazer o arremesso e o goleiro já avança o seu posicionamento, pode induzir o atacante a tentar um arremesso por cobertura malsucedido, como aponta o DSC11. No entanto, deve-se treinar este tipo de ação da pré-defesa, uma vez que se for executado muito antecipadamente permite ao atacante retificar o arremesso e diminuir as chances de defesa pelo goleiro (ZEIR, 1981). 
Não Mecanização das Ações Defensivas do Goleiro de Handebol

Como apresentado anteriormente, a capacidade de leitura do arremesso é importante para que o goleiro consiga identificar alguns sinais relevantes para orientar o seu posicionamento e as suas ações de defesa. No entanto, é preciso também ter cuidado para não mecanizar as ações do goleiro, executando sempre o mesmo movimento em qualquer situação, como apontado anteriormente pelo DSC3.

Sobre este aspecto, o DSC13 apontou para os arremessos de 6m, que há uma preocupação com a reprodução de técnicas sem entender a razão de utilizá-las e que esse tipo de comportamento pode prejudicar o desenvolvimento da capacidade de antecipação do goleiro de handebol. Isto pode ocorrer pois quando o goleiro repete sempre a mesma ação, sem considerar, os sinais relevantes, este pode diminuir sua chance de responder de forma eficaz.

De acordo com Greco e Benda (2002), a ideia principal da formação do goleiro de handebol deve passar pela multiplicidade de experiências motoras e cognitivas, estimulando sua adaptabilidade na execução das técnicas de defesa e em sua capacidade de tomada de decisão frente às situações do jogo. Dessa forma, não se deve enfatizar a repetição de gestos estereotipados, como técnicas de saída em "X", em "Y" ou qualquer outra, sem entender o porquê está fazendo aquilo (GRECO; BENDA, 2002).

A ideia do processo de EAT deve ser a de possibilitar ao goleiro uma compreensão sobre o jogo na qual consiga decidir o que vai fazer sem automatizar as suas ações técnicas. O goleiro deve ser capaz de pensar, deve ser um jogador inteligente (GRECO, 1988) e capaz de tomar decisões baseadas na sua capacidade de leitura da situação de jogo, por meio de sinais relevantes que possam indicar o resultado do arremesso e favorecer a antecipação do posicionamento do goleiro.

\section{O posicionamento do goleiro em função da sua estatura}

Em relação às cobranças de 7m, nas quais não há progressão ou trajetória específica dos atacantes, algumas características podem influenciar de maneira bastante específica no processo de tomada de decisão do goleiro. De acordo com o DSC14, a estatura do goleiro pode ser um fator determinante para o posicionamento a ser adotado no momento da cobrança do tiro de $7 \mathrm{~m}$. 
O fator estatura, por ser uma característica antropométrica, não apresenta-se como treinável e, nesse sentido, o que se pretende discutir é se os goleiros considerados altos têm, realmente, melhor desempenho do que os goleiros considerados baixos. Entretanto, ao compararem o desempenho em testes motores de goleiro altos com goleiros baixos Justin et al. (2013) perceberam que não houve diferença entre os dois grupos e indicaram que poderia ser interessante uma escolha por goleiros mais altos pela sua envergadura e pelo tamanho de seus segmentos corporais, o que permitiria cobrir uma maior parte do gol. Porém, os mesmos autores salientam a necessidade de analisar o desempenho dos goleiros em jogo e indicam que os goleiros mais baixos, mas com excelentes níveis de desempenho de suas habilidades motoras e técnico-táticas, não devem ser excluídos do processo de formação esportiva (JUSTIN et al., 2013).

Percebe-se que a estatura em si não é um fator determinante no desempenho, até mesmo pelas características antropométricas de diferentes populações, o que dificulta encontrar goleiros com médias de altura elevadas em qualquer região (JUSTIN et al., 2013). Por não apresentar diferenças entre os goleiros altos e baixos, os treinadores acabam preferindo os goleiros mais altos (JUSTIN et al., 2013), como é apontado também pelo DSC14 sobre o tiro de $7 \mathrm{~m}$. Ressalta-se, portanto, que o importante é a forma como os goleiros são treinados para que o seu desempenho seja realmente efetivo

Na cobrança de $7 \mathrm{~m}$ é permitido ao goleiro se posicionar até a linha de $4 \mathrm{~m}$ dentro de uma área demarcada de $6 \mathrm{~m}$. No entanto, esse pode adotar qualquer posicionamento ou movimentação dentro deste espaço, o que o possibilita pensar em diferentes estratégias para defender cada cobrança, de acordo com as características do jogador que a executa (FISCHER et al; 1988).

Nesta situação importa que o goleiro defina a sua pré-defesa antes do momento do arremesso, para reduzir o número de ações possíveis do atacante e reagir de forma mais rápida e efetiva (FISCHER et al., 1988). As possibilidades de ações de pré-defesa do goleiro podem variar entre um posicionamento mais avançado e estático e um posicionamento mais baixo e com maior mobilidade, por exemplo. Independente da estratégia a ser escolhida, esta deve se basear nas características dos atletas, como a estatura. É importante, ainda, que o goleiro consiga manter uma posição relaxada e seja capaz de identificar o que os adversários vão fazer no momento da cobrança do 7m (FISCHER et al., 1988; ESPINA-AGULLO, 2016). 
Movimentações e Deslocamentos durante o Tiro de $7 \mathrm{~m}$

Considerando os fatores que influenciam no posicionamento do goleiro em um tiro de $7 \mathrm{~m}$, como a estatura, o conhecimento do atacante que executa a cobrança, além do regulamento que permite o goleiro avançar até a linha de $4 \mathrm{~m}$, pode se dizer que a situação do tiro de $7 \mathrm{~m}$ é complexa por ser influenciada por diversos fatores. Assim, criar estratégias para fintar o atacante e induzi-lo ao erro, torna-se importante para pautar a atuação do goleiro nesse tipo de situação.

A finta é um meio técnico-tático individual do goleiro de handebol (BENDA; XAVIER; MARTINI, 2002) utilizado para induzir os atacantes a arremessar a bola em uma zona na qual esse já está preparado para reagir. O DSC16 aponta a necessidade em desenvolver variadas formas de posicionamento na cobrança de $7 \mathrm{~m}$, especialmente aquelas que envolvem alguma movimentação ou tentativa de finta do goleiro.

Sobre o comportamento do goleiro em uma cobrança de 7m, Fischer et al. (1988) apontam que esse pode ter vantagem caso execute uma ação de finta bem-sucedida, como se posicionando mais para o lado direito e deixando o lado esquerdo do gol mais aberto. Porém, é preciso ter atenção para que não se conceda vantagens muito amplas ao atacante, principalmente no que se refere à tomada de decisão muito precoce ou, no caso do exemplo anterior, não deixar um dos lados do gol sem qualquer tipo de proteção, o que dificultará a tentativa de defesa (FISCHER et al., 1988).

As fintas podem ser variadas, desde que cumpram com o seu objetivo principal. No DSC16, os treinadores apontam características de dois tipos de finta para o goleiro: uma de movimentação dos braços e pernas, tentando confundir o atacante sobre qual vai ser o gesto técnico que o goleiro vai executar, e outra que se refere à finta de deslocamento, na qual o goleiro se posiciona em cima da linha do gol e fica se deslocando de um lado para o outro (o que também pode ser realizado com o goleiro mais avançado), consideradas mais eficazes por Greco, Neves e Matias (2002).

Pensando na categoria sub-16 é interessante estimular os goleiros a pensar em diversas possibilidades de posicionamento em um tiro de $7 \mathrm{~m}$ ou, ainda, estimulá-los a criar possíveis fintas para que o atacante não consiga retificar o arremesso, diminuindo a sua precisão. Assim como Loffredo e Greco (2002) abordaram, a boa execução da finta para um 
goleiro na cobrança de $7 \mathrm{~m}$ vai ser aquela que o goleiro consiga fazer o movimento de engano e tenha condição de voltar à posição inicial para então reagir e conseguir defender o arremesso.

\section{O feeling do goleiro}

O DSC17 considera que em alguns casos, quando não se conhece o atacante que cobrará o 7m, a decisão sobre a estratégia a ser utilizada vai depender do que o goleiro se sente seguro em fazer, de acordo com o seu nível de desempenho técnico-tático, buscando uma "zona de conforto" para definir a sua ação. Dessa forma, os treinadores apontam para a importância de reconhecer ofeeling do goleiro no momento da cobrança de $7 \mathrm{~m}$, termo da língua inglesa que traz a ideia de sensação, sentimento.

A menção do feeling atinge uma dimensão psicológica-emocional da preparação do goleiro de handebol, o que não a torna menos importante do que as demais características. Pelo contrário, segundo Greco, Neves e Matias (2002) em uma cobrança de $7 \mathrm{~m}$ o vencedor da disputa goleiro x atacante será aquele que estiver melhor psicologicamente preparado. Isto não quer dizer que as demais características não são importantes, mas se ambos os jogadores estivessem no seu ápice físico e técnico-tático, a confiança naquilo que já se sabe, ou em outras palavras, ofeeling pode determinar quem terá mais vantagem nessa situação.

É preciso saber que o feeling, enquanto conjunto de experiências que levam o goleiro a ter um conhecimento mais amplo das situações de jogo, não é uma características inata, sendo construído a partir das experiências vividas pelos atletas no ambiente de jogo. Isto quer dizer que para construir o feeling do goleiro, para que ele possa ter autonomia em suas decisões, é necessário que o mesmo tenha uma boa base técnico-tática e um bom treinamento perceptivo e de tomada de decisão, especialmente em situações de pressão, como é uma cobrança de $7 \mathrm{~m}$ (ZEIR, 1981).

O feeling do goleiro nesse caso, representa todo um acervo de experiências vivenciadas pelo atleta, que em uma determinada situação, como a exemplificada no DSC17, de quando o goleiro não conhece o jogador que vai executar a cobrança de $7 \mathrm{~m}$, possa decidir pela ação que acredita ser mais efetiva, sem a intervenção do treinador. Ele pode fazer isso por meio de uma finta para observar a reação do atacante, pode avançar o seu posicionamento ou ficar deslocando-se para frente e para trás. O importante é, em uma situação de pressão, como 
é uma cobrança de $7 \mathrm{~m}$, manter-se calmo e confiante antes e depois do arremesso (FISCHER et al., 1988).

O objetivo deste capítulo foi apresentar os discursos dos treinadores entrevistados que abordaram os indicativos para as ações do goleiro de handebol na categoria sub-16. Os DSC apresentados apontaram algumas ações que o goleiro pode realizar em relação a fase ofensiva, especificando algumas ações de acordo com a distância de arremesso e em relação as fases defensiva e ofensiva do jogo, como sumário representado na Figura 7.

Figura 7. Indicativos de ação do goleiro de handebol na categoria sub-16 baseado na opinião dos treinadores entrevistados

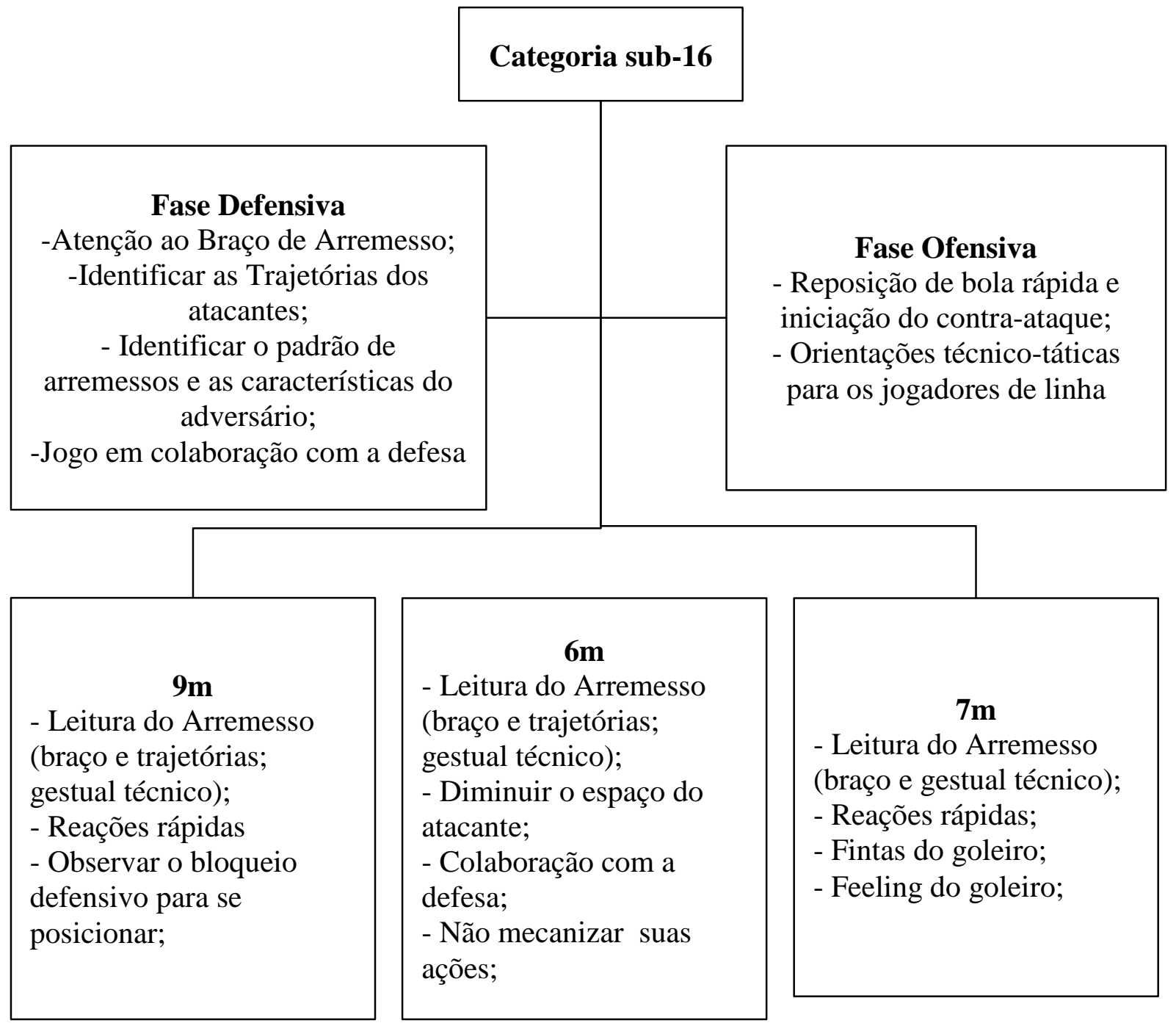


CAPÍTULO 4 - CARACTERÍSTICAS QUE SUPORTAM AS AÇÕES DO GOLEIRO DE HANDEBOL

Foi apresentado no capítulo anterior a discussão sobre as ações do goleiro de handebol na categoria sub-16 em situação de jogo, de acordo com as fases de jogo e diante das diferentes distâncias de finalização. Muitas ações foram indicadas pelos treinadores como sendo essenciais para o desempenho do goleiro, o que torna importante discutir as características que podem suportar essas ações no contexto de formação esportiva.

Neste capítulo, serão apresentados os discursos de outras duas questões do instrumento de entrevista. A primeira delas questionou o treinadores sobre quais seriam as características técnico-táticas mais importantes para o goleiro sub-16, que pudessem suportar suas ações em jogo, discutidas no capítulo anterior. A segunda questão teve por objetivo perguntar aos treinadores sobre as características essenciais para a especialização do goleiro.

\section{AS CARACTERÍSTICAS TÉCNICO-TÁTICAS NA FORMAÇÃO DO GOLEIRO DE}

\section{HANDEBOL}

No Quadro 8 são apresentados os DSC referentes às opiniões dos treinadores entrevistados acerca das características técnico-táticas mais importantes para a formação do goleiro de handebol na categoria sub-16.

Quadro 8. IC e DSC referentes à questão: “Quais são as principais capacidades técnicotáticas a serem desenvolvidas pelo goleiro de handebol na categoria sub-16? Que patamares você espera que essas capacidades alcancem?"

IC- 18 Posiçãobase e as características técnicas do goleiro (S1; S3; S4; S5; S6; S7; S8; S9; S10; S11; S12; S13; S14; S16; S17; S18; S19)
DSC18: No sub-16, quando se fala em capacidade técnica de um goleiro, ele tem que saber perfeitamente a execução de um deslocamento para uma defesa baixa, para uma defesa meia-altura e para uma defesa alta S1; S4; S11; S12; S13; S14; S19. Além disso, o trabalho postural, a posição base do goleiro com o braço alto e o corpo sempre estendido são muito importantes para que ele tenha um bom posicionamento em relação a bola S1; S3; S4; S5; S6; S10; S11; S18; S19, em relação a trave com os ângulos longo e

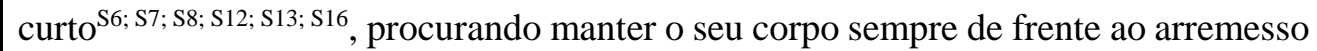

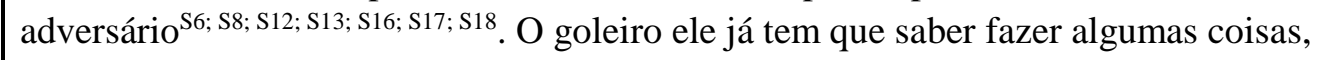
como uma queda, um espacato, um " $X$ " bem feito, atacar a bola, ter essa noção de saídas para defender a bola $\mathrm{S1}$; $\mathrm{S3}$; $\mathrm{S5}$; $\mathrm{S7}$; $\mathrm{S11}$; $\mathrm{S13}$, isso somado a um bom trabalho coordenativo para economizar energia ${ }^{510}$. Na parte ofensiva, ele tem que ter um bom 


\begin{tabular}{|c|c|}
\hline & 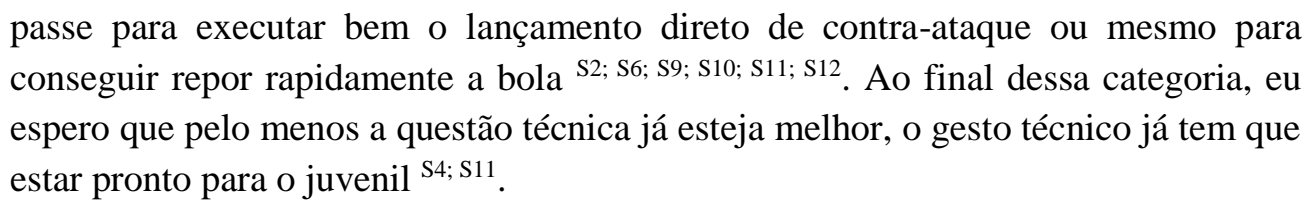 \\
\hline $\begin{array}{l}\text { IC- } 19 \\
\text { Tomada de } \\
\text { decisão } \\
\text { (S1; S2; S3; S4; } \\
\text { S5; S6; S7; S9; } \\
\text { S10; S13; S14; } \\
\text { S16; S17) }\end{array}$ & 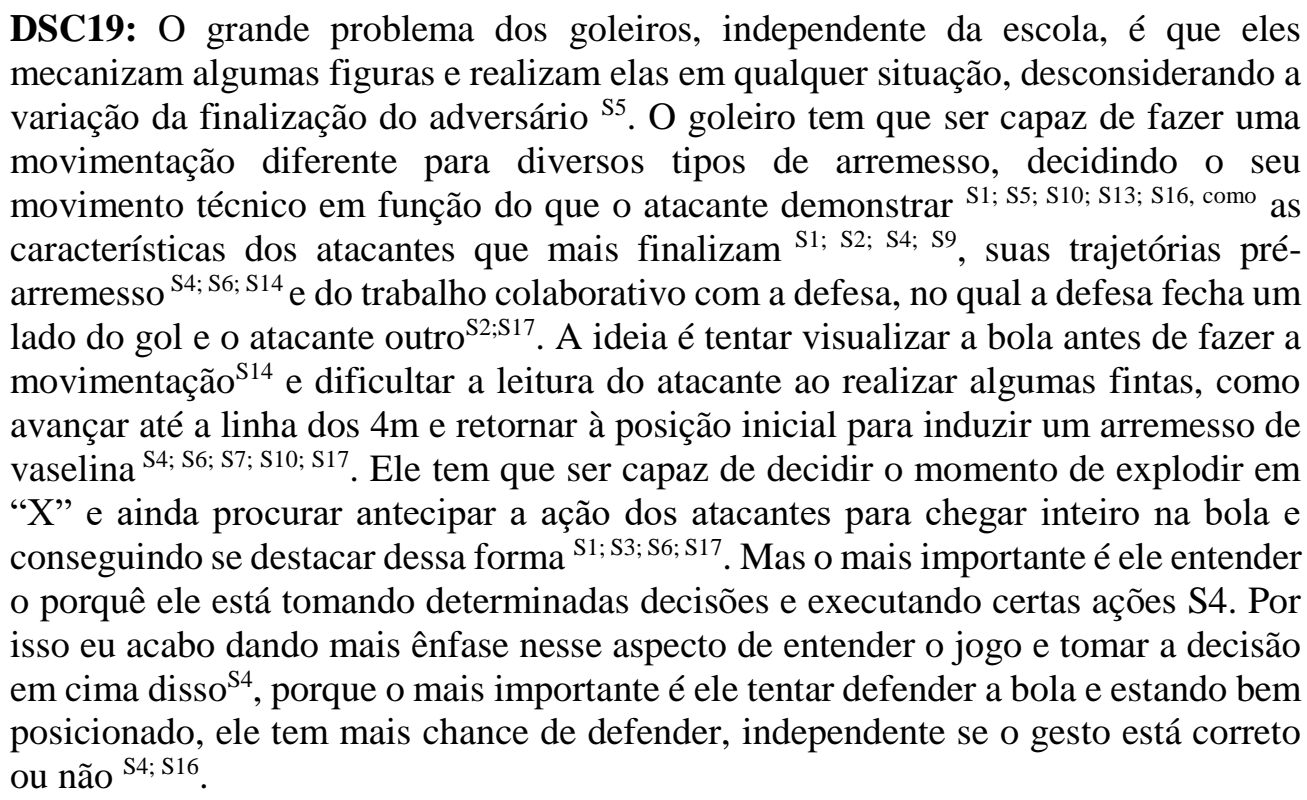 \\
\hline
\end{tabular}

\section{Posição-base e características técnicas do goleiro de handebol}

O goleiro de handebol apresenta características técnicas específicas que o diferencia dos demais jogadores. Características essas que vão dar o suporte necessário para a execução das tomadas de decisão ao longo do jogo.

No DSC18 os treinadores apontam como características técnicas importantes para o goleiro de handebol da categoria sub-16: a posição-base do goleiro, as técnicas de defesa (alta, baixa e meia-altura), saída em "X" e "espacato" e o passe para repor a bola em jogo ou para fazer o lançamento direto para o contra-ataque.

Singer (1970) aponta que, dentre outras características, o goleiro possui suas missões técnicas (grifo do autor) que consiste no domínio dos deslocamentos para se posicionar no gol e das diferentes técnicas de defesa. Essas características técnicas o ajudam a reduzir os ângulos de arremesso dos atacantes e conseguir defender os arremessos em diferentes alturas no gol. Segundo Zeir (1981) a técnica específica permite reduzir o número de decisões que o goleiro pode tomar em pouco tempo, uma vez que poderá selecionar somente movimentos que 
aprendeu. Para isso é necessário considerar as características individuais do goleiro, de forma a realizar as adaptações necessárias na execução dos movimentos, desconsiderando a ideia de uma técnica fixa, mas sendo vista como individualmente construída (ZEIR, 1981; LOFFREDO; GRECO, 2002; THIENGO; VITÓRIO; FERREIRA, 2006; ARIAS ESTERO, 2009).

O DSC18 indica a necessidade de dominar a execução das técnicas de deslocamento para os arremessos de bolas altas, meia altura e bolas baixas. Mas para que se atinja o domínio desejado, destaca-se a importância de um trabalho postural e da posição base do goleiro de handebol. A posição base é a forma como o goleiro se mantém posicionado, de maneira esteja apto a reagir para qualquer lado e altura, dependendo dos sinais do arremesso adversário (LOFFREDO; GRECO, 2002), permitindo movimentos de defesa com rapidez, com saídas e saltos em equilíbrio a partir de um posicionamento perpendicular à trajetória da bola (ZEIR, 1981). Tal posição consiste em manter braços e pernas em semi-flexão, preparando-os para a extensão no momento da ação defensiva; tronco ligeiramente inclinado à frente e mantendo uma posição estável, dividindo o peso corporal de maneira uniforme em ambas as pernas e voltando as mãos para a bola (LOFFREDO; GRECO, 2002; THIENGO; VITÓRIO; FERREIRA, 2006; ARIAS ESTERO, 2009).

A descrição da posição-base do goleiro de handebol encontrada na literatura é semelhante quanto aos objetivos, mas difere em alguns aspectos quando comparamos com o DSC18, que aponta a necessidade de manter braços sempre altos e o corpo estendido. A concepção generalista sobre a posição-base do goleiro apresentada pelos treinadores, desconsidera as aptidões individuais do atleta, como os fatores antropométricos e a própria especificidade da execução técnica. Isto pode levar a um modelo de goleiro pouco eficaz do ponto de vista técnico-tático para responder às demandas impostas pelas situações do jogo, uma vez que não há necessidade, por exemplo, de se manter os braços sempre altos, quando há indicação de que o arremesso será feito na parte baixa do gol; ou de manter os braços sempre estendidos reduzindo sua mobilidade. O mau posicionamento dos braços, juntamente com o desequilíbrio no momento de um salto para tentar defender a bola, são os erros mais recorrentes na execução da posição-base do goleiro de handebol (ZEIR, 1981).

Além da posição-base, o DSC18 aponta que o goleiro deve ser capaz de executar outras ações técnicas para conseguir realizar a defesa da bola, como uma defesa em espacato, 
uma defesa em "X", ter noções de avanço e retorno de posicionamento e também os deslocamentos para a defesa.

Quanto aos deslocamentos, a ideia consiste em estar posicionado e identificar qual será a ação do atacante com bola, para então deslocar-se rapidamente para o local do gol onde será feito o arremesso, tentando manter a posição de base sempre que possível (LOFFREDO; GRECO, 2002). Arias Estero (2009) aponta que existem quatro tipos de deslocamentos fundamentais: a) aquele em que o goleiro se desloca em posição-base de um lado ao outro do gol para acompanhar a movimentação da bola; b) aquele em que o goleiro tem que buscar defender o lado do gol para onde foi feito o arremesso, configurando uma ação de despeje (grifo do autor), na qual o goleiro deve buscar impedir que a bola entre no gol e não necessariamente segurá-la; c) aquele em que o goleiro executa após um despeje, para retomar a posse da bola quando a mesma está dentro da área do goleiro; e por último, d) após uma ação de defesa, o goleiro deverá retomar a sua posição habitual no gol, procurando retomar o equilíbrio do seu posicionamento principalmente em caso de rebote que permaneça com o atacante.

No DSC18 os treinadores também apontam o lançamento da bola para um contraataque direto e a reposição de bola rápida como ações técnicas de responsabilidade do goleiro de handebol. Essas são duas características apontadas como fundamentais para o bom desempenho individual ofensivo do goleiro (ANTÚNEZ MEDINA, 2003), que deve ser capaz de repor a bola em jogo rapidamente e estar atento para fazer o lançamento de contra-ataque direto ou iniciá-lo de maneira sustentada (MENEZES, 2011).

Nesse contexto, o domínio da posição-base e das ações de deslocamento para a defesa são características técnicas fundamentais para o bom desempenho do goleiro. Quanto a esse aspecto, pode-se dizer que o DSC18 concorda com diferentes autores, apesar de apresentar perspectiva contrária em relação a padronização da posição-base sem considerar as características individuais dos atletas e a situação de jogo, a qual pode influenciar diretamente na posição adotada pelo goleiro para tentar fazer a defesa.

A posição-base do goleiro não deve ser comum a todos os atletas, pois possuem características diferentes (como as antropométricas e as motoras), que podem influenciar, por exemplo, na altura em que os goleiros posicionam o seu braço. Por outro lado, pode não ser vantajoso para um goleiro de estatura baixa manter seus braços em extensão total, pois poderá perder mobilidade em seus deslocamentos e prejudicar seu desempenho. Sugere-se enfatizar 
durante o processo de EAT que essa posição não é fixa e deve considerar também os sinais relevantes da situação de jogo, que podem alterar a forma como o goleiro se prepara para tentar defender um arremesso.

O trecho final do DSC18 aponta o que os treinadores esperam que o seus atletas saibam fazer ao final da categoria sub-16, enfatizando o domínio das técnicas de defesa. Considerando que a categoria sub-16 é apontada como o início da fase de especialização deste posto específico (GRECO; BENDA, 2002), parece contraditória a opinião dos treinadores de que ao final da categoria os goleiros tenham que dominar todas as técnicas de defesa. Se pensarmos na execução do movimento, pode até ser que os atletas consigam, no entanto, há que se considerar os aspectos cognitivos e de tomada decisão vinculados à execução da técnica para que a mesma tenha efeito e seja aplicada no momento correto.

Além disso, deve-se considerar que muitos atletas iniciam a sua trajetória esportiva nessa categoria, sem uma base de coordenação motora específica abordada nas categorias anteriores, o que por si só dificulta a construção das técnicas de defesa. Isso não quer dizer que o goleiro não terá sucesso, pois se for capaz de entender o jogo e os conceitos principais do posto específico, como se manter sempre entre a bola e o alvo e procurar evitar que bola entre no gol, independentemente do gesto técnico que execute, o goleiro poderá ser efetivo em suas ações. Talvez, pensar em um domínio técnico somente a partir da categoria sub-18 e início da categoria sub-21, com a consolidação do processo de especialização esportiva (GRECO; BENDA, 2002).

\section{A Tomada de Decisão do Goleiro de Handebol}

Desenvolver a capacidade técnica do goleiro de handebol a partir de diferentes situações de jogo respeita o contexto no qual esse tomará suas decisões. Essa perspectiva visa dar suporte ao desenvolvimento do jogo tático do goleiro, que o permite escolher dentre as ações técnicas que sabe executar para responder a uma situação de jogo específica.

Todavia, mais importante do que o "como", é entender o "porquê" e "quando" uma determinada ação técnica deve ser adotada e em quais situações ela pode responder de forma eficaz. Nesse âmbito, o DSC19 apresentou os aspectos que levam os goleiros da categoria sub16 a tomarem decisões sobre suas ações defensivas e a importância desses aspectos no seu desempenho. 
As ações técnico-táticas apresentadas pelo DSC19 fazem referência ao processo de tomada de decisão do goleiro de handebol, no qual este deve ser capaz de combinar suas ações técnicas com o entendimento do jogo, a partir do envolvimento de características cognitivas que permitam ao atleta deste posto específico entender quando, como e porque ele deve tomar determinada decisão (GARGANTA, 1998).

Primeiramente, é preciso definir o que é tomada de decisão e os processos que estão subjacentes a isto. Segundo Matias e Greco (2010), a tomada de decisão no esporte pressupõe selecionar uma resposta em um ambiente com várias respostas possíveis, baseada na capacidade de perceber estímulos do jogo, recorrer a uma memória de ação para saber qual técnica é a melhor para resolver determinado problema e, assim, procurar antecipar a ação em relação ao movimento do adversário para se ter vantagem. Os processos subjacentes estão relacionados com: a capacidade de percepção, que envolve identificar os sinais relevantes da situaçãoproblema; a capacidade de atenção, que especifica qual o estímulo mais importante a se perceber no momento; a memória, na qual ao identificar um estímulo, verifica se o mesmo já foi vivenciado antes e como se deu a resposta; e a antecipação, que é processo de tentar reagir frente a uma situação, pouco tempo antes que ele ocorra, de forma a ter vantagem para se defender da mesma (MATIAS; GRECO, 2010).

Como resultado de um processo de EAT, no qual o jogador é estimulado a ser crítico e a entender a razão do porquê executar determinada ação, a tomada de decisão auxilia o goleiro, impedindo a execução de ações técnicas sem entender quais os estímulos da situação de jogo e que tipo de ação técnico-tática é necessária para responder de forma efetiva à uma situação específica (PASCUAL FUERTES; PEÑA BARCELÓ, 2006). O DSC19 corrobora a ideia supracitada, apontando como grande problema a mecanização dos gestos técnicos em qualquer situação, sem considerar as variações das finalizações dos atacantes.

O trecho seguinte do DSC19, indica algumas características a serem consideradas para tomar a decisão e tentar fazer a defesa. Algumas dessas já foram discutidas em outras seções, como os tipos de arremesso de cada atacante, suas trajetórias e posicionamento em quadra no momento do arremesso para definir os ângulos longo e curto, identificar o momento de avançar e os melhores momentos para tentar uma defesa em " $X$ " ou mesmo utilizar uma finta contra o atacante. De maneira geral, envolvem a capacidade de percepção do ambiente e atenção aos sinais mais importantes do jogo, muito relacionada com a percepção dessas 
características citadas e a antecipação das respostas para tentar defender. Por meio da leitura dos sinais relevantes do atacante, o goleiro pode pensar em estratégias para induzir o atacante a agir como ele deseja, por exemplo, com a utilização de fintas, o que torna imprescindível o treinamento das capacidades de percepção e antecipação para o goleiro de handebol, em especial, na categoria sub-16 (GRECO; BENDA, 2002).

Existem algumas propostas de treinamentos denominados perceptivos-decisionais para o goleiro de handebol, que são pautados na identificação de certos estímulos que podem definir qual ação o goleiro deverá executar. Pascual Fuertes e Peña Barceló (2006) apresentaram uma proposta de treinamento baseado nas capacidades perceptiva e antecipatória diante de arremessos da primeira linha ofensiva $(9 \mathrm{~m})$. O treino baseou-se em estruturar os estímulos dividindo o arremesso em 4 fases (inicial, ataque, execução e resultado), e em cada uma dessas, o goleiro deveria observar determinados sinais para começar a preparar sua estratégia de defesa. Em um estudo posterior (PASCUAL FUERTES, 2007) foi proposto um modelo de treinamento para o goleiro de handebol baseado no tempo total de ação do goleiro, definindo em três subtempos: prévio a soltura da bola da mão do jogador; tempo de voo da bola até chegar ao goleiro e o tempo de chegada da bola no goleiro. Em cada subtempo, haveriam critérios a se observar para definir a decisão do goleiro.

Em outro estudo, Antúnez Medina et al. (2010) desenvolveram uma proposta de treinamento perceptivo-motor para uma goleira de handebol, de acordo com a situação e o posicionamento do atacante em quadra. Ao final do treinamento, verificou-se por meio da utilização de planilhas de análise a partir de um protocolo específico de observação de jogos ao vivo ou por vídeo, que a goleira submetida ao modelo de treinamento, melhorou sua eficácia em competição.

Independentemente das propostas, o objetivo final era melhorar as capacidades envolvidas na tomada de decisão do goleiro, permitindo que esse fosse capaz de identificar os estímulos e de se antecipar a eles, para obter vantagem. O que valida o discurso dos treinadores no DSC19, quando dizem que o goleiro deve visualizar a bola antes de fazer a movimentação. Entende-se que não é somente a bola que deve ser observada, pois há outras características já discutidas que influenciam o arremesso. Mas percebe-se que há uma preocupação por parte dos treinadores em enfatizar os aspectos relacionados às capacidades que envolvem a tomada de decisão em situação de jogo na categoria sub-16. 
Entende-se que por se tratar de capacidades que melhoram com o tempo e com a experiência (SÁ et al., 2015) é necessário que se inicie este trabalho ainda cedo e principalmente no momento de especialização da posição, pois são capacidades fundamentais para, como mencionado no trecho final do DSC19, entender as ações que acontecem em jogo e o porquê está tomando determinada decisão.

Dessa forma, para o treinamento da tomada decisão do goleiro na categoria sub-16, seja para arremessos de primeira ou segunda linha ofensiva, considerando aspectos como a posição do braço de arremesso, trajetórias dos atacantes, entre outros, é necessário que esse treinamento enfatize as informações para que o goleiro antecipe a ação do atacante, o que significa apresentar ao atleta os aspectos preponderantes para que consiga planejar e executar a ação de defesa (PASCUAL FUERTES; PENÃ BARCELÓ, 2006). Além disso, deve-se pensar em planejar tarefas que estimulem os processos subjacentes à tomada de decisão do goleiro, sem excluir o trabalho técnico, mas de modo que possa integrá-lo ao estímulo decisional, o que vai ajudar na melhora da reação do goleiro (HELM; REISER; MUNZERT, 2016).

\section{AS CARACTERÍSTICAS CONSIDERADAS PARA A ESPECIALIZAÇ̃̃O DO GOLEIRO DE HANDEBOL}

O desenvolvimento da posição-base e das técnicas de defesa baseadas no processo de tomada de decisão em situação de jogo é que oferece suporte às ações do goleiro de handebol. Todavia, é necessária uma reflexão que permita identificar as principais características para estruturar o processo de especialização do goleiro.

No Quadro 9, foram discutidos os discursos relacionados com as características mais relevantes para a especialização do goleiro de handebol, pensando na categoria sub-16.

Quadro 9. IC e DSC referentes à questão: "Quais as características que você considera para a especialização do goleiro de handebol?"

IC- 20

Estatura e envergadura (S1; S2; S3; S7; S8; S9; S10; S11; $\mathrm{S} 13 ; \mathrm{S} 14 ; \mathrm{S} 15$; $\mathrm{S} 17 ; \mathrm{S} 18)$
DSC20: Se fosse para falar daquilo que eu gostaria de ter nos meus goleiros, seria

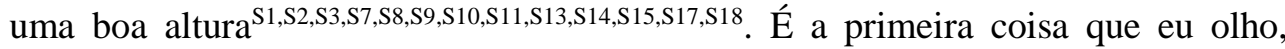
porque o goleiro não pode ser muito baixo, senão fica muito difícil ${ }^{\mathrm{S} 1, \mathrm{~S} 8, \mathrm{S17}}$. Alguns aspectos físicos são desejáveis, para além da altura, é importante também o goleiro ter uma boa envergadura ${ }^{\mathrm{S} 7 \mathrm{~S} 13}$. 


\begin{tabular}{|c|c|}
\hline $\begin{array}{l}\text { IC- } 21 \\
\text { Desenvolvimento } \\
\text { do Repertório } \\
\text { Motor } \\
\text { (S2; S4; S5; S6; } \\
\text { S12; S15) }\end{array}$ & $\begin{array}{l}\text { DSC21: Primeiro eu acho que tem que partir da criança } \$ 15 \text {. Na base eu não faço } \\
\text { nenhum trabalho para especializar o goleiro, mesmo porque tem muita criança } \\
\text { querendo jogar no gol, querendo ter essa experiência } \$ 2 ; \text { S4; S6; S12; S15. É importante } \\
\text { você pensar na questão de repertório motor, em ter outras vivências, porque quando } \\
\text { ele chegar no momento da especialização, já vai ter uma bagagem motora mais } \\
\text { ampla } \$ 4 ; \text { s5; S6; S15. Nas categorias menores, a criança tem que vivenciar o trabalho de } \\
\text { goleiro e vivenciar o trabalho da linha para observar as características de cada um } \\
\text { para então definir algumas posições, com a minha orientação enquanto treinador } \mathrm{S4} \\
\text { S5; S6; S15. }\end{array}$ \\
\hline $\begin{array}{l}\text { IC- } 22 \\
\text { Características } \\
\text { Técnicas e } \\
\text { Coordenação } \\
\text { (S4; S5; S6; S7; } \\
\text { S9; S12; S13; S15; } \\
\text { S16; S19) }\end{array}$ & 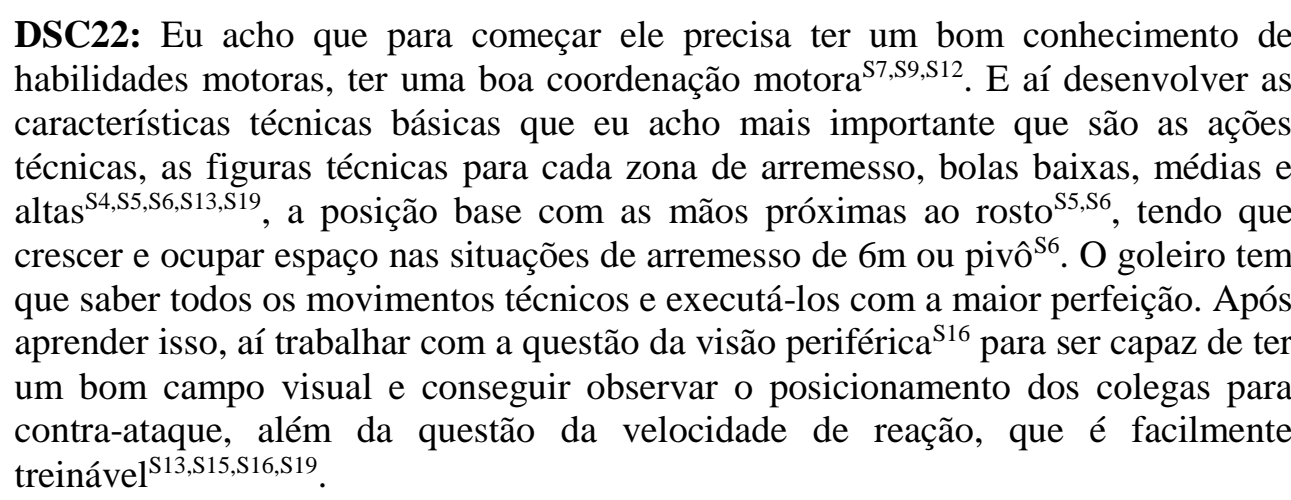 \\
\hline $\begin{array}{l}\text { IC- } \mathbf{2 3} \\
\text { Características } \\
\text { Táticas } \\
\text { (S2; S6; S7; S10; } \\
\text { S12; S13; S7; S16; } \\
\text { S17) }\end{array}$ & 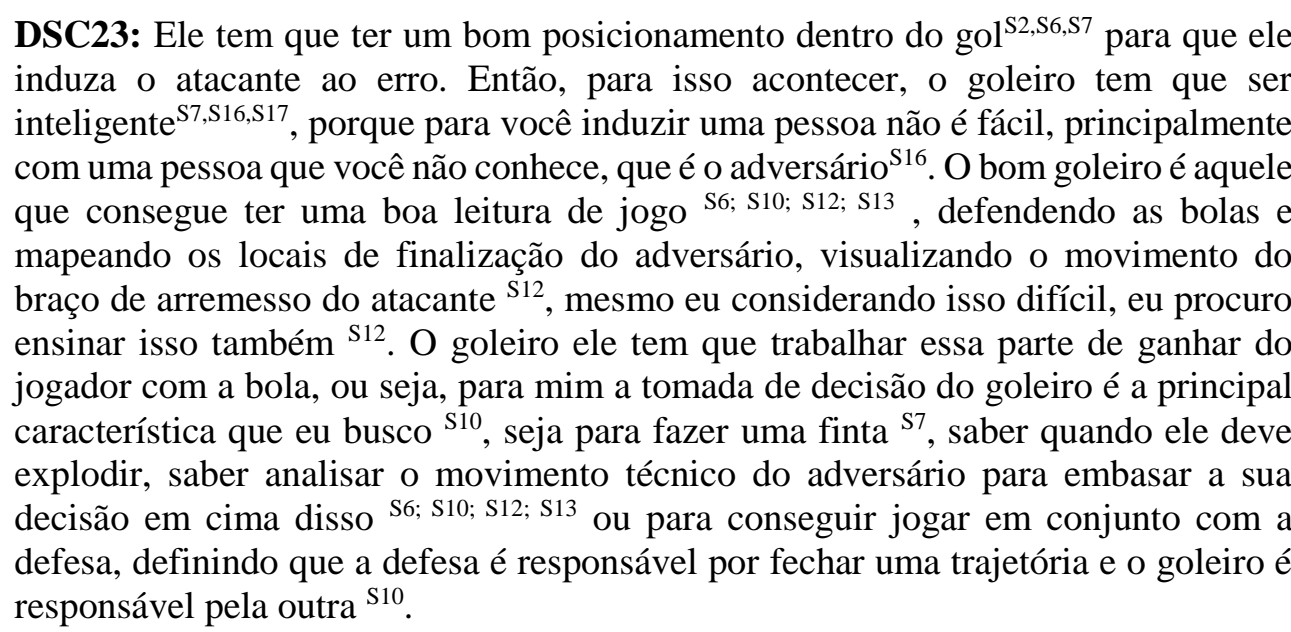 \\
\hline $\begin{array}{l}\text { IC- } 24 \\
\text { Características } \\
\text { Psicológicas } \\
(\text { S1; S3; S5; S6; } \\
\text { S7; S8; S9; S10; } \\
\text { S11; S12; S13; } \\
\text { S14; S15; S16; } \\
\text { S17) }\end{array}$ & $\begin{array}{l}\text { DSC24: Primeiro tem que ter coragem }{ }^{\mathrm{S1}, \mathrm{S5}, \mathrm{S} 6, \mathrm{~S} 8, \mathrm{~S} 9, \mathrm{~S} 11, \mathrm{~S} 12, \mathrm{~S} 15, \mathrm{~S} 16} \text {, porque a criança não } \\
\text { pode ter medo da bola, e acho que essa é uma das principais características do } \\
\text { goleiro } \mathrm{S}^{55, \mathrm{~S} 6, \mathrm{~S} 15} \text {. Mas é importante também o menino/menina querer e gostar de jogar } \\
\text { no gol, demonstrar o interesse pela posição }{ }^{\mathrm{S3}, \mathrm{S5}, \mathrm{S7}, \mathrm{S9}, \mathrm{S13}, \mathrm{S14}} \text {. A coragem é difícil de } \\
\text { passar para a criança, creio que é uma coisa que já vem com ela }{ }^{\mathrm{S} 6} \text {. Outra } \\
\text { característica importante é a concentração, e os goleiros que a gente vem formando } \\
\text { ao longo dos anos são em sua grande maioria, concentrados, equilibrados }{ }^{\mathrm{S10}} \text {. O } \\
\text { goleiro tem que ser um jogador com um pouco mais de atitude, tem que ter um } \\
\text { temperamento mais forte }{ }^{\mathrm{S} 6, \mathrm{S7}} \text {, e tem que ser esforçado }{ }^{\mathrm{S17}} \text {, porque eu não gosto de } \\
\text { goleiro que fica muito parado }{ }^{\mathrm{S} 7} \text {. }\end{array}$ \\
\hline
\end{tabular}


IC- 25

Capacidades

Motoras

(S1; S3; S6; S7;

S8; S9; S10; S11;

S12; S13; S14;

S15; S17; S18; 19)
DSC25: Dentro das características principais, temos que trabalhar bastante a

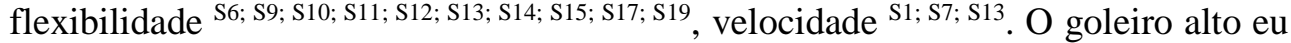
tenho que trabalhar velocidade ${ }^{\mathrm{S} 1}$. O goleiro também tem que ter agilidade ${ }^{\mathrm{S} 3 ; \mathrm{S} 8 ; \mathrm{S} 9}$; S10; S11; S13; S14 S18. Às vezes é melhor você ter um goleiro pequeno, mas que seja

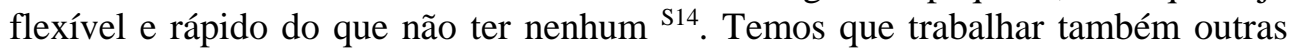
capacidades como a força e a potência muscular ${ }^{\mathrm{S} 6 ; \mathrm{S} 11 ; \mathrm{S} 12 ; \mathrm{S} 17}$.

\section{Estatura e Envergadura}

Quando se pensa na especialização de atletas, podemos considerar várias características que são baseadas na observação e/ou análise do desempenho de atletas de nível mundial. A estatura e a envergadura são características antropométricas que algumas modalidades esportivas, como o handebol, sugerem como indicadores de desempenho, como apontado pelos treinadores do DSC20. Os treinadores indicam uma preferência por goleiros altos, no entanto essa não é a realidade com que esses se deparam. Mesmo assim, admitem que é mais difícil treinar um goleiro com baixa estatura. Acredita-se que a razão por trás dessa afirmação deve-se à ideia de que os goleiros baixos não conseguiriam fechar todos os espaços do gol. Greco, Neves e Matias (2002) apontam que estatura média de um goleiro de nível mundial é de 1,95m, enquanto que a envergadura desejada é em média de 2,00m (THIENGO; VITÓRIO; FERREIRA, 2006).

Não se pode dizer que a estatura e a envergadura não são características importantes para o rendimento do goleiro de handebol. Entretanto, é preciso entender que essas não são (ou não deveriam ser) características preditoras para uma especialização no posto do goleiro de handebol. Nesse sentido, há goleiros com estaturas mais baixas que conseguem ter um nível de jogo internacional, baseando-se muito mais em sua velocidade de deslocamento, leitura de jogo e um tempo de reação muito pequeno (GRECO; NEVES; MATIAS, 2002). '

Justin et al. (2013) ao analisarem se a estatura seria um fator de bom desempenho para os goleiros de handebol eslovenos, após a realização de testes motores, perceberam que tanto os goleiros mais altos $(1,93 \mathrm{~m})$ quanto os goleiros mais baixos $(1,85 \mathrm{~m})$ obtiveram escores muito similares, não apresentando diferenças significativas. Os autores sugerem que por conta disso, se houver a possibilidade de se ter um goleiro mais alto, é algo interessante, mas salientam que, entre goleiros altos e baixos em situação de jogo, não há diferenças efetivas de 
desempenho em nenhum deles. Além disso, citam a importância de incluir no processo de formação de jogadores os aspectos relacionados com o desempenho das habilidades motoras, que são os fatores em que os goleiros mais baixos se apoiam para conseguir uma boa performance (JUSTIN et al, 2013). Com base nos achados desta pesquisa, entende-se que além das habilidades técnicas é importante o desenvolvimento das capacidades cognitivas que proporcionam uma tomada de decisão pautada na análise crítica do cenário do jogo (como abordado anteriormente pelo DSC19).

Ao contrário do que aponta o DSC20, não se deve utilizar a estatura e a envergadura como fatores de especialização do goleiro de handebol, pois não são estes os aspectos que realmente influenciam no desempenho do goleiro. Neste caso, trata-se de um conjunto de habilidades motoras relacionadas às características técnico-táticas que devem ser ensinadas aos atletas, independentemente da estatura ou da envergadura.

Considerando as aptidões individuais dos atletas, deve-se buscar uma adaptação da técnica das ações defensivas do goleiro em relação a essas características antropométricas. Loffredo e Greco (2002) categorizam dois tipos de goleiros, em relação às capacidades antropométricas: o goleiro saltador (mais baixo, que depende mais de um deslocamento mais rápido e de defesas em salto para conseguir defender bolas mais altas) e o goleiro posicionado (mais alto, que faz menos deslocamentos, procura se posicionar e fechar os espaços do gol).

Apesar das diferenças individuais, os princípios de ação do posto específico são comuns a todos os goleiros, independentemente de suas características antropométricas. Assim, não parece ser viável, escolher um atleta para o posto do goleiro pela estatura e sim pelo trabalho técnico-tático e de tomada de decisão que pode ser desenvolvido com os atletas.

Pensando na categoria sub-16, é importante lembrar que se trata de atletas no período da adolescência, e por esse motivo, estão em diferentes estágios maturacionais. Dessa forma, se há um atleta avançado maturacionalmente, que seja mais alto do que outro que ainda vai se desenvolver, a tendência é que se exclua o atleta mais baixo da possibilidade de se especializar como goleiro, ao invés de continuar desenvolvendo com ambos o entendimento do jogo e as tomadas de decisão, que são fatores que realmente influenciam no desempenho. 
Desenvolvimento do Repertório Motor, Coordenação e Características Técnicas

Outro aspecto apontado nos discursos dos treinadores sobre as características para especializar um goleiro de handebol refere-se ao desenvolvimento de um bom repertório motor nas categorias anteriores à sub-16, juntamente com um trabalho de capacidades coordenativas que irão culminar na construção das características técnicas do goleiro de handebol. Essas capacidades foram abordadas pelos treinadores no DSC21 e o DSC22.

O DSC21 descreve inicialmente que a ideia de jogar como goleiro de handebol tem que partir da vontade da criança. Seria interessante citar o aspecto da vontade do atleta quando se fala de especialização, pois quando se pensa neste processo olha-se muito mais o que os treinadores pensam do que propriamente o que o atleta pensa a respeito. No entanto, não é o que ocorre com os treinadores que compõem o DSC21, pois afirmam que escolhem os goleiros muito mais pela vontade das crianças em ter essa experiência do que por outro fator. Afinal, os treinadores podem estar imersos em uma realidade com poucos atletas para treinar, os quais iniciam tardiamente a prática do handebol (MENEZES, 2010), fazendo com que os treinadores optem por deixar os próprios atletas escolherem onde gostariam de jogar, como uma forma de estimular o gosto pela prática e evitar o seu abandono.

No entanto, menciona-se a importância de estimular a construção de um repertório motor amplo, que permita o desenvolvimento das características técnicas específicas do goleiro de handebol, como a posição base e os deslocamentos para os diferentes tipos de defesa. É neste ponto em que se aproximam o DSC21 e o DSC22, que abordam a necessidade do desenvolvimento da coordenação motora e das características técnicas.

O desenvolvimento de um repertório motor amplo a partir das vivências específicas do handebol é um aspecto inerente ao processo de iniciação e formação esportiva. Greco e Benda (2002) apontam que, mesmo com o início da prática de algum JEC, o objetivo da iniciação esportiva é deixar a criança brincar e ampliar o seu repertório motor ao mesmo tempo que vai construindo o seu conhecimento acerca do jogo, neste caso do handebol. Este cuidado deve ser tomado, para evitar que a criança entre em um processo de especialização esportiva precocemente.

Menezes, Marques e Nunomura (2014) apontam que utilizar os princípios metodológicos dos JEC de invasão, como o handebol, significa oportunizar aos atletas a construção de um repertório motor e cognitivo amplo, capaz de responder às exigências do 
jogo, adaptadas para cada faixa etária. Um destes princípios é o de promover que os atletas tenham experiências em todos os postos específicos do jogo, para vivenciar o trabalho dos jogadores de quadra e do goleiro, observando as características específicas de cada um e dessa forma, fazendo um transfer das habilidades, no momento de fato, da especialização (MENEZES, MARQUES, NUNOMURA, 2014). O trecho final do DSC21 aponta justamente para a necessidade de buscar meios e estratégias para promover um repertório motor mais amplo e aponta que a experiência dos atletas em todos os postos específicos, em conjunto com a orientação do treinador, pode ser uma boa forma de conduzir o processo de especialização do goleiro de handebol.

Para além de um repertório motor amplo, destaca-se a importância de enfatizar as capacidades coordenativas e as técnicas específicas do goleiro, como aponta o DSC22. Em relação às técnicas de defesa, vai ao encontro dos aspectos que indicou como características técnico-táticas mais importantes para o goleiro, ou seja, a posição-base, as técnicas de deslocamento para a defesa de bolas altas, médias e baixas, as defesas em saltos, os avanços e retornos do posicionamento e as fintas dos goleiros. É necessário salientar que apesar do DSC22 afirmar que o goleiro de handebol na categoria sub-16 deve ter o pleno domínio da técnica, deve-se pensar que nesta categoria, o processo de especialização vai estar apenas iniciando (SANTOS; MENEZES, 2015) e a perfeita execução dos gestos técnicos torna-se difícil de alcançar, além da necessidade de trabalhar conjuntamente os aspectos táticos e de tomada de decisão (GRECO, BENDA, 2002).

Em relação às capacidades coordenativas, o DSC22 menciona a visão periférica e a velocidade de reação. As duas capacidades mencionadas no discurso são importantes no desenvolvimento das características técnico-táticas do goleiro, uma vez que o mesmo deve ser capaz de visualizar o movimento de todo o ataque adversário e, a partir dos sinais relevantes que ele observa, preparar a sua ação defensiva de forma a estar bem posicionado e pronto para reagir rapidamente, no menor tempo possível.

Considerando a categoria sub-16, o objetivo do trabalho de coordenação motora é o de estabilização das técnicas por meio das situações de jogo real (GRECO; BENDA, 2002). É a partir desta categoria que o aprimoramento técnico passa a ter especial atenção, considerando que o atleta passou, inicialmente, por níveis de execução mais simples e foi se 
desenvolvendo até se deparar com as situações mais complexas do jogo, envolvendo a bola, os companheiros de equipe, os adversários e ele próprio (GARGANTA, 1998).

Pensar no desenvolvimento do repertório motor como base para o aprendizado e aprimoramento da técnica específica do goleiro de handebol, parece ser um fator de especialização deste posto, uma vez que há influência diretamente no desempenho, seja pela execução das técnicas de defesa ou pelo entendimento do jogo e das questões relacionadas a tática e a tomada de decisão de quando e porquê utilizar uma técnica específica.

\section{Desenvolvimento de Características Táticas}

O desenvolvimento de um repertório motor amplo na iniciação esportiva favorece a construção das técnicas específicas ao longo do processo de EAT nos JEC considerando a dimensão tática do jogo, uma vez que o jogo é essencialmente tático (GARGANTA, 1998). No handebol, e mais especificamente para o goleiro, as características táticas são fundamentais para que ele possa ter um bom desempenho diante da força e velocidade imposta nos arremessos pelos atacantes adversários (LOFFREDO; GRECO; 2002).

O DSC23 apontou o posicionamento tático do goleiro, a leitura de alguns sinais relevantes, como o braço de arremesso e as zonas de arremesso preferidas pelo adversário, a execução de fintas pelo goleiro e o trabalho colaborativo com a defesa como as características táticas importantes para especializar um atleta como goleiro de handebol na categoria sub-16. Alguns desses aspectos foram abordados no capítulo anterior, no qual os treinadores apontaram as ações mais relevantes para o goleiro de handebol de acordo com a fase de jogo e com as diferentes distâncias de arremesso.

O goleiro de handebol é um posto específico, cujo desempenho em jogo pode influenciar o desempenho e o resultado final de sua equipe. Dessa forma, o atleta deste posto deve ser capaz de compreender suas funções, sejam elas defensivas ou ofensivas, para que consiga ajudar a sua equipe. Greco (2002) aponta que o bom goleiro deve ter uma grande capacidade tática, sabendo cooperar com seus defensores e sabendo se comportar diante de diferentes sistemas de jogo. O DSC23 cita que a cooperação com os defensores é uma das características táticas importantes a se considerar na formação do goleiro, uma vez definido que a defesa é responsável por fechar um lado do gol e o goleiro o outro, esta decisão tática ajuda o 
goleiro a tomar uma decisão mais rápida e definir o seu posicionamento antes que o arremesso seja efetivamente executado, o que pode proporcionar certa vantagem.

A capacidade tática do goleiro de handebol está relacionada com a sua tomada de decisão, pois por meio da tática escolhida pelo goleiro, ele será capaz de induzir o adversário a fazer o que ele (goleiro) quer, por exemplo, quando o goleiro oferece um canto do gol de maneira proposital, mas consegue reagir rapidamente e defender a bola arremessada. Assim, o goleiro que demonstra ter um domínio de suas ações táticas, consegue se posicionar para melhor perceber os estímulos do atacante e antecipar as ações do mesmo (BENDA, XAVIER, MARTINI, 2002).

É importante salientar que as características táticas apontadas no DSC23, corroboram os discursos anteriormente apresentados neste trabalho (DSC1, DSC2, DSC4, DSC8, DSC9, DSC12 e DSC15), relacionados ao que o goleiro deve observar para fazer a sua defesa e das características técnico-táticas que suportam essas ações, como a leitura de jogo, que envolve as características do atacante, trajetórias de arremesso, locais de finalização e a colaboração com os defensores.

Antúnez Medina (2003) diz que o goleiro tem algumas intenções táticas (grifo do autor): o controle da distância do atacante com a bola; condutas de dissuasão de arremesso, que seriam as fintas; oferecer os ângulos longo e curto do gol, de maneira proposital para induzir o atacante; e as condutas de percepção e antecipação relacionadas com a tomada de decisão. Algumas dessas intenções são mencionadas no DSC16, como as condutas de dissuasão por meio das fintas, que são considerados importantes características táticas individuais do goleiro de handebol. A partir disso, entende-se que o treinamento do goleiro deve considerar os aspectos relacionados à colaboração defensiva e às diversas representações das intenções táticas do goleiro de handebol (ANTÚNEZ MEDINA, 2003).

O desenvolvimento das características táticas com o goleiro de handebol na categoria sub-16, é fundamental para que, em uma etapa inicial de especialização, o atleta possa entender e aprimorar os conceitos básicos do jogo e principalmente quais as intenções táticas do seu posto específico. Assim, concordando com o DSC23, acredita-se que as capacidades táticas, são mais um fator de especialização para o goleiro de handebol, em conjunto com os aspectos técnicos e de tomada de decisão. 


\section{Desenvolvimento de Características Psicológicas e Emocionais}

O nível de desempenho das características técnico-táticas específicas e do processo de tomada de decisão são elementos essenciais para analisar se o atleta possui um bom entendimento do jogo, no que respeita as suas fases e as funções individuais e coletivas. Além dessas características, o componente psicológico e/ou emocional é um fator que também pode influenciar no desempenho dos atletas. $\mathrm{O}$ goleiro de handebol, por estar exposto a arremessos de grande força e velocidade deve estar atento aos sinais relevantes presentes em uma situação de jogo e para isso necessita ter um perfil psicológico/emocional que permita enfrentar essas dificuldades de maneira efetiva.

O DSC24 indica a coragem, o interesse pelo jogo e pelo posto do goleiro, a concentração e o esforço para aprender como características psicológicas e/ou emocionais importantes para a formação do goleiro de handebol na categoria sub-16. No trecho inicial do DSC24 a coragem é apontada como uma das principais características psicológicas do handebol, assim como abordado por outros autores (MIRANDA; 2002; ANTÚNEZ MEDINA; 2003; THIENGO; VITÓRIO; FERREIRA; 2006). Se a cada 4 minutos, em média, o goleiro de handebol é submetido a um arremesso de grande força e velocidade (LOFFREDO; GRECO; 2002), a coragem pode ser apontada como uma característica que deve ser observada no atleta deste posto específico, principalmente em categorias menores.

Diante deste panorama de ação do goleiro, a coragem é apontada como uma característica necessária para superar o medo de que a bola atinja o rosto ou as partes íntimas podendo causar algum tipo de dor ou machucado e o medo de errar em um momento decisivo do jogo e demonstrar uma tendência em se auto-culpar pelo resultado negativo da equipe (ANTÚNEZ MEDINA, 2003) Esses são exemplos de situações que conferem medo aos goleiros de handebol, sobretudo em categorias de formação como a sub-16. O controle dessas situações de medo, ou seja, a coragem para enfrentar e superar esse tipo de situação, vai depender muito das ações do treinador com o seu atleta, pois a coragem não é algo inato, como apontado no DSC24, mas é construída ao longo do tempo por meio das experiências vividas em situações de treino e jogo que causaram algum tipo de desconforto.

Sobre este aspecto, Miranda (2002) aponta que os treinadores devem seguir algumas diretrizes para reforçar este sentimento de coragem, como valorizar o goleiro dentro da equipe, não o xingar ou menosprezá-lo em qualquer situação, auxiliá-lo a identificar as 
causas do medo e as maneiras de enfrentá-las, planejando bons treinos que desafiem e que reforcem o sentimento de sucesso do goleiro. De maneira geral, o goleiro de handebol deve reconhecer suas capacidades e entender que falhar é um aspecto que faz parte do jogo.

Outra característica apontada pelo DSC24 é a necessidade de o goleiro ser e estar concentrado durante todo o jogo. A concentração também é apontada pela literatura como uma característica psicológica importante na formação do goleiro (MIRANDA, 2002; ANTÚNEZ MEDINA, 2003; THIENGO, VITÓRIO, FERREIRA, 2006). Esta é uma característica que está intimamente relacionada com a capacidade cognitiva de atenção, de selecionar somente os estímulos importantes para tomar a decisão mais adequada mediante determinado contexto. A concentração seria, então, a capacidade de se manter atento a um determinado estímulo, pelo tempo necessário para a sua tomada de decisão, não se importando com nenhum outro sinal relevante (MIRANDA, 2002). Definir objetivos claros e orientar os goleiros quanto a estes objetivos é um bom modo de desenvolver a concentração do goleiro (MIRANDA, 2002).

A motivação para jogar e para escolher o posto específico que mais interessa (MIRANDA, 2002), aspectos apontados pelo DSC24, assim como a calma para tomar as melhores decisões em momentos de pressão (ANTÚNEZ MEDINA, 2003) são outras características psicológicas/emocionais importantes na formação do goleiro de handebol.

Não se pode negar a importância das características psicológicas na formação do goleiro de handebol, especialmente na categoria sub-16, na qual se lida com atletas dos mais diferentes contextos formativos. É possível considerar estas características no momento de especializar o goleiro de handebol, desmistificando a coragem e a concentração como capacidades inatas. A ideia aqui é que os treinadores possam proporcionar um ambiente em que os goleiros possam se sentir confiantes para desenvolver as capacidades citadas anteriormente.

\section{Desenvolvimento de Capacidades Motoras}

A última subseção deste capítulo faz referência ao desenvolvimento de algumas capacidades motoras condicionais, abordadas no DSC25, como aspectos a se considerar no momento de especializar um atleta como goleiro de handebol. Essas capacidades devem ser aliadas às capacidades técnico-tática e psicológica, pois influenciam o desempenho esportivo do goleiro de handebol da categoria sub-16. Porém, como salientado anteriormente, a influência dessas capacidades ocorre de maneira diferente quando comparado com os adultos, sendo 
necessário considerar o nível de desenvolvimento dessas capacidades nas categorias jovens como a sub-16.

Os treinadores apontaram no DSC25 que as capacidades motoras necessárias para especializar um atleta no posto do goleiro de handebol são a flexibilidade, a velocidade, a agilidade e as diferentes manifestações de força. De maneira geral, a literatura aponta as mesmas características citadas anteriormente, com o acréscimo da capacidade de resistência específica do goleiro (ZEIR; 1981; GRECO; NEVES; MATIAS; 2002; ARIAS ESTERO; 2009).

Sobre a força, Arias Estero (2009) aponta que é uma das capacidades mais complexas a se trabalhar, pois se apresenta de diversas formas durante o jogo, como deslocamentos em máxima velocidade e execução de diversos gestos técnicos sempre em máxima intensidade. Por esta razão, dentro das manifestações da força, para o goleiro de handebol é fundamental que este desenvolva um bom trabalho de potência muscular (ZEIR; 1981; ARIAS ESTERO; 2009), característica também apontada pelos treinadores no DSC25. Assim como a força, a velocidade de ação do goleiro de handebol é outra capacidade importante para o seu desempenho, por permitir que consiga executar suas ações técnico-táticas a máxima velocidade (ARIAS ESTERO, 2009).

Como a velocidade das ações de jogo no handebol vem aumentando no decorrer dos anos (ESPINA-AGULLO, 2016), conseguir responder de maneira rápida e na mesma intensidade das ações do adversário parece justificar o trabalho de velocidade com o goleiro de handebol. Em conjunto com o trabalho de força e velocidade, o DSC25 aponta a necessidade de o goleiro de handebol ser ágil, ou seja, conseguir mudar a direção de um deslocamento defensivo ou mesmo ser capaz de, rapidamente, retificar a sua ação de defesa devido a um desvio da bola em algum defensor.

Contudo, de nada irá adiantar o goleiro ser rápido, ágil, com grande potência muscular, se não conseguir ter amplitude de movimento para executar suas ações técnico-táticas de maneira correta. Assim, o trabalho de flexibilidade é apontado também como um dos mais importantes a se desenvolver com o goleiro de handebol (CHAGAS; 2002; ARIAS ESTERO; 2009), pelo fato de influenciar no modo como o goleiro executa o gesto técnico, afetando a eficácia e a fluidez do movimento, podendo torná-lo menos dispendioso, do ponto de vista energético (ARIAS ESTERO; 2009). 
Em dois trechos do DSC25 há a menção de uma suposta relação entre a estatura dos goleiros e as capacidades físicas que devem ser mais trabalhadas, sendo para o goleiro alto a velocidade e para o goleiro baixo a flexibilidade. Não se pode negar a diferença de estatura de um goleiro e as possíveis adaptações técnico-táticas a serem feitas para que o mesmo consiga um bom desempenho em jogo. Contudo, deve ser realizado um trabalho de flexibilidade e velocidade com os goleiros, independentemente da estatura, assim como de resistência específica e força (LOFFREDO, GRECO, 2002; ANTÚNEZ MEDINA, 2003; ARIAS ESTERO, 2009), o que contrapõe a opinião dos treinadores do DSC25.

Na categoria sub-16, assim como as demais características citadas, é preciso enfatizar as capacidades motoras que influenciam o desempenho esportivo. Por ser o momento de início da fase de especialização do goleiro de handebol, pode-se realizar alguns trabalhos específicos de cada uma das capacidades citadas no DSC25. No entanto, é preciso ter o cuidado de entender a fase em questão e a faixa etária envolvida, de forma a adequar os princípios de intensidade e volume para o treinamento destas capacidades, respeitando as questões maturacionais.

O objetivo deste capítulo foi apresentar as características técnico-táticas que suportam as ações de defesa do goleiro de handebol e as características necessárias para a especialização deste posto específico, apontadas pelos treinadores entrevistados da categoria sub-16 (Figura 8).

Os DSC apresentaram uma relação muito próxima com as ações de defesa do goleiro apontadas no Capítulo 3, indicando que as características apontadas realmente servem de base para as ações citadas anteriormente. Em relação à especialização do goleiro, destaca-se a preocupação com o desenvolvimento técnico e com a tomada de decisão eficaz, pautada em um goleiro que não tenha medo da bola e que consiga realizar suas ações defesa de forma rápida, independentemente da sua estatura e envergadura. 
Figura 8. Características do processo de formação do goleiro de handebol na categoria sub-16

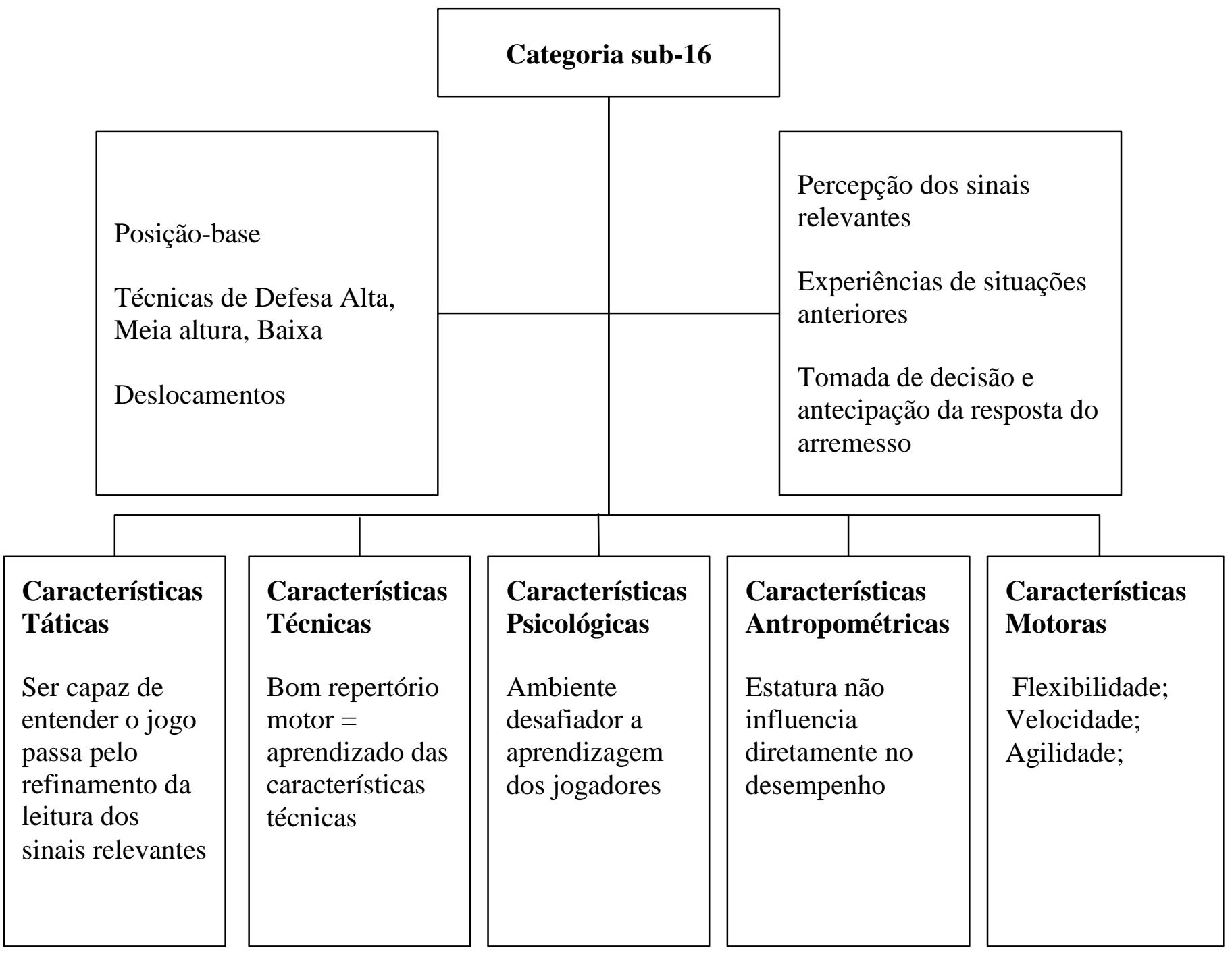




\section{CONSIDERAÇÕES FINAIS}

O goleiro de handebol é um posto específico complexo, cujo desempenho é influenciado diretamente por variáveis de características distintas. Essa complexidade inerente a esse posto específico é iminente quando se discute a atuação de goleiros em categorias jovens, como é o caso da categoria sub-16. Nessa, o treinamento deve ser sistematizado de forma diferente da categoria adulta, respeitando as características próprias dessa fase do processo de EAT, em especial, por ser permeada pelas vivências anteriores e pelos aspectos maturacionais.

A partir dos achados da revisão sistemática apresentada neste trabalho (Capítulo 1), percebe-se que há ainda uma lacuna em relação aos estudos com goleiros jovens especialmente considerando a análise de jogo e o processo de EAT. Diante do panorama apresentado, fez-se importante discutir a formação dos goleiros de handebol nas categorias jovens para evitar uma reprodução das características e dos métodos de treino empregados na categoria adulta. Assim, a categoria sub-16 foi escolhida por ser considerada a fase em que se inicia o processo de especialização do goleiro de handebol, pensando em uma formação em longo prazo. A opção por entrevistar os treinadores dessa categoria, considerou as experiências vivenciadas por esses como mediadores do processo de EAT, assim seus discursos são influenciados diretamente pelas suas concepções e o seu entendimento sobre o handebol e o posto do goleiro.

A partir dos resultados, a estrutura da discussão apresentou um encadeamento de ideias que permitiu contemplar o objetivo geral deste trabalho, que foi identificar as diretrizes para a formação esportiva do goleiro de handebol baseado na opinião dos treinadores da categoria sub-16. A partir da elaboração dos discursos referentes aos sinais relevantes em diferentes fases de jogo e diante de arremessos de diferentes distâncias, foi possível estabelecer interessantes relações com as características técnico-táticas que suportam as ações identificadas e as características necessárias para especializar o goleiro de handebol na categoria sub-16.

Em um primeiro momento procurou-se estabelecer, de maneira geral, as ações e sinais mais importantes que o goleiro deve identificar de acordo com o ataque adversário e a partir do ataque da própria equipe. Em relação a fase defensiva, foram observados quatro sinais: a posição do braço de arremesso do atacante, a identificação do padrão de arremessos e das características dos atacantes, as trajetórias pré-arremesso e o trabalho colaborativo do goleiro com os seus defensores. Já em relação à fase ofensiva o goleiro deve ser capaz de entender o 
modelo de jogo de sua equipe, para oferecer determinadas orientações técnico-táticas para os jogadores de quadra, auxiliando no desenvolvimento do ataque de sua equipe. Outro aspecto apontado foi a participação do goleiro no momento de reposição da bola em jogo, no qual este deve tentar repor a bola rapidamente procurando por vantagens durante a transição ofensiva, como contra-atacar em superioridade numérica ou fazer com que sua equipe possa atacar sem que a defesa adversária (mesmo em igualdade numérica) possa se organizar.

Em um segundo momento, buscou-se especificar as ações de defesa do goleiro de acordo com as diferentes distâncias de arremessos, considerando os arremessos de longa distância (9m), de curta distância $(6 \mathrm{~m})$ e as cobranças de $7 \mathrm{~m}$. Para os arremessos de 9m, o goleiro deve ter uma boa leitura dos sinais relevantes, buscando perceber os momentos que o atacante realmente tem intenção de arremessar, para preparar o seu posicionamento no gol, sendo responsável por proteger um lado, enquanto os defensores devem proteger o outro. Já para os arremessos de $6 \mathrm{~m}$, além da leitura, o goleiro deve preocupar-se em diminuir os espaços de arremesso do atacante, buscando avançar o seu posicionamento (ganhar profundidade) momentos antes do arremesso, evitando uma possível retificação do atacante. Para uma cobrança de $7 \mathrm{~m}$, a efetividade do goleiro vai depender de como esse consegue identificar as características técnico-táticas do atacante e como define o seu posicionamento, se mais ou menos adiantado em função da estatura ou da forma como é feita a cobrança dos $7 \mathrm{~m}$.

Alguns dos sinais e das ações apontadas especialmente nos DSC8, DSC9, DSC12 e DSC17, eram comuns em mais de uma das distâncias de arremesso, guardada a devida especificidade. Assim, percebeu-se que a capacidade de leitura do goleiro em identificar o braço de arremesso e as características técnicas do atacante são aspectos importantes em todas as distâncias. Nos arremessos de $9 \mathrm{~m}$ e $6 \mathrm{~m}$ há maior proximidade em relação aos sinais relevantes, devido às trajetórias dos atacantes no momento da finalização e da colaboração entre goleiro e defensores para induzir o atacante a arremessar em uma zona do gol que facilite o posicionamento do goleiro. Além disso, as capacidades de percepção e antecipação (nomeadas como leitura do goleiro no DSC8) também foram apontadas nos achados da revisão sistemática, em específico a identificação das características dos atacantes nas cobranças de $7 \mathrm{~m}$.

Diante das características apontadas, percebe-se uma concepção do posto do goleiro baseado em ações que dependem do seu entendimento sobre o jogo, o que deveria evitar a execução de ações estereotipadas sem sentido, aspecto também salientado tanto pelo DSC 
quando pela revisão sistemática. Esses achados demonstram a necessidade de pautar o processo de EAT em aspectos que transcendam o domínio de um conjunto de técnicas consideradas relevantes para o seu posto.

Com a identificação das ações do goleiro de handebol em jogo, buscou-se entender quais são as características técnico-táticas importantes para dar suporte ao desenvolvimento dessas ações em jogo. Foram elaborados dois DSC: o primeiro que mencionava as características essencialmente técnicas, como a posição-base do goleiro de handebol e as ações de deslocamento para a defesa de bolas altas, meia altura e baixas entre outras técnicas de defesa, como a defesa em "X" e o espacato. O segundo se referia às capacidades envolvidas no processo de tomada de decisão. Percebeu-se que os treinadores valorizam esta capacidade em seus goleiros, pois consideram que o goleiro deve compreender o jogo para conseguir ser capaz de ler o que está acontecendo e tomar decisão a partir do contexto que está se desenhando.

A partir dos DSC, verificou-se uma aproximação do que pensam os treinadores sobre a formação do goleiro de handebol com diferentes autores, principalmente por entenderem que na categoria sub-16 deve se enfatizar as capacidades de percepção e antecipação, além das características técnicas específicas. Sobretudo, os achados da revisão sistemática corroboram a opinião dos treinadores nesse quesito, uma vez que a maior precisão das ações e o menor tempo para reagir mediante diferentes situações propostas pelo jogo vão depender do desenvolvimento do repertório motor e técnico associados às capacidades cognitivas.

A partir da identificação das ações do goleiro em situação de jogo e das características técnico-táticas que subsidiam essas ações, buscou-se identificar, então, as características necessárias para especializar o goleiro de handebol. Foram apontadas as seguintes características: a estatura e a envergadura, o repertório motor, as capacidades técnicas, as capacidades táticas, as capacidades psicológicas e as capacidades motoras.

Conclui-se que o repertório motor em conjunto com as capacidades técnicas e táticas relacionadas com a tomada de decisão, são importantes balizadores para especializar o goleiro de handebol, mas necessitam de um planejamento para o desenvolvimento em longo prazo, iniciando-se em categorias anteriores à sub-16. Sobre as capacidades psicológicas, percebeu-se que o treinador é responsável pela criação de um ambiente desafiador e que desenvolva confiança ao futuro goleiro, de forma que este aprenda a lidar com as situações de 
medo da bola e das falhas em situação de jogo. Em relação às capacidades motoras, foram apontadas como importantes as capacidades de flexibilidade, velocidade, agilidade e potência muscular.

As capacidades antropométricas citadas (estatura e envergadura) não foram consideradas para a especialização do goleiro de handebol, pois não influenciam diretamente no seu desempenho, diferentemente do que pensam os treinadores. Essas capacidades podem influenciar o aprendizado das técnicas específicas e da tomada de decisão, porém não se pode afirmar que um goleiro é melhor que o outro pela estatura. Assim, não cabe apontar aqui que não se pode selecionar os goleiros mais altos, mas que essa escolha não deve ser pautada exclusivamente pela estatura, mas pelo conjunto de capacidades requeridas para esse posto.

Diante do panorama apresentado sobre as ações e as características que permeiam o processo de EAT do goleiro de handebol na categoria sub-16, considera-se que a formação do goleiro de handebol deve se pautar no desenvolvimento de um amplo repertório motor associado com a tomada de decisão em situações de jogo, que permita ao goleiro identificar os principais sinais relevantes decorrentes das ações dos atacantes para se posicionar de maneira que facilite a sua decisão por uma ação que consiga responder de forma rápida e eficaz ao problema apresentado pela situação de jogo.

Esta pesquisa contribui ao identificar diretrizes específicas para o processo de EAT do goleiro de handebol, particularmente na categoria sub-16. Outro aspecto importante, é o fato desta pesquisa ter buscado a opinião dos treinadores para estabelecer essas diretrizes, uma vez que estes são os principais responsáveis por mediar este processo. Dessa forma, os achados podem contribuir diretamente com o trabalho prático de treinadores, especialmente de categorias jovens, ao servir como referência para que esses procurem desenvolver um processo de EAT em longo prazo, considerando as características individuais dos jogadores e as particularidades do seu contexto de atuação em cada categoria. Assim, espera-se que esta pesquisa possa ajudar a preencher a lacuna de estudos com goleiros de handebol das categorias jovens e vir a ser um material bibliográfico importante para a área de Educação Física, em específico para a sub-área da Pedagogia do Esporte e do Handebol. 


\section{REFERÊNCIAS BIBLIOGRÁFICAS}

ANTÚNEZ MEDINA, A. LA INTERCEPTACIÓN EN LA PORTERA DE BALONMANO: EFECTOS DE UN PROGRAMA DE ENTRENAMIENTO PERCEPTIVOMOTRIZ, 2003. 360 f. Tese (Doutorado) -, Universidad de Murcia, Murcia, Espanha, 2003.

ANTÚNEZ MEDINA, A. et al. Estudio piloto del efecto de un programa de entrenamiento perceptivo-motor sobre la eficacia en competición de la portera de balonmano según la situación del lanzador. Retos: Nuevas tendencias en Educación Física, Deporte y Recreación, Madrid, Espanha, v. 18, p.29-34, set. 2010. Disponível em: <http://www.redalyc.org/articulo.oa?id=345732284006>. Acesso em: 8 dez. 2016.

ARIAS ESTERO, J.L. El Portero de Balonmano. Revista Internacional de Deportes Coletivos, Madrid, v.4, p.14-34, 2009.

BAYER, C. O ensino dos desportos colectivos. Lisboa, Dinalivro, 1994.

BENDA, R.N.; XAVIER, A. J. M.; MARTINI, C. O. P.; Treinamento de Velocidade: um bom goleiro reage rapidamente. In: GRECO, P.J. (Org.) Caderno do Goleiro de Handebol. Belo Horizonte: Editora Philippka Verlag Minster, 2002. Cap. 15, p. 177-186.

CASTRO D'ÁVILA, R. et al.; Modelos de Avaliação do Comportamento Técnico-Tático do Goleiro de Handebol In: GRECO, P.J. (Org.) Caderno do Goleiro de Handebol. Belo Horizonte: Editora Philippka Verlag Minster, 2002. Cap. 22, p. 235-254.

CHAGAS, M. H.; Teoria do Treinamento da Flexibilidade (não só) para o Goleiro de Handebol In: GRECO, P.J. (Org.) Caderno do Goleiro de Handebol. Belo Horizonte: Editora Philippka Verlag Minster, 2002. Cap. 10, p. 113-122.

ESPINA-AGULLÓ, J. J. et al. Effectiveness of Male Handball Goalkeepers: A historical overview 1982-2012. International Journal Of Performance Analysis In Sport. Alicante, Espanha, p. 143-156. abr. 2016. Disponível em: <https://www.researchgate.net/publication/299413170_Effectiveness_of_Male_Handball_Go alkeepers_A_historical_overview_1982-2012>. Acesso em: 08 dez. 2016.

FISCHER, G. et al.; La Escuela de Porteros en Balonmano. In: Real Federación Española de Balonmano (Org.). ESTUDIO MONOGRAFICO EL PORTERO DE BALONMANO. Madrid: da, 1992. Cap. 4. p. 2-92.

FLICK, U. Introdução à Pesquisa Qualitativa. Artmed Editora S.A. 2009. 405 ISBN 978-85363-1711-3.

GARGANTA, J. Para uma teoria dos jogos desportivos colectivos. In: Graça A, Oliveira J. (Ed.) O Ensino dos Jogos Desportivos. Porto: Faculdade de Ciências do Desporto e de Educação Física. Porto: Centro de Estudos dos Jogos Desportivos, 1998. 
GRECO, P.J. La formación de jugadores inteligentes. Revista de Educación Física y Deportiva Stadium, Argentina, v. 22, p.22-30, 1988.

GRECO, P.J. (Org.) Caderno do Goleiro de Handebol. Belo Horizonte: Editora Philippka Verlag Minster, 2002.

GRECO, P.J.; BENDA, R.N. O Sistema de Formação e Treinamento Esportivo do Goleiro de Handebol. In: GRECO, P.J. (Org.) Caderno do Goleiro de Handebol. Belo Horizonte: Editora Philippka Verlag Minster, 2002. Cap. 2, p. 21-32.

GRECO, P. J.; FERREIRA FILHO, E.; OLIVEIRA JUNIOR, T. F.; Programa de Treinamento: Iniciação do Contra-Ataque. In: GRECO, P.J. (Org.) Caderno do Goleiro de Handebol. Belo Horizonte: Editora Philippka Verlag Minster, 2002. Cap. 21, p. 229-234.

GRECO, P.J.; NEVES, L.A.R.S. das; MATIAS, C. J. A.S. Evolução Técnico-Tática do Rendimento do Goleiro de Handebol. In: GRECO, P. J. (Org.). Caderno do Goleiro de Handebol. 2. ed. Belo Horizonte: Editora Philippka Verlag Minster, 2002. Cap. 5. p. 53-70.

HELM, F.; REISER, M.; MUNZERT, J.. Domain-Specific and Unspecific Reaction Times in Experienced Team Handball Goalkeepers and Novices. Frontiers In Psychology, v. 7, p.1-11, 21 jun. 2016

JUSTIN, I. et al. ARE TALLER HANDBALL GOALKEEPERS BETTER?: CERTAIN CHARACTERISTICS AND ABILITIES OF SLOVENIAN MALE ATHLETES. Kinesiology, Bled, Slovenia, v. [], n. 45, p.252-261, nov. 2013.

LEFEVRE, F.; LEFEVRE, A. M.; Pesquisa de Representação Social: Um Enfoque Qualiquantitativo. Brasília: Liber Livro Editora Ltda., 2012. 224 p.

LOFFREDO, M.; GRECO, P. J. Capacidade Técnica: Posições Básicas de Defesa da Bola. In: GRECO, Pablo Juan. (Org.) Caderno do Goleiro de Handebol. Belo Horizonte: Editora Philippka Verlag Minster, 2002. Cap. 3, p. 33-46.

MANZINI, E.J. Uso da entrevista em dissertações e teses produzidas em um programa de pósgraduação em educação. Revista Percurso, Maringá, v.4, n.2, p.149-171, 2012.

MARCONI, M. A.; LAKATOS, E. M.; Fundamentos de Metodologia Científica. 5. ed. São Paulo: Atlas S.a., 2003. 310 p.

MATIAS, C.J.; GRECO, P.J. Cognição \& ação nos jogos esportivos coletivos. Ciências e Cognição, Rio de Janeiro, v.15, n.1, p.252-271, 2010.

MENEZES, R.P.; REIS, H.H.B. Análise do jogo de handebol como ferramenta para sua compreensão técnico-tática. Motriz, v.16, n.2, p.458-467, 2010. 
MENEZES, R. P.. O ENSINO DOS SISTEMAS DEFENSIVOS DO HANDEBOL: CONSIDERAÇÕES METODOLÓGICAS ACERCA DA CATEGORIA CADETE. Pensar A Prática, Goiânia, v. 13, n. 1, p.1-15, 2010.

MENEZES, Rafael Pombo. Modelo de análise técnico-tática do jogo de handebol: necessidades, perspectivas e implicações de um modelo de interpretação das situações de jogo em tempo real. 2011. 303f. Tese (Doutorado em Educação Física)-Faculdade de Educação Física. Universidade Estadual de Campinas, Campinas, 2011.

MENEZES, R. P.; MARQUES, R. F. R.; NUNOMURA, M.. Especialização esportiva precoce e o ensino dos jogos coletivos de invasão. Movimento, Porto Alegre, v. 20, n. 1, p.351-373, mar. 2014.

MENEZES, R.P.; REIS, H.H.B.; TOURINHO FILHO, H. Ensino-aprendizagem-treinamento dos elementos técnico-táticos defensivos individuais do handebol nas categorias infantil, cadete e juvenil. Movimento, v.21, n.1, p.261-273, 2015.

MIRANDA, R.; O Medo, a Coragem e a Motivação no Treinamento do Goleiro de Handebol In: GRECO, P.J. (Org.) Caderno do Goleiro de Handebol. Belo Horizonte: Editora Philippka Verlag Minster, 2002. Cap. 16, p.187-202.

OLIVER CORONADO, J.F.; SOSA GONZÁLES, P.I. Balonmano: la actividad física y deportiva extraescolar en los centros educativos. Barcelona: Ministerio de Educación y Cultura, 1996, apud MENEZES, R.P.; REIS, H.H.B. dos. Análise do jogo de handebol como ferramenta para sua compreensão técnico-tática. Motriz, v.16, n.2, p.458-467, 2010.

PASCUAL FUERTES, X. PEÑA BARCELÓ, R; El portero de balonmano:: una aplicación práctica de entrenamiento perceptivo-decisional ante lanzamientos de primera línea. Apunts: Educación Física e Esports, Catalunya, Espanha, v. 84, p.66-75, set. 2006. Disponível em: http://www.raco.cat/index.php/ApuntsEFD/article/viewFile/300831/390278. Acesso em: 8 dez. 2016.

PASCUAL FUERTES, X. El entrenamiento del portero de balonmano:: propuesta práctica sobre el desarrollo de la metodología basada en el tiempo. Revista Entrenadores Rfebm, Madrid, Espanha, n. 250, p.8-16, fev. 2007. Disponível em: <http://www.rfebm.com/rev_entrenadores28.pdf>. Acesso em: 8 dez. 2016.

PASCUAL FUERTES, X; LAGO PEÑAS, C.; CASÁIS MARTINEZ, L.; La influencia de la eficacia del portero en el rendimiento de los equipos de balonmano. Apunts: Educación Física y Deportes, Catalunya, Espanha, n. 99, p.72-81, fev. 2010. Disponível em: <http://www.revista-apunts.com/es/hemeroteca?article=1411>. Acesso em: 8 dez. 2016.

PRUDENTE, J.; GARGANTA, J.; ANGUERA, M.T. Desenho e validação de um sistema de observação no andebol. Revista Portuguesa de Ciências do Desporto, v.4, n.3, p.49-65, 2004. 
RAMARI, C.F. Análise técnico-tática de handebol de equipes da categoria cadete. 2008. 85f. Trabalho de Conclusão de Curso (Graduação) -Faculdade de Educação Física. Universidade Estadual de Campinas, Campinas, 2008.

SÁ, P.; FERNANDÉZ ROMERO, J.; GOMES, A.R. A tomada de decisão no guarda-redes de andebol. In: CONFERÊNCIA INTERNACIONAL DE PSICOLOGIA DO DESPORTO \& EXERCÍCIO, 2007, Universidade do Minho, Braga, Portugal. Actas da Conferência Internacional de Psicologia do Desporto e Exercício. Braga: Cipde'07, 2007. p. 60 - 75. Disponível em: <http:// repositorium.sdum.uminho.pt/bitstream/1822/7937/1/3ActasConfer\%C3\%AAncia-PDE-Tomada\%20decis\%C3\%A3o.pdf >. Acesso em: 22 out. 2014.

SÁ, P. et al. Percepción de los porteros expertos en balonmano de los factores determinantes para el éxito deportivo. Revista de Psicología del Deporte, v.24, n.1, p.21-27, 2015.

SANTOS, W. R.; MENEZES, R. P.. OS MOTIVOS PARA A ESPECIALIZAÇÃO DOS GOLEIROS DE HANDEBOL A PARTIR DOS DISCURSOS DE TREINADORES.. Resumos do IX Congresso Internacional de Educação Física e Motricidade Humana XV Simpósio Paulista de Educação Física (VIII CIEFMH e XIV SPEF). Rio Claro: Motriz, 2015. v. 21, p. 238 - 239.

SCAGLIA, A. et al. O ensino dos jogos esportivos coletivos: as competências essenciais e a lógica do jogo em meio ao processo organizacional sistêmico. Movimento, Porto Alegre, v. 19, n. 4, p.227-249, 2013.

SILVEIRA, D.T.; CÓRDOVA, F.P. A pesquisa científica. In: GERHARDT, T.E.; SILVEIRA, D.T. (Org.). Métodos de Pesquisa. Porto Alegre: Editora da UFRGS, 2009. Cap. 2. p. 31-42.

SINGER, E.; El Portero de Balonmano. In: Real Federación Española de Balonmano (Org.). ESTUdiO MONOGRAFICO EL PORTERO DE BALONMANO. Madrid: da, 1992. Cap. 2. p. 1-89.

THOMAS, J. R.; NELSON, J. K.; SILVERMAN, S. J.. Métodos de Pesquisa em Atividade Física. 6. ed. Porto Alegre: Artmed, 2012. 478 p.

THIENGO, C.R.; VITÓRIO, R.; FERREIRA, L.A. O goleiro de Handebol. Efdeportes.com Revista Digital, Buenos Aires, v.11, n.100, 2006.

TRIVIÑOS, A.N.S. Introdução à pesquisa em ciências sociais: a pesquisa qualitativa em educação. São Paulo: Atlas, $1^{a}$ edição, 1987.

WAGNER, H. et al. Individual and Team Performance in Team-Handball: A Review. Journal Of Sports Science And Medicine. Salzburg, p. 808-816. Dez. 2014.

ZEIR, U.; El Portero de Balonmano. In: Real Federación Española de Balonmano (Org.). ESTUdiO MONOGRAFICO EL PORTERO DE BALONMANO. Madrid: da, 1992. Cap. 3. p. 2-46. 
ANEXOS

ANEXO A - Termo de Consentimento Livre e Esclarecido

\author{
TERMO DE CONSENTIMENTO LIVRE E ESCLARECIDO (TCLE)
}

O(A) Sr(a) foi selecionado(a) e está sendo convidado(a) para participar da pesquísa intitulada "O discurso dos treinadores esportivos: aspoctos relevantes para a formaçäo de jogadores", que tem como objetivos, identificar os contećdos mais relevantes para as categorias de formaçho no esporte, bem como os métodos de ensino utilizados. Este estudo tem como método de coleta de dados a aplicaç̄ó de entrevistas com os treinadores esportivos que dirigem atualmente equipes que disputam ligas esportivas no Estado de Săo Paulo. Esta pesquisa serà desenvolvida na Escola de Educaçāo Fisica e Esporte de Ribeirāo Preto, sob responsabilidade do pesquisador Prof. Dr. Rafael Pombo Menezes.

Suas respostas serảo tratadas de forna anônima e confidencial, isto ê, em nenhum momento será divulgado o seu nome em qualquer fase do estudo. Quando for necessário exemplificar determinada situasso, sua privacidade será assegurada uma vez que seu nome näo aparecerá en qualquer monento. $\mathrm{Os}_{s}$ dados coletados, após leitura e aprovaçấo de sua parte, serảo utilizados apenas nesta pesquisa e os reseltados divulgados em eventos e/ou revistas cientificas.

Sua participaçî́ è voluntária, isto è, a qualquer momento vook pode recusar-se a responder qualquer pergunta ou desistir de participar e retirar seu consentimento. Sua recusa não trará nenhum prejuizo em sua relaça com os jogadores e com o clube elou equipe comandada.

Sua participaçâo nesta pesquisa consistirá em responder a entrevista, que serà gravada em áudio para posteriơ análise, visto que isso possibilita a preservaçào dos dados e investigaçẩo sobre os temas tratados. Após a utilizaçăo do áudio e transtriçāo das entrevistas, os arquivos serilo guardados por 5 anos e após este período serão descartados. O tempo esperado para a entrevista é de 80 a 100 minutos e será aplicado pelos pesquisadores responsiveis em local e data escolhidos pelo(a) $\operatorname{Sr}(a)$.

O(A) Sr(a). não terá nenhum casto ou quaisquer compensaçóes financeiras. Esta pesquisa apresenta como risco acessar sentimentos do sujeito durante a entrevista, podendo causar algum tipo de emoç̄̄o negativa. Caso haja slguma intercorrtocia o pesquisador providenciará todo o suporte necessario. Diante de eventuais danos decorrentes da pesquisa será garantida indenizaciso conforme as Leis vigentes no pais. O beneficio relacionado à sua participaçũo será de ampliar os horizontes de conhecimento cientifioo para a área de Educaçà Fissica e Esporte, em especifico para o handebol nacional.

$O(A) \operatorname{Sr}(a)$, receberá uma vis deste termo onde consta o telefone/e-mail dos pesquisadores responsáveis, podendo tirar as suas dúvidas sobre o projeto e sua participaçăo, agora ou a qualquer momento. Desde já agradeço!

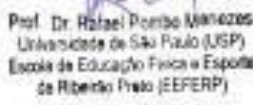

Pesquisador respossável: Prof. Dr. Rafael Pombo Menezes. E-mail: rafaelpombo@ @usp.br Escola de Educaçăo Física e Esporte de Ribeirăo Preto (EEFERP), Universidade de Săo Paulo (USP). Avenida Bandeirantes, 3900 - Monte Alegre. Ribeirăo Preta/SP. Contsto: (16) 3315-0349.

Declaro estat ciente do inteiro teor deste TERMO DE CONSENTIMENTO, e que minhas respostas a entrevista serdo gravadas em áudio e estou de acordo em participar do estudo proposto sob tais condigbes, sabendo que dele poderei desistir a qualquer momento, sem sofrer qualquer prejuizo ou constrangimento e que receberei uma copia do termo de consentimento livre esclarecido, sendo que essa ficará em minha posse. Para notificaçầo de qualquer situaçâo relacionada com a ética que não pudet ser resolvida pelos pesquisadores deverei entrar em contato com o Comitê de Êtica em Pesquisa da Escola de Educação Física e Esporte de Ribeirão Preto, Avenida dos Bandeirantes, 3900 - Bloco 3 - Sala I6 - 14040-907 - Ribeirẫo Preto - SP, fone (16) 3315-0494, e-mail: cep90@usp,br. 
ANEXO B - Parecer do Comitê de Ética

Declaramos que a EMENDA ao trabalho intitulado "O discurso de treinadores de Handebal do Estado de São Paulo sobre processos de ensinoaprendizagem-treinamento em diferentes categarias', CAAE: 39796814.8.0000.5659, do pesquisador Prof. Dr. Rafael Pombo Menezes, para a inclusão de outras modalidades esportivas, foi APROVADO pelo Comitẻ de Ética em Pesquisa da Escola de Educaçẵo Fisica e Esporte de Ribeirăo, em sua $6^{a}$ reunião do dia 23/02/2015.

Ribeiråo Preto, 05 de dezembro de 2016.

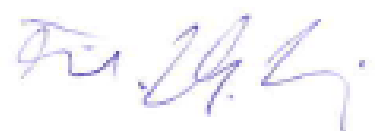

Prof. Dr. Cristiano Roque Antunes Barreira Vice-Coordenador do CEP/EEFERP 


\section{APÊNDICES}

APÊNDICE A - Transcrição das respostas do bloco de "Dados Pessoais" do instrumento de entrevista semiestruturado

\begin{tabular}{|c|c|}
\hline \multicolumn{2}{|c|}{ 1. Qual a sua idade? } \\
\hline Sujeito & Idade \\
\hline S1 & 54 \\
\hline S2 & 43 \\
\hline S3 & 32 \\
\hline S4 & 35 \\
\hline S5 & 45 \\
\hline S6 & 48 \\
\hline S7 & 31 \\
\hline S8 & 43 \\
\hline S9 & 55 \\
\hline S10 & 34 \\
\hline S11 & 34 \\
\hline S12 & 37 \\
\hline S13 & 44 \\
\hline S14 & 44 \\
\hline S15 & 48 \\
\hline S16 & 53 \\
\hline S17 & 36 \\
\hline S18 & 30 \\
\hline S19 & 30 \\
\hline Média & 40,84 \\
\hline DP & 8,32 \\
\hline MAX & 55 \\
\hline MIN & 30 \\
\hline
\end{tabular}

2./ 3. Possui curso de Graduação? Em qual área? Em que ano? Onde? Possui curso de Pós-Graduação? Em qual área? Em que ano? Onde?

SIM - Graduação

S1 - Educação Física

S2 - Educação Física; 1992, Unimep, Piracicaba

S3 - Educação Física . 2011, UNOPAR, Londrina 
S4 - cursando Educação Física, porque eu cheguei a fazer 4 anos de pleno (licenciatura plena) e ai mudou-se a grade e agora eu faço adaptações; ESEF , Jundiaí

S5 - Licenciatura Plena, Educação Física, 1994, USP , São Paulo

S6 - Educação Física, 1992, Faculdades Integradas de Guarulhos

S7 - Licenciatura, 2008; Bacharelado, 2012, Unicamp - Campinas

S8 - Educação Física, 1998, Santos

S9 - Educação Física, 1984, FEFISA, Santo André

S10 - Licenciatura e Bacharel em Educação Física; 2003,Universidade Cruzeiro do Sul, São Paulo

S11 - Licenciatura Plena Educação Física, FMU, 2004, São Paulo

S12 - Licenciatura e Bacharelado em Educação Física, 2009, Faculdades Metrocamp, Campinas

S13 - Educação Física, 1995, Unesp, Rio Claro

S14 - Educação Física, 2006, Unimep, Piracicaba

S15 - Educação Física,1988, ESEF, Jundiaí,

S16 - Educação Física, 1984, FEFISA, Santo André

S17 - Licenciatura e Bacharelado, 2003, Mogi-Náutico, Mogi das Cruzes

S18 - Educação Física, 2010, Unip, Jacareí

S19 - Educação Física, 2007, Unitau, Taubaté

\section{SIM - Pós-Graduação}

S2 - Pós-graduação em Handebol; 2016; Faculdades Ipanema, Sorocaba

S5 - Especialização em Handebol; 2000/2001; USP , São Paulo

S6 - Pós-Graduação em Handebol, 2013, ESEF , Jundiaí

S7 - Especialização em Handebol, 2012 , ESEF, Jundiaí/ Mestrado - Saúde Óssea do Adolescente Atleta (Handebol e Natação) / Doutorado (em curso) - Saúde Óssea do Adolescente Atleta (Handebol), Unicamp, Campinas

S9 - Especialização em Técnico de Handebol, 1994, FEFISA, Santo André

S10 - Especialização em Jogos Pré-Desportivos, Universidade São Judas Tadeu.

S12 - Pós-Graduação em Fisiologia do Exercício, 2012, Faculdades Metrocamp, Campinas

S13 - Especialização em Handebol, 2010 , ESEF, Jundiaí

S16 - Especialização em Handebol, 2016, FEFISA, Santo André 
S19 - Especialização em Atividade Motora Adaptada, Unicamp, 2009, Campinas / Especialização em Handebol, 2010 , ESEF, Jundiaí

\author{
NÃO - Pós-Graduação \\ S1 - Não \\ S3 - Não \\ S4 - Não \\ S8 - Não quis fazer. \\ S11 - Não \\ S14 - Não \\ S15 - Não possui. \\ S17 - Não possui. \\ S18 - Não possui.
}

\title{
4. Há quanto tempo você atua como treinador? Quanto tempo em cada categoria?
}

S1 - eu lido com o Handebol há 30 anos em Franca. Já passei como técnico em todas as categorias.

S2 - Desde 1995 eu já tinha equipe / 1996, Adulto masculino / 2000 categorias de base

S3 - 4 anos. Mirim masculino por mais de 1 ano. Infantil Masculino 1 ano.... Cadete Masculino mais um ano...2016 - Cadete e Mirim feminino

S4 - Como treinadora específica de goleiros, eu venho atuando desde 2003. Atuei 2 anos em Suzano, com a equipe feminina lá dos Regionais e Abertos. Ai depois eu retornei com essa função, porque tinha parado em 2005, lá em 2007, ai já em São Caetano, porque tinha sido atleta lá em 2002 a 2005. Ai de 2005 a 2006 eu joguei em São Caetano e Cascavel. Ai em 2007 eu retornei a São Caetano, e desde então venho atuando como preparadora específica de goleiros. Tanto em São Caetano, na seleção (júnior feminina) e agora posteriormente em Jundiaí.

S5 - 1995, a gente já começou a disputar os Jogos Regionais.. Ai eu passei por todas as categorias de Atibaia. E até hoje nós temos todas as categorias, Mirim, Infantil, Cadete, Juvenil. Junior e Adulto a gente tem um grupo só, até pelo $\mathrm{n}^{\circ}$ de atletas. Quanto tempo em cada categoria? Difícil responder isso, porque o trabalho ia mudando de polos né, então assim, as vezes era em escola municipal, então era fundamental I eu acho, hoje seria de $1^{\circ}$ a $5^{\circ}$ ano, mas já houveram grupos em escolas estaduais, no fundamental II e até ensino médio, então fica difícil eu lembrar precisamente em qual idade. Agora junto com isso, acho que é interessante saber, eu completei em março agora, 20 anos de Clube Pinheiros, e lá eu tive 10 anos de atuação no CAD - Centro de Aprendizagem Desportivo, é um programa da escola de esportes do clube, que tem quase 50 anos de tradição. Começou como recreação esportiva, mas depois teve uma formatação nos moldes de uma escola de esportes né, uma iniciação, uma vivência de bagagem motora, pra depois as crianças com 11 ou 12 anos começam a optar por uma modalidade esportiva e ai tem os departamentos competitivos dentro de cada modalidade, as principais coletivas, voleibol, basquetebol e handebol. O futebol ainda tem, mas não é federado e mais as outras modalidades olímpicas que o clube tem uma gama bem grande.

S6 - Desde 1999, há 17 anos já., eu acabei ficando com toda a base

S7 - Eu comecei a dar treino em 2004, quando eu entrei na faculdade, já para as equipes universitárias. Ai em 2006, eu assumi a equipe Juvenil Feminino na Associação Campineira de Handebol, ACH em Campinas. Depois no outro ano (2007), eu saí, e fiquei trabalhando só com escolinhas de Handebol. Depois eu voltei em 2009, e fiquei denovo com o Juvenil Feminino, até 2010, na ACH. Ai Depois eu fui pra Valinhos, em 2010, na metade do ano, e lá eu assumi a equipe Cadete Feminina. E ai em 2011, eu montei as equipes mirim, infantil, cadete e juvenil feminino. Em 2012 também e mais a equipe adulta 
feminina. Em 2013, eu só não tive a mirim (sub-12) mas ai eu montei um sub-13 no lugar e a equipe adulta só montei para jogos regionais. Mesma coisa em 2014. Ai em 2015, eu saí de Valinhos e fui pra Vinhedo. Lá, nesse ano, eu fiquei só com a equipe adulta. Agora em 2016, eu tenho praticamente todas as categorias, só não tenho mirim, mas montei um sub-13 no lugar. Tenho então, sub-13, infantil masculino e feminino, cadete masculino, sub-21 masculino e feminino e adulto masculino e feminino.

S8 - Desde 1995. No primeiro ano que eu entrei na faculdade, eu já comecei a dar treino. E em alguns anos eu peguei o time adulto também, porque a gente participou de Jogos Regionais, Jogos Abertos e ai tinha que montar equipe adulta.

S9 - 1992, 24 anos né. Finalizando isso, eu não sei dizer o tempo exato em cada categoria, mas eu passei uns 5 anos trabalhando do juvenil ao livre....depois desses 5 anos, eu dei continuidade, passando pela categoria junior até o livre...e ai eu comecei na escola um trabalho que já dura ai uns 10 anos, que a gente faz desde o mirim, infantil, cadete.

S10 - Comecei a trabalhar com treinamento esportivo, enquanto eu cursava na faculdade, de maneira mais organizada, já tem uns 15, 16 anos (2000/2001) que eu trabalho. Comecei com futsal feminino e basquetebol masculino, ambos na categoria cadete, durante 2 anos. E ai o handebol cruzou na minha vida (2002/2003) e ai eu trabalhei durante 3 anos na categoria mirim na escola. A partir dai eu venho desenvolvendo um trabalho nas categorias mirim, infantil e cadete a 10 anos. Na categoria adulto, eu trabalhei por 2 anos como técnico na equipe de Ferraz de Vasconcelos, no masculino e auxiliar técnico no feminino..então eu venho realizando esse trabalho ai a 12 anos nessas categorias.

S11 - Eu trabalho com o Handebol desde 2002, Ai em 2005, fui trabalhar em São Caetano com a equipe adulta (masc), ficando la até 2009. Em 2009, eu fui pro Corinthians, onde comecei com as equipes mirim, infantil e cadete(masc), as quais estou até hoje. Esse ano (2016), entrei na Hebraica, pra trabalhar com as equipes Infantil e Cadete Feminino. Está sendo a primeira vez que trabalho com o feminino.

S12 - em 2008 ou 2009, com a categoria adulta masculina. Ai em 2009/2010 eu atuei com uma equipe adulta em Paulínia. Em 2011, eu entrei na Prefeitura em Valinhos, com categorias de base, mirim, infantil. Estou lá até hoje com as categorias de base. Em 2012, fizemos um adulto lá também. Hoje em Valinhos, eu tenho mirim, infantil e cadete masculino e também o cadete feminino.

S13 - Bem... eu trabalho ensinando o handebol desde a época da faculdade, né? Desde 1992... Mas, aqui em Piracicaba eu trabalho com handebol desde $1997 \ldots$ sou responsável pela base, né? Trabalho com meninos e meninas a partir de 6 anos... e competitivamente sou responsável pela base masculina... categorias mirim, infantil e cadete... Trabalhei também um ano com a categoria adulta feminina... Mas, foi um projeto curto.

S14 - Eu atuo como treinador, desde na verdade quando eu jogava ainda e acabei trabalhando em categorias de base. Nem me lembro, porque já faz bastante tempo...eu tinha uns 22 anos e trabalhava em Americana com o pessoal lá, trabalhei durante uns 3 a 4 anos na iniciação esportiva....E ai eu me tornei treinador mesmo aqui, montei uma equipe pra jogar por algumas cidades que estavam dispostas a aceitar uma equipe pra Regionais em 2000 e em 2001 eu iniciei em Piracicaba e estou aqui desde então. Estou a 16 anos nesssa área...

S15 - No handebol aqui em Itatiba, eu trabalho a 26 anos.

S16 - Eu estou na prefeitura já a 32 anos e pelos uns 22 anos eu trabalho com o handebol. Desde iniciação, com a formação de crianças né, e to vindo com esse pessoal. Depois fui convidado para ser preparador de goleiro da categoria adulto feminino de Santo André, no ano 1989, na onde fiquei até 1999. E nesse meio tempo, eu tive categorias mirim e infantil feminino. Em 2001 eu retornei a equipe como treinador de goleiro e também com iniciação com crianças tanto do sexo masculino quanto do sexo feminino. E de 2012 em diante, nós estamos fazendo um trabalho na prefeitura de ir subindo essas crianças da iniciação pra categoria mirim, pra jogar o campeonato Paulista ou torneio Revelação ou 
mesmo o torneio Intra-mirim de handebol masculino e feminino. E hoje eu estou com as categorias Infantil e Cadete, masculino e feminino pela Liga Paulistana de Handebol (LPhb).

S17 - 15 anos no total, sendo 10 anos no mirim e infantil e agora 3 anos no cadete e 2 anos no juvenil.

S18 - Atuo há 1 ano e meio. Só no cadete? Não, atuo em outras categorias também, cadete e juvenil, 1 ano e meio também.

S19 - Desde 2012. Hoje eu atuo com infantil masculino e feminino, cadete masculino e juvenil masculino e já atuei no adulto também. O cadete desde 2012, o adulto de 2013 a 2015. Esse ano eu comecei com os infantis e o juvenil masculino.

5. Atua ou atuou como treinador em equipes no ambiente escolar? Em quais categorias? Por quanto tempo?

SIM

S2 - Já atuei sim. Na verdade eu comecei com o handebol escolar, eu era professor do Objetivo, e dei aula la por 19 anos. A minha primeira equipe, que eu levei pros jogos em 1996, era do Objetivo...ai mais tarde né, 2004,2007 e 2009, ai eu tive trabalho de ACD nas escolas estaduais de Tietê, Atividade Curricular Desportiva, se não me engano. E ai eu tinha as equipes, a escola Liria que era do estado, a escola Plinio que foi campeã estadual, o Objetivo que já foi terceira do estado, tudo com o feminino nesse período.

S3 - Eu dou iniciação esportiva em ambiente escolar... a gente tem uma escolinha que trabalhamos no horário de aula mesmo. Entendi... E qual é a faixa etária? 9-10 anos em uma escola... 10-11 em outra... e 11-13 em outra. Há quanto tempo você está fazendo isso... ou fez? 4 anos

S4 - eu trabalhei 1 ano num colégio, onde hoje era o $3^{\circ}$ ano, com meninos cadetes e ai eu tive uma experiência como treinadora lá, em 2006. Foi em São Mateus, colégio Satélite.

S5 - Mas em 1995, eu já iniciei os trabalhos com o handebol, montando um polo em uma escola estadual em Atibaia, já como funcionário público. E ai eu iniciei uma equipe, que fazia os eventos da Secretaria de Esportes do Estado - SP né, joguinhos da juventude, depois surgiu a Copa do Estado de SP. Era um grupo bem heterogêneo, de várias idades.

S6 - Deixa eu ver..só campeonatos municipais né, quando eu dava aula no estado, a gente chegou a jogar alguma coisinha, mas só né. Era uma criançadinha de $7^{\circ}$ e $8^{\circ}$ ano.

S10 - E ai o handebol cruzou na minha vida e ai eu trabalhei durante 3 anos na categoria mirim na escola. A partir dai eu venho desenvolvendo um trabalho nas categorias mirim, infantil e cadete a 10 anos. Porque na escola, ou nos outros locais que trabalhei, não tinha um professor específico pra cada categoria. E ai eu acabava acumulando essas funções.

S8 - Até hoje eu trabalho eu trabalho com o handebol escolar, eu continuo trabalhando em escola. E a maioria dos meus atletas saem da escola. Eu trabalho desde o pré-mirim, com 10 anos até no máximo 16 anos. Eu estou lá desde 1995, no primeiro ano da faculdade, nunca parei de trabalhar em escola.

S11 - Na escola, desde 2002. Trabalho com crianças de 10 até 18 anos né, petit, pré-mirins, mirins, infantil e juvenil.

S12 - Já atuei, na época de graduação e depois que eu sai da graduação durante mais um tempo, eu atuei em um colégio em Campinas e lá a gente tinha uma escolinha de esportes que era dentro do colégio e 
também saía pra competição. Lá eu tinha de 6 a 9 anos, uma turma de 10, 11 e 12 anos e uma turminha de 13 e 14 anos no Colégio Progresso. Eu atuei lá de 2004 até metade de 2008, se não me engano

S15 - Eu trabalho também nas escolas com equipes de competição, na faixa etária de 10 a 17 anos.

S16 - Sim, já atuei tanto na rede pública quanto na rede particular. As categorias que eu atuei na rede escolar, dando aula, foi de $6^{\circ}$ ao $9^{\circ}$ ano, atualmente. E na rede particular, eu fui contratado especificamente com o handebol. Então eu tinha que disputar os Jogos Escolares aqui em Santo André, com a categoria mirim, infantil e cadete, ou seja, de 11 a 17 anos.

S17 - Sim, no pré-mirim, mirim e infantil por 10 anos.

S19 - No escolar, eu já atuei desde 2004. e em relação a categoria, era entre o Fundamental I e o Ensino Médio. Então era de 11 a 14 e de 15 a 18 anos.

\section{NÃO}

S1 - Não.

S7 - Eu dei aula dentro da escola, mas competir no ambiente escolar não.

S9 - Não

S13 - Não, nunca atuei em escolas.

S14 - Não, no escolar eu não cheguei a atuar. Eu atuei, no início, na iniciação esportiva do município, mas não em escolas.

S18 - Não.

\section{Você desempenha outra função profissional? De que maneira essa função influencia na sua carreira de treinador? \\ SIM}

S1 - Além de técnico da categoria cadete, sou supervisor de todas as categorias.

S2 - como Secretário de Esportes, então eu to dividido ai, eu tenho um pessoal que trabalha comigo né...e ai eu vou lá ainda, a noite voluntariamente, fazer o treinamento, vou nas competições com o pessoal né, mas eu não exatamente trabalhando com toda a base nesse período, porque eu não consigo ficar la o dia inteiro, eu vou mais a noite mesmo.

S4 - Não, hoje eu estou somente aqui na prefeitura de Jundiaí e na seleção brasileira. Então, tanto aqui quanto na seleção a minha função específica é trabalhar com os goleiros das categorias da base, seja juvenil ou júnior, nesse último foi júnior (seleção). E aqui em Jundiaí, eu estou especificamente como preparadora de goleiros das categorias Infantil, Cadete, Juvenil e Júnior, feminino.

S7 - Sim, eu sou professora de Faculdade, lecionando a disciplina de Handebol em duas faculdades. Em ambas faculdades, você só trabalha com a disciplina de handebol? Não, é que a gente troca semestre né. No semestre que tem handebol, eu pego handebol, no semestre que não tem, eu pego alguma outra disciplina de prática pedagógica ou outras disciplinas.

S8 - Então, eu sou professor. Então eu trabalho na escola, dou aula de Educação Física, dou projeto de turmas de treinamento, onde eu formo equipes nas escolas que eu passo e nas escolas onde eu não dou aula, eu também formo equipes, atletas pelas turmas de treinamento e também trabalho na secretaria de 
esportes, tanto na de Cubatão quanto na de São Vicente, aonde a gente trabalha com os esportes de competição.

S10 - Eu sou funcionário público concurso pela Secretaria de Educação do Estado. Eu tenho 2 cargos: um aqui na escola Wilson Roberto Simonini, que é onde eu desenvolvo o trabalho com o handebol e outro cargo eu desenvolvo na escola Jardim Beatriz, onde eu só trabalho como professor de Educação Física. Nós últimos três meses, eu iniciei um projeto de handebol numa escola particular aqui na região onde eu moro, na categoria cadete feminino, mas é um trabalho bem novo, a gente ta fazendo pra ver se cria a cultura do handebol na escola, pra ver se aumenta o número de praticantes da modalidade. Profissionalmente são essas funções que eu desenvolvo na minha jornada de 12 horas. E você acha que essas funções influenciam no seu trabalho como treinador, de forma positiva ou negativa? Quando os dois cargos eram dentro do Simonini, eu ficava o dia inteiro na escola, eles me influenciavam positivamente, mas a partir do momento que eu tive um cargo na outra escola, até mesmo pra ter uma vida social um pouco mais favorável...acabou meio que, não atrapalhando, mas me dando um norte do que eu to fazendo, me dando um feedback diferente do que eu to fazendo. Porque, a 2 anos atrás, eu entrava no Simonini, pra desenvolver minhas atividades as $7 \mathrm{~h}$ da manhã e saía em sua grande maioria as $20 \mathrm{~h}$ ou $21 \mathrm{~h}$ da noite. ...Mas hoje eu vejo que pra minha vida pessoal me facilitou um pouco, mas pra minha vida profissional, dentro de quadra, desenvolveu alguns limitadores, por exemplo: eu não posso fazer mais uns treinamentos extras que eu fazia antes, porque nesse horário eu tenho que cumprir com minhas tarefas nos outros cargos. E o tempo de estudo né...porque eu tenho que estudar outras atividades, tenho que preparar aulas pras outas escolas...no caso da escola particular, facilita um pouco porque como é uma turminha nova...o desafio é preparar algo que seja adequado pra turma. ...Mas de uma forma geral, facilita, o que atrapalha às vezes é quando eu tenho que marcar um jogo de semana e as datas dos meus adversários bate com as datas que eu tenho que trabalhar em um dos outros cargos.

S11 - Eu sou professor de Educação Física mesmo, $8^{\circ}$ s e $9^{\circ} \mathrm{s}$ anos. Sou coordenador de Esporte e Educação Física, no colégio Vila Mesquita. Professor de Educação Física no Ensino Médio também. De que maneira essas funções podem influenciar na sua carreira de treinador? Então, quando você coordena você tem a função de organizar, de antecipar, de promover, acho que coordenação te traz essa noção ai né. A Educação Física tem a questão das habilidades motoras, e ai acaba contribuindo dessa maneira também

S14 - Aqui em Piracicaba, eu exerço a função de treinador de todas as categorias, masculino e feminino e estou agora na iniciação esportiva também. Estou agora com um trabalho de iniciação no feminino para que o handebol não pare por aqui. Tem também, o trabalho da associação. Nós temos uma associação de handebol, aonde toda a função burocrática, fica ai por minha conta.

S15 - Eu sou técnico esportivo do município, trabalho na área de handebol aqui, e também sou professor do colégio particular Next. Trabalho do $1^{\circ}$ ano do ensino fundamental até o $3^{\circ}$ ano do ensino médio. Eu acho que uma coisa ta amarrada a outra, mas eu procuro diferenciar a parte de competição com a parte educacional.

S17 - Sim, distribuição de cosméticos. Não acho que influencia não. Mas eu também desempenho outra função, que é a de professor na rede privada de escolas e isso influencia muito como treinador de handebol, porque lá eu também faço um trabalho de escolinha, de iniciação e já voltado especificamente para o handebol. Ai, quem se destaca, eu acabo levando para a minha equipe pra disputar a federação.

S18 - Sim, sou professor de futebol em uma escolinha particular. Não influencia na minha atuação como treinador de handebol.

S19 - Sim, auxiliar técnica. Isso nos dá outra visão, porque o contato com outros técnicos ajuda no planejamento do treinamento, na metodologia que cada um tem a sua. Então da mais qualidade ao treino, porque você vendo coisas diferentes, maneiras diferentes de trabalhar, de resolver os problemas durante o treinamento, durante as competições, então ajuda bastante. Em qual categoria, você é auxiliar? No juvenil e no adulto feminino. 
S3 - Não... somente isso!

S5 - Não.

S6 - Não.

S9 - Não

S12 - Não.

S13 - Não

S16 - Não 
APÊEDICE B - Transcrição das respostas do bloco de "Características dos Goleiros na Categoria sub-16" do instrumento de entrevista semiestruturado

\section{Quais as características que você considera para uma especialização do goleiro de handebol?}

S1 - Altura é a primeira coisa que eu olho. Nem sempre você acha, que tenha altura, coragem e aptidão pra posição. Quando você acha, é um talento e você tem que trabalhar.

S2 - Eu penso assim, o handebol, ele é um dos poucos esportes, junto com o futebol de salão, coletivos **que o baixinho ainda joga. Existe algumas escolas, alguns lugares que você vai fazer teste, que eles limitam a altura do goleiro..."'a se veio fazer a peneira aqui, então, goleiro acima de 1,80 e goleiras acima de 1,70 , abaixo disso não aceita". Eu gosto de começar com goleiros altos, eu vejo pela altura, mas eu não pré-determino que tem que ser goleiro. Nos mais novos, a gente coloca que todo mundo tenha a experiência. Porque eu tive grandes goleiras, que não tinham altura. $\mathrm{O}$ Maik não é o goleiro mais alto do mundo,o Bombom também. Se pega um goleiro dinamarquês, alemão, os caras batem a cabeça na trave....os nossos são mais baixos um pouco, inclusive mais baixos que os jogadores de linha. Inclusive, eu não vou lembrar o nome...tem aquela goleira de Santo André, goleirinha que jogou o universitário mundial agora... a Flavinha. É baixinha e joga muito bem. Então, a gente não tem isso nem no handebol nacional...imagina aqui em Tietê. Então eu acho que o goleiro alto, ele tem uma certa vantagem, se ele for rápido, se tiver velocidade. $\mathrm{O}$ goleiro alto eu tenho que trabalhar velocidade. $\mathrm{O}$ goleiro baixo, eu tenho que trabalhar a envergadura dele. $O$ posicionamento dele, no caso? Isso, que ele use isso.

S3 - Eu acho importante o goleiro ser alto... além de alto... se não for alto... móvel! Muito móvel! E... gostar de jogar no gol... para mim... tanto no mirim quanto no cadete.

S4 - Eu acho que dentro da faixa etária dos 13 anos pra frente, porque antes disso é importante você pensar na questão de repertório motor, em ter outras vivências, porque aí quando ele chegar no momento da especialização, ele já vai ter um repertório motor maior e aí desenvolver as características técnicas básicas que eu acho mais importantes, que são ações técnicas né, figuras técnicas pertinentes da posição e aí especializar a partir disso.

S5 - A ideia eu trouxe do Pinheiros assim, o nosso diretor é ex-goleiro da seleção brasileira de handebol, e ele brigou que tinha que ter treino específico de goleiro desde o mirim. E a gente (treinadores) defendeu que não tinha que ter treino específico de goleiro pro mirim. A gente sabe, as pessoas que estudaram a modalidade, escreveram capítulos de livros, o goleiro é um capítulo a parte, o goleiro decide o jogo, tudo isso é claro. A gente até pode dar algumas coisas específicas, mas muito mais como iniciação, como bagagem motora que treino especifico em si. $\mathrm{O}$ fator primordial pra ser goleiro no mirim, e ainda no infantil, é coragem. O menino tem que querer ir no gol, talvez pela possibilidade de queda, de dar "ponte", pode até ser divertido, eles gostam do gol. Porém quando é jogo de verdade, eles têm medo, porque hoje em dia tem atleta de mirim que chuta com potência, tenho até medo de machucar um goleiro ou uma goleira. Hoje fatalmente a principal característica é a coragem. Eu acho que as questões de prontidão, de figura, de esquadro, de técnica, de posicionamento, eu acho que isso vem numa sequência, igual você falou, depende do atleta, do nível de maturidade. Isso que você falou, seria no cadete? Sim, mas eu diria até no final do último ano de infantil, dependendo da maturidade do atleta. Lá em Atibaia, eu tenho um goleiro do infantil agora, específico, que gosta, que já veio do futebol na escola, assistiu um treino, gostou e ai decidiu ser goleiro. Menino de 14 anos, forte, alto, biótipo né... ai ele já esta tendo alguma coisa especifica de goleiro. Fora isso, no Pinheiros tem uma menina que por definição já tinha, desde o mirim, "eu sou goleira". No mirim ela tinha 1,82. Agora ela tem 1,91, infantil 14 anos. Se tudo acontecer dentro do processo ele deve ser goleira da seleção. Por enquanto ela quer, mas lá no Pinheiros tem muito atleta que tem talento, mas que acaba desistindo porque quando chega 16 e 17 anos, os pais querem outra coisa pro filho, carreira, estudo, intercâmbio e ai isso acaba não acontecendo. Como ela tem 14 ainda, isso ainda vai demorar um pouco.

S6 - Então, particularmente na base eu não faço nenhum trabalho para especializar o goleiro especificamente, mesmo porque tem muita criança querendo jogar no gol, querendo ter essa experiência, querendo ter essas vivências 
diferentes. Então a gente pega e deixa bem livre, e só orienta em relação a postura né...inclusive tem algumas linhas que defendem o goleiro em forma de "espantalho", que fica lá com o braço aberto gastando energia a toa...e o que gente tem escutado bastante é que cada vez mais o goleiro tem que tentar a assumir essa posição de "pugilista", que é com as mãos mais próximas do rosto, só em situações de $6 \mathrm{~m}$ ou pivô que ele tem que crescer mesmo, ocupar espaço...principalmente em relação a essa posição que o goleiro fica de cotovelos mais extendidos, e na hora da ação ele acaba flexionando para depois explodir né. Então pra evitar essa situação, a gente tem utilizado essa postura pra ta passando pro goleiro. Mas independente da posição inicial que ele fica...antigamente tinha muito disso né "goleiro, primeira coisa que tem que aprender é afastar a perna, joelho semi-flexionado e abrir os braços. E hoje a gente já vê alguma coisa diferente, como o posicionamento do goleiro em relação a trave. Mas eu acho que o principal pro goleiro é a coragem, de você ta ali embaixo nas traves né..porque você tem condição de passar pra criança, toda a parte técnica, questões de flexibilidade, força, de leitura de jogo, mas a coragem é difícil de você passar assim pra criança..eu acho que é uma coisa que já vem com ela. Alguns goleiros são mais corajosos e outros menos..mas eu acho que o principal mesmo é o goleiro ter essa questão do temperamento mais forte né, mais coragem..e a partir dai você vai moldando eles né, até com a genética, porque as vezes você pega goleiros mais baixos, então você tem que adaptar o posicionamento dele embaixo das traves e o próprio jeito de jogar também.

S7 - Eu na verdade trabalho com “Quem quer ser goleiro?”. Na minha realidade, aqueles que gostam de ser e que acabam demonstrando interesse, são os que jogam na posição de goleiro. É lógico que alguns aspectos físicos são desejáveis, como uma boa altura, com envergadura, ter um deslocamento rápido é preferível. Quando um goleiro muito baixinho quer ser goleiro, lá no mirim, no infantil a gente até deixa, mas depois vai tentando convencer ele a ir pra linha. E ser um jogador que tenha um pouco mais de atitude, não gosto de de goleiro que fica muito parado. Eu gosto de posicionar o goleiro, mas ele tem que ser um cara inteligente para trabalhar muito essa parte, de sempre ganhar do jogador com bola. Na verdade, tudo que eu treino, acho que o goleiro é o mais fraco que eu tenho de competência pra trabalhar. É que o eu tenho menos conhecimento, apesar de me esforçar bastante pra dar bons treinos pra eles, é mais o básico né, então é fechar posição, trabalhar com um pouquinho de finta, trabalhar deslocamentos. Primeira coisa, lá no mirinzinho né, é não cruzar perna quando vai deslocar. Ai depois, quando vai ficando assim mais especializado, eu vou tendo um pouco mais de dificuldade em trabalha com essa posição em específico.

S8 - Primeiro assim né, altura. Não adianta ser um goleiro baixinho esforçado, se ele não tem uma altura mediana fica difícil. Segundo é não ter medo da bola. E se for uma criança ágil, melhor ainda...que aprenda rápido, aí você consegue estar fazendo um bom trabalho de goleiro.

S9 - A minha opinião é a seguinte: a primeira característica que a gente observa no atleta é a sua coragem, sua coordenação, agilidade, flexibilidade...o fator altura também influencia nessa escolha...mas ele tem que gostar da posição também. Então, a princípio, as três características que eu avalio, além da altura, é esse fator coragem, em relação assim, a não ter medo da bola, a ele ser assim "solto"...enfim, pra mim são as características primordiais pra eu trabalhar alguém pra ser goleiro.

S10 - As características que eu acho que um goleiro tem que ter e que eu busco desenvolver em um goleiro, quando esse goleiro não tem aquilo que eu acho interessante, é altura, que é importante, mas não é tudo também...agilidade, flexibilidade, tomada de decisão...são essas características que eu busco no goleiro. E formar isso no goleiro, nosso trabalho lá é focado nisso...fazer com que o goleiro seja o mais flexível possível, assim ele vai ter uma amplitude de movimento importante e através de vídeos de jogos nossos, a gente acaba fazendo várias análises, e a gente sabe que aquele $1 \mathrm{~cm}$ de elasticidade, que ele consegue desempenhar, é o essencial pra tocar numa bola que nos dá um título, que nos dá um vitória. A tomada de decisão de quando explodir, quando dar um "X", quando ficar parado, quando dar o curto, quando dar o longo...pra mim essa é a principal característica, é que o busco no meu goleiro...ele tomar a decisão e errar o mínimo de decisões possíveis. Uma bola, uma defesa, pode ser o divisor de águas de você ganhar ou perder o jogo. Outra característica importante é concentração. Os goleiros que a gente vem formando ao longo dos anos, eles são em sua grande maioria, concentrados, equilibrados...os goleiros "scouteiros"...a gente acaba formando goleiro "scouteiro". Quando ele ta fora do jogo, ele ta analisando o movimento técnico do jogador. Ele vai definir, ele vai tomar a sua decisão pautada no movimento técnico do jogador.."ah, se ele andou muito, ele vai bater no longo"; "se ele abriu meia-altura, vai buscar o curto"; "esse cara chuta mais no curto ou esse cara chuta mais no longo, dependendo da diagonal ou da trajetória que ele fizer, dependendo do chute, ele vai la buscar". E a 
combinação entre goleiro e defesa. Nessa categoria eu já consigo, principalmente no masculino, fazer esse trabalho. Principalmente de "oh, a defesa é responsável por uma trajetória e o goleiro é responsável por outra". A partir do cadete a gente já começa a trabalhar com essa divisão de tarefas. Outro fator importante que a gente tem trabalhado bastante, é a agilidade de goleiro, tentar prever pra onde vai o chute... "qual o direcionamento do chute que o adversário vai tentar"...e buscar nessa situação aumentar a quantidade de defesas que o goleiro vai efetuar numa partida. A gente nos últimos anos, desenvolveu um período de treinamento específico para os goleiros, onde a gente vai pegar lá... os nossos vídeos de jogos anteriores e vamos analisar o gesto técnico que ele utilizou pra determinada defesa e o que ele possa ter desenvolvido de errado nos gols que ele tomou. A gente vai sempre pautar pra consertar aquilo que ele ta errando, melhorar aquilo que ele ta errando...elogiar, lógico, o que ele fez de certo, mas consertar o que ele ta errando..."olha, essa bola aqui eu não peguei porque eu não tava concentrado"..."essa bola eu não peguei porque eu não observei o movimento do atacante"..."essa bola eu não peguei porque eu tentei adivinhar o que ele ia fazer". A gente tenta fazer com que os goleiros não façam tipo..."a acho que ele vai chutar ali...", mas façam "Ele chuta essa bola desse jeito, então eu vou buscar ali". Nossos goleiros são chamados de goleiros scouteiros né. A gente tem um goleiro que foi formado na nossa escola que está jogando na Metodista agora, no cadete lá. E lá ele é chamado de goleiro scouteiro, é trabalho nossos. Ele geralmente fica os 5 a 10 primeiros minutos no banco analisando, e depois que entra não saia mais. Porque ele fica ali analisando o movimento técnico do adversário e o percentual de chute ta sendo ali, ou o percentual de chute ta sendo mais no curto ou no longo...dependendo da trajetória ele vai fazer determinada ação e o moleque ta fazendo a festa né.

S11 - Altura, força, flexibilidade, agilidade e coragem. As principais são essas.

S12 - Bom, eu acho que pra começar ele precisa ter um bom conhecimento de habilidades motoras, ter uma boa coordenação motora, ter explosão, ter coragem, ter uma boa leitura de movimento. Eu acho isso importante (leitura), mas eu acho uma das características mais difíceis de ensinar, essa leitura do movimento do atacante. Já que você considera difícil ensinar isso, quais as estratégias que você usa pra ensinar isso? Então, eu tenho alguns goleiros e a gente tenta dar um treinamento específico. Menos o mirim, mas o infantil e os cadetes masculino e feminino tem. Eu tenho uma pessoa que me ajuda, porém ela não é do handebol. Mas como eu fico sozinha, eu acabo precisando de um auxílio pra fazer o treinamento de goleiro. Então assim, sobre esse aspecto, que acho bem difícil, e eu tenho até dificuldade de encontrar material sobre isso, já andei pesquisando até...é assim, a gente vai criando algumas linhas assim, que a gente não sabe se vai dar certo, mas a gente tenta colocar. Então assim, na hora que a gente o treinamento, eles tem a parte específica lá com essa pessoa que me ajuda. E ai, quando eles passam pra parte mais com os jogadores de linha, é que eu tento trabalhar isso. Então eu fico atrás dos goleiros mesmo, atrás do gol, pedindo pra ele visualizar o braço de cada jogador que arremessa, pra ele verificar a característica de cada colega que arremessa ali. Fora isso, eu tento fazer com eles, exercícios em que eles não vão visualizar o braço do atacante, pra depois repetir o exercício visualizando o braço do atacante. Então eu vou pedir pros atacantes colocarem bolas em determinados lugares do gol, encobertos por um biombo. Ai depois, eu tiro esse biombo e deixo o goleiro ver. Continuam os mesmos locais de ataque, aonde eu quero que os atacantes coloquem a bola. Ai peço que os goleiros fiquem visualizando só o braço, não importa se for gol ou não, eu quero que eles fiquem visualizando qual é o movimento de braço dos atacantes. E ai eu vou corrigindo. Eu não assim, se isso realmente ajuda, mas pela experiência que a gente vem tendo, pelo o que eles falam, tem ajudado bastante. Além disso, uso vídeo, muito vídeo. Então assim, eu coloco alguns vídeos pra eles né e ai paro o vídeo e digo "ah, olha o movimento de braço...se acha que a bola vai aonde?". As vezes, não é sempre que a gente consegue usar o vídeo porque a imagem não está em um ângulo que ajude. Mas sempre eu tento ver um ou outro, pra que eles exercitem isso. Mais ou menos por esse caminho que eu to tentando ensinar isso pra eles. Porém eu acho que o mais importante é experiência mesmo,eles vão aprendendo com experiência. As outras capacidades, a gente vai conseguindo colocar pra eles. Então você treina flexibilidade, você treina potência, e eles vão conseguindo. Eu acho que muito vai ficar com a parte de experiência deles.

S13 - Falando de características relevantes né, se fosse pra falar daquilo que eu gostaria de ter nos meus goleiros, lógico que seria altura, uma boa flexibilidade, uma boa envergadura. Só que a minha realidade é trabalhar com o que eu tenho, então hoje em dia é complicado você querer achar meninos que queram jogar no gol, então aqueles que vão e que tem interesse, eu procuro lapidar de acordo com as suas características. Muitas vezes, não ideais, mas eu trabalho com a base, eu trabalho com crianças que aparecem para o treinamento do handebol, portanto a gente nunca tem o que gostaria. Mas o trabalho é sempre feito em cima das características que são apresentadas pela 
criança e pelo adolescente. Dentro da sua realidade, que características você procura lapidar? Consegue dizer assim: primeiro essa, depois aquela...etc? Dentro das características principais, como eu já disse, sempre trabalhar bastante a flexibilidade, velocidade...o goleiro tem que ser muito ágil, agilidade. E dentro disso, juntando todas essas especificidades, ai entra o treinamento da parte técnica né, movimento técnicos, movimentos de defesa de bolas baixas, médias e altas. O goleiro tem que saber todos os movimentos técnicos e fazê-los com a maior perfeição. E após o aprendizado do movimento, ai você acaba trabalhando em cima do tempo de reação né...quanto maior o tempo de reação (quis dizer menor/mais rápido) de um goleiro melhor ele vai ser. E você vai galgando degrau a degrau, até chegar em um ponto que o bom goleiro é aquele que consegue ter uma boa leitura de jogo, não só aquele que defende as bolas por si só, mas aquele que consegue fazer a leitura dos jogadores, mapeando durante o jogo, os locais de finalização do adversário.

S14 - Bom, na categoria cadete a primeira coisa que a gente precisa ver é a disponibilidade da pessoa em jogar nessa posição. É uma posição que nem todos querem exercer. As características de um goleiro de handebol são básicas. Basicamente, ser um jogador ágil, flexível e alto. Nem sempre nessa categoria do cadete, a gente vai encontrar um goleiro assim. Às vezes, é melhor você ter um pequeno (goleiro), flexível e rápido do que não ter nenhum, basicamente é isso. Nessa categoria, o ideal é que você ache aquele que esteja disposto a participar dessa categoria, dessa posição, disposto a executar essa função que nem todos os jogadores querem nessa faixa etária.

S15 - Eu acho que nas categorias menores, a criança tem que vivenciar diversos aspectos, vivencia o trabalho de goleiro, vivencia o trabalho na linha, pra dai ver as características de cada um, pra depois definir algumas posições. Eu acho que chegando na categoria cadete, o atleta já teria escolhido a sua posição, pra participar de uma equipe de handebol. Eu acho que o segredo é deixar a criança vivenciar um pouco de cada posição, pra depois ela poder escolher e nós como orientadores, tentando mostrar o melhor caminho, a melhor posição pra esse aluno-atleta. Mas pensando nesse vivência, quais as características que você acha mais importante pra dizer assim "ah, essa criança vai jogar de goleira...”? Eu acho que é fundamental ter coragem, a criança não pode ter medo da bola. E eu acho que uma das principais características do goleiro é a coragem de ir nas bolas. Alguma outra..física, técnicotática? Primeiro eu acho que tem que partir da criança, como eu já disse. Aos poucos a gente ia lapidando outras situações como reflexo né. O tamanho (altura) também é importante. Mas eu conto com um menino aqui, que é 2003, que ele não tão grande, mas as destrezas de reflexo e explosão na bola são fundamentais. Flexibilidade também é fundamental. São várias qualidades ai, que a gente vai trabalhando aos poucos, lapidando esse goleiro

S16 - Bom, para ser um goleiro, primeiro tem que ter coragem né, porque não é qualquer um que fica dentro do gol, esperando uma bola vira cara-a-cara com você. A segunda característica, ele tem que ter a visão periférica, tem que ter velocidade de reação que é facilmente treinado. Ele tem que ter um bom posicionamento dentro do gol, pra que ele tome algumas decisões diante do atacante, pra que você induza ele ao erro. Então são características que o goleiro tem que ter: inteligência, porque pra você induzir uma pessoa não é fácil, você querer que ela faça aquilo que você ta afim é difícil, principalmente com uma pessoa que você não conhece, que é o adversário; um bom campo visual, porque ele além de fazer a defesa, ele vai ter que puxar um contra-ataque ou sair com a posse de bola, olhar o seu colega de quadra bem posicionado. São vários requisitos que um bom goleiro tem que ter.

S17 - O goleiro tem que ser flexível, uma pessoa que tenha bastante elasticidade. Alguma característica específica da categoria cadete? Altura. Você falou de flexibilidade...você conseguiria elencar mais alguma características pra especialização do goleiro? Uma goleira pra mim, primeiramente ela tem que ter coragem, flexibilidade, ser inteligente, ter uma boa explosão muscular. Outra coisa, tem que ser muito esforçada e ter uma altura de média pra alta. O goleiro não pode ser muito baixo se não dificulta muito

S18 - Características físicas? Qualquer uma. Altura, agilidade e mobilidade.

S19 - Como assim? Quando você tem que especializar um goleiro, o que você acha importante? Ah, fazer um trabalho de flexibilidade, de velocidade de reação, de explosão, basicamente isso. As posturas defensivas pra cada zona de arremesso, basicamente isso. 
7. Na sua opinião, quais são as principais capacidades técnico-táticas a serem desenvolvidas pelo goleiro de handebol nessa categoria? Que patamares você espera que essas capacidades alcancem?

S1 - Perguntinha complicada, porque é uma posição tão difícil. Se você encontra o goleiro que tem altura você vai trabalhar as aptidões dele de agilidade e reflexo, bastante reflexo...nem sempre isso é suficiente. Quando ele passa pra a categoria cadete, aonde a velocidade da bola vem mais forte, ai ele já começa a ter medo, já passa pra um período de indefinição. Quando você encontra um goleiro que tenha muita flexibilidade, reflexo, habilidade e coragem, independente da altura, ele supera esses preceitos de medo e essas coisas, ai ele supera tudo isso. Eu aqui tenho algumas situações de goleiros baixos, mas com um velocidade de explosão muito grande, natural da criança, ele veio com isso, tem facilidade de explosão ta...ai você acrescenta muito trabalho técnico, de movimento, de posicionamento, de explosão, que hora que você vai dar explosão, que hora que você recebe, que situação de arremesso você vai posicionar, onde você vai posicionar no arremesso de ponta, na diagonal curta, na diagonal longa, em um arremesso de canhoto qual é o posicionamento. Você passar pra ele, qual vai ser a explosão, mas com conceito de leitura do arremesso do adversário. Eu vou te explicar: porque a bola de handebol vem com uma tal violência, com um tal força, que hoje o goleiro pra ter uma explosão pra ir defender, ele precisar ter uma leitura e sair um pouco antes do arremesso pra chegar inteiro na bola. Então essa leitura "Oh, o cara deu 2,3 arremessos... essa criança tem dificuldade de variar arremesso", então você tem a leitura que ele arremessa só de um jeito, você começa a antecipar na categoria cadete. Então você tem que dar nessa categoria, essa criança tem que começar a ter leitura do arremesso do adversário. Resumindo: noção de posicionamento variado, deslocamento, leitura do arremesso e explosão. $\mathbf{E}$ o que você espera que um menino do cadete, domine ao final da categoria? Explosão média, a coragem dominada. Se chegar no juvenil, com medo, não serve porque ai a gente vai ter muito problema com esse menino. Mas se chegar com explosão, coragem e noção básica de arremesso já ta bom. Noção de arremesso, você quer dizer, leitura? Isso, noção básica de leitura. É claro que o jogador vai ter a leitura de 2 ou 3 jogadores, no máximo, do adversário, nessa idade. Ele não tem de todo mundo não, mas no juvenil ele já começa a ter..."esse ponta arremessa aqui, assim...". No cadete, são os principais jogadores que finalizam, que são os dois meias de definição, se teve a leitura desses dois já ta bom...já arremessa e eu vou antecipar o movimento dele.

S2 - Se sabe que, independente do goleiro ser alto, no alto mais ainda, mas eu acho que a primeira coisa ainda é velocidade, velocidade de reação, trabalho de perna tem que ser muito forte, porque o goleiro é o jogador mais importante da equipe. "Vamos fazer uma grande equipe..ok, mas quem é o goleiro?" Não adianta você ter a melhor equipe do mundo, se toda a bola que for arremessada, entrar. Como eu vejo ele como o jogador mais importante da equipe, tem que ser trabalhada principalmente, a velocidade, porque se é um jogo rápido, o handebol é rápido, tem que saber repor essa bola rápida, tem que saber jogar fora do gol também..são essas duas situações ai. Eu acho que velocidade e coragem. E se a gente pensar assim: velocidade é físico, coragem é emocional/psicológica..se pensarmos em posicionamento, leitura de jogo..como você classificaria essas capacidades? A leitura de jogo, ela é muito importante..seria a leitura, o entendimento, uma coisa importante, é o goleiro pegar o jogador e entender quantas bolas são em baixo, quantas bolas são altas...ele fazer o scouting sozinho..."foram 3 ou 4 bolas ali..aquele atacante gosta de arremessar dessa forma". Essa briga, esse "par ou ímpar" que tem entre goleiro e atacante, é muito importante, além da coragem, da velocidade, ele saber olhar o outro time, fazer a leitura da outra equipe. Leitura de trajetórias, arremessos? Sim, no curto, no longo. Basicamente analisar comportamento da outra equipe? Sim, dentro dessa minha concepção do goleiro ser o jogador mais importante da equipe, eu sempre falo pra eles: "você não precisa pegar todas as bolas, você precisa pegar a bola do jogo, você precisa pegar as bolas importantes que a defesa vai deixar pra você". O time tem que ter muita confiança no goleiro. Ele é uma peça fundamental. Tem goleiro que, eu vejo assim, eles vão tomar gols, não existe jogo de handebol que termina 0x0, nas categorias adultas assim...eu não sei se existe, talvez no sub8 rs. Mas ele entender, ele repor a bola rápido, ele analisar junto com o outro goleiro, eu sempre levo mais de um goleiro...eu fico incomodado quando eu tenho que levar um goleiro ou uma goleira só. Então o time confia muito no goleiro, essa postura dele de analisar e dizer" olha, eles tão arremessando muito aqui", de avisar e organizar a defesa, o pessoal sabe que latrás tem alguém que vai segurar a onda, que sabe o que ta acontecendo. Tem que ser alguém maduro, apesar que todo goleiro é meio maluco né, segundo a lenda rsrs.

S3 - Eu acho que no mirim... o posicionamento! Eu trabalho sozinho e tenho a Dafne que estava de licença... a gente precisava ter um tempo para o goleiro... na verdade é muito difícil ter um tempo somente para o goleiro... 
a gente vai fazendo os exercícios juntos... e é difícil tirar o goleiro para faze-lo... você tem que ficar corrigindo... ensinando... quando estamos em dois... é mais fácil para fazer! Eu assumo que a gente não trabalha muito o goleiro... especifico! Mas... eu entendo ... primeiro... posicionamento... e a noção técnica dele... de observar chute.... a hora de chute.... Leitura! Isso no mirim e no cadete? No cadete ele já tem uma leitura melhor... pelo menos com que eu tenho e já tá tive... todos os goleiros que eu já tive tinham uma leitura melhor.... Posicionamento melhor... mas.... tinham essa falha de não ter um treinamento especifico! Eu não sou especialista em goleiros... eu posso pegar treino e tentar passar .... mas eu acho legal ter um para o goleiro... especifico! Um cara que tem noção .... para trabalhar com ele. E pensando mais na categoria cadete... pois já está mais especializado na posição...qual é o patamar que você espera que os seus goleiros alcancem diante destas capacidades? No final desta categoria! No cadete e mirim? Pode ser. No mirim... ter estabelecido o que ele quer... eles não sabem muito o que querem no gol.... e quando você estabelece isso... eles entendem e tem que sair dali sabendo o que é ser goleiro... é um passo maior para eles treinarem mais...Saindo do mirim ... para o infantil... eles deveriam sair definidos... especializados goleiros? Isso... no cadete... cara... como a gente não trabalha muito o goleiro... não consigo visualizar algumas coisas... mas... por exemplo, eu acho que tem que sair para ir do cadete para o juvenil.... sabendo já... dar X... antecipar... a hora que deve sair.... Que não deve... sabendo ter leitura de goleiro... isso são coisas que a gente tem que ter!

S4 - Baseado no que eu tenho feito, e na verdade a dificuldade que a gente acaba tendo, a característica técnica são as figuras técnicas. É a figura da bola alta, bola média e bola baixa. Mas esse ai é o geral, global. Porque a partir dai, eu já venho trabalhando muito mais taticamente, apesar de não ser uma fase que a gente pense em trabalhar taticamente. Mas ai eu já venho tentando implementar e assim, a princípio com algumas goleiras eu não tenho tanto problema...tenho duas goleiras, que entendem bem essa proposta tática. Então, tecnicamente eu consigo fazer uma evolução com elas de volume e repetição, aprimorando, afinando e refinando esse movimentos, mas taticamente algumas questões de leitura e de posicionamento. Então assim, eu já consigo implementar algumas questões de posicionamento, que hoje eu já acho mais importante. Inclusive é uma transição que acaba acontecendo do Infantil pro Cadete: se elas entendem essas questões de posicionamento, a figura técnica, ela vai ser refinada, mas o importante é que ela entenda que ela tem que pegar a bola, então se ela está bem posicionada ela vai pegar, independente se o gesto está correto ou não, mas o importante é que ela vá na bola, mesmo se a figura não for bonita, clássica. Ai essa questão tática eu já venho tentando inserir junto com a questão técnica, tentando as vezes priorizar um pouco a questão tática pra elas entenderem um pouco mais do jogo e da posição do goleiro. Qual o patamar que você espera que essas capacidades ao final dessa categoria? Olha, no fim da categoria cadete, eu espero que pelo menos a questão técnica ela já esteja melhor, o gesto técnico já tem que estar pronto pro juvenil. Porque no juvenil, a parte tática, o pensar o jogo, ele já tem que estar num grau mais difícil, com alguns elementos diferentes, a questão física também, ela já começa a ser cobrada. Aqui (Jundiaí), a gente já tem um trabalho físico desde o cadete. No juvenil, as questões de força, do trabalho de força de musculação, de carga, ele já é implementado. Então, quando o atleta já vem a parte técnica limpa, ai eu já trabalho outras questões relacionadas a parte física, como velocidade de reação, explosão...ai é a onde vai vendo o que precisa ser trabalhado na parte física. Então a parte técnica tem que estar bem dominada mesmo. Em contraponto, eu falo né, que eu acabo dando mais a questão tática, talvez porque a gente percebe que a questão cognitiva dessa geração nova, dessas meninas 2000, é muito ruim. Então a questão do entender o jogo, elas tem muita dificuldade. Então a gente tem que tomar muito cuidado para não atropelar, pra não dar nem demais uma coisa e nem de menos outra. É uma associação. Por isso que às vezes, a ênfase em pensar o porquê eu tenho que escolher esse gesto técnico ou o porquê eu estou fazendo dessa forma ele está mais dentro do meu treino. Então, de certa forma, ela está sendo priorizada e está sendo feita, Mas ela é padronizada, repetição, repetição, repetição...associado com o que eu dou mais ênfase, que é a questão cognitiva, que a gente tem muito esse problema com as meninas, que elas conseguem fazer o gesto mas não entendem o porque fazer esse gesto. E ai a gente tem chegado com meninas no juvenil, sem saber o que faz né.

S5 - Eu acho que a grande dificuldade é manter o posicionamento, o braço alto, atacar a bola, é jogar com profundidade e não tomar ações que ele vá pra dentro do gol, porque tem goleiro que chega na bola, mas a bola bate nele e entra. É essa questão postural mesmo. O grande defeito dos goleiros, independente da escola, é que eles mecanizam algumas figuras e realizam elas em qualquer situação, desconsiderando a variação da finalização do adversário. Quando o jogador chuta da ponta, do pivô, dos 9 e dos $6 \mathrm{~m}$, eles faz o mesmo " $X$ ”, a mesma figura e ai não tem o domínio da bola, não ocupa espaço e não tenta fazer um movimento específico pra cada tipo de finalização. 
S6 - Na verdade, no cadete, acho que até desde o infantil, a gente já busca uma especialização né. Então hoje lá em Atibaia, gente tem treinos específicos pros goleiros, uma coisa que ajudou assim, bastante a equipe. Hoje a gente tem nos treinos, nos jogos da Liga que a gente vem participando, os nossos goleiros sempre aparecendo com boas atuações, pela gente conseguir fazer esse trabalho mais direcionado pros goleiros, porque normalmente, você trabalha sozinho no horário do treino né, e ai você acaba deixando o goleiro la embaixo da trave, tomando bolada, e ai depois você quer cobrar uma reação diferente do goleiro. E ai em relação ao que eu acho que ele tem que ter, o primeiro e o principal pra mim é um bom posicionamento em relação a bola, do tronco, do quadril..bom posicionamento dele em relação a bola, dele em relação a trave, pra ele poder ta, de repente, tomando sua decisão. E uma coisa que eu passo muito pra eles hoje, é você ta buscando no jogo né, estratégias pra você ta oferecendo pro atacante...o que eu tento ta passando pra eles é que, principalmente em bolas de contra-ataque e de ponta, você tem que ta oferecendo cada hora uma coisa nova pro atacante, porque se fizer sempre a mesma coisa, ele vai identificar o seu estilo de jogo e ai fica uma coisa mais tranquila pro atacante. Então a gente trabalha bastante finta, oferecer vaselina, oferecer longo e oferecer curto...essas coisas que antes a gente não trabalhava muito...ai tem toda essa questão de visão periférica, de ter um bom passe, que antes..e hoje também, o goleiro era o primeiro...ele tem que repor a bola com muita velocidade em jogo. Então ele tem que ta ligado no árbitro, pra ver qual foi a decisão dele, pra a partir dai, também tomar uma atitude em relação a equipe, a gente coloca uma situação que, se for uma cobrança próxima da área, de lateral por exemplo, o goleiro que cobra, se for uma falta próxima da área, ele que vem. No caso, quando a gente consegue recuperar a bola, pra ele ter a máxima velocidade em direção a bola e poder retornar pra quadra e a partir dai, entra a questão periférica, eu acho muito importante, e a gente tem sério problemas, como uma menina que sai mais, e o goleiro tem sempre um lado que ele fica "bitolado", e muitas vezes não é a melhor decisão que ele tomou no jogo. Então a gente procura criar no treino, situações de retorno defensivo em inferioridade numérica, pra a partir dai, ele poder identificar realmente, qual atacante que ta mais distante do defensor e a partir dai, tomar uma decisão.

S7 - O goleiro ele já tem que saber fazer algumas coisas, como uma queda né, um espacato, um "X" bem feito, ele tem que saber se posicionar bem nas diferentes posições, pontas, meias e pivôs, saber fazer as saídas...eu não gosto de goleiro que joga em baixo da trave, então saber fazer a saída pra fechar o jogador, isso é o que eu acho que o goleiro do cadete já tem condição de fazer. Mais isso que eu consigo trabalhar com eles. E ao final dessa categoria, qual o patamar que você espera dos seus goleiros? Eu acredito que ele já tenha que ser bem consciente assim, do posicionamento pra reação dele, o que ele vai fazer. Eu trabalho um pouco, com as características de cada goleiro. Então eu tenho goleiros mais baixos, que caem um pouco mais. Tenho goleiros mais altos que trabalham mais em bolas medias e altas, não caindo tanto, mas ai eu trabalho com eles dentro das características deles. Então pro goleiro cadete, eu acredito que ele já tenha que saber fazer todos os posicionamentos, tem que saber fazer as quedas e as saídas. Basicamente é isso, pro menino ou pra menina cadete, pensando num ponto de vista ai, mais competitivo.

S8 - Reflexo, agilidade.....que mais? Ter uma boa flexibilidade pra fazer os movimentos. Acho que isso é o básico. Pensando nessas capacidades que você falou, você conseguiria fazer uma lista, dizendo assim: essa é mais importante, depois essa, etc? Olha, é difícil você falar em mais importante, porque isso varia de indivíduo para indivíduo. Então às vezes, tem um menino super ágil mas que não consegue executar o movimento, demora pra ter uma tomada de decisão. Tem outros que não tem tanta técnica, mas tem uma boa postura, uma boa colocação. Então se eu for falar assim “qual que é a mais importante”...acho que eu seu for falar mesmo, uma das mais importantes é aquele que consegue ter uma bom posicionamento.

S9 - Na categoria cadete, eu trabalho primeiramente: um bom alongamento, flexibilidade, também força...porque nesse trabalho..pra suportar o trabalho que a gente vai fazer la na frente, eles tem que estar fisicamente, bem fortes. Então a gente trabalho bastante força, coordenação, flexibilidade, são essas características...pro tático, a gente trabalha saber passar a bola bem, saber ligar um contra-ataque, ter noção do espaço do gol...que hoje a gente já desenvolve desde o mirim, então, normalmente no cadete, eles já tem uma noção das suas funções técnicas...e táticas principalmente. Como você avalia essas capacidades em treinos e em jogos? Bem, como eu disse, eu venho de um trabalho do goleiro, desde o mirim, então eu trabalho leitura de jogo, leitura do arremessador..isso nós trabalhamos na parte tática...pro goleiro já cadete, ele já tem essa especialização sim. Normalmente, eu avalio as características físicas através de alguns testes que a gente 
faz...normalmente, a gente faz os testes a cada 3 meses, teste de força, de agilidade, de reação..a gente faz pra equipe inteira..sempre buscando ver se há uma melhora física...taticamente falando, posicionamento...eu também não tenho um...como eu vou falar pra você... a gente costuma trabalhar todos os goleiros aqui em conjunto, porque como sou só eu, eu trabalho especificamente uns 40 minutos só com goleiro..então nesse tempo, que eles fazem antes do treinamento, em separado, eles tem toda essa parte técnica que eu dou pros goleiros antes do treinamento. Então, pra equipe cadete, eu avalio assim: eu precisso passar, como ele já vem pra mim no início do ano, do cadete, é um trabalho que faço a principio avaliando toda a característica dele, em que estágio em que ele está, que ele vem da escola pra mim, porque eu não pego categoria abaixo, eu só pego de cadete pra cima...então a primeira avaliação que eu fiz e faço é física e depois eu avalio tecnicamente e durante o ano eu vou incluindo o trabalho técnico, de posicionamento de gol, de avaliação de chute, de contraataque...ai eu faço um trabalho específico de agilidade, já comum que a gente faz junto com o trabalho de goleiros, com os atletas. E ai ele já consegue ingressar na equipe, porque como eu já começo trabalhar com o cadete..esse trabalho é o início de tudo mesmo..então, quando eu avalio que ele é goleiro, eu começo a trabalhar, a lapidar esse lado..lentamente até porque eu acho difícil..porque eu tiro mais ou menos 1 ano, essa possibilidade dele ta jogando no cadete, pra ele ta pegando uma condição técnico-tática boa, nas finais da competição.

S10 - A noção de posicionamento. O posicionamento técnico dele é extremamente importante, gestual, corpo sempre extendido...nunca ficar com o corpo flexionado, porque a partir do momento que ele flexiona o corpo, ele cria um aumento do campo de visão do atacante e ele demora pra chegar na bola. Esse é um problema que todo goleiro tem, ele abaixa pra depois agredir a bola, quando na verdade ele já tinha que estar de pé pra agredir a bola. Quando mais esticadinho ele estiver, mais difícil fica pro atacante finalizar. O atacante vai estar de olho o tempo inteiro no goleiro e o goleiro o tempo de inteiro de olho no atacante. Outra situação é com o advento das novas formas de atacar, pra mim o goleiro sempre foi o primeiro armador da equipe. Então, por incrível que pareça, fundamento de passe é algo que eu tenho treinado insistentemente com todos os meus goleiros. E isso não só no cadete, mas desde mirim até o juvenil. Mas no cadete, nessa categoria pra mim, o goleiro acaba sendo um armador né. Ele faz a defesa, já da o tiro de saída, arma o contra-ataque. Então ele precisa saber fazer essas situações de passe de média e curta distância e de longa distância no contra-ataque direto. Vejamos, deixa eu pensar aqui outra situação importante....o aspecto físico do goleiro né. A gente vê, já nessa categoria, alguns atletas acima do peso né e acaba atrapalhando, dificultando né...porque hoje o jogo ta muito dinâmico. Então no mesmo ataque, o goleiro pode ser obrigado a desenvolver três a quatro intervenções. E se a gente um goleiro acima do peso, um goleiro que não vai ter essa disponibilidade de cair e levantar, cair e levantar...a chance desse goleiro tomar o gol vai ser muito grande. Então a gente briga muito e treina muito nos nossos goleiros, o aspecto tático, o aspecto físico...sobre estar no peso ideal...pra poder tirar o máximo que esse goleiro tem pra dar pra gente. A coordenação motora é algo que a gente vem trabalhando nos últimos anos né, começou a estudar um pouco de movimentos coordenativos para os goleiros. Nessa fase, a gente percebeu o que os goleiros precisam porque o corpo já memorizou muito movimento e se a gente não da um trabalho coordenativo esses movimentos já começam a ser executados de maneira equivocada onde o goleiro vai despender muita energia para movimentos simples, como saber fazer um " $X$ " na hora certa né, ou você fazer um salto para defender um bola de pivô, você avançar até a linha de $7 \mathrm{~m}$ e depois recuperar quando o atacante tenta dar uma "vasoca". Então a gente vem fazendo esse trabalho de aspectos coordenativos, para que o goleiro possa ter a sua coordenação o mais afinadinha possível. Vale ressaltar também, que o que a goleira da Angola fez ontem no jogo, são exceções né. Tem goleiros que são gordinhos e conseguem fazer grandes defesas, mas eu prefiro desenvolver nos meus goleiros, mantê-los dentro de um peso ideal. Pra que eles possam desenvolver o melhor do handebol deles.

S11 - Nessa idade, eu acredito que o goleiro já tenha que estar na fase final de formação básica ai né, então... noções de figuras (técnicas), noções de espaços, de deslocamento, de lançamento, também noções de análise de estatística pra fazer análise do arremesso do adversário, trabalhar com scouting, enfim...com essas leituras também é importante. Pensando na categoria cadete, qual o patamar que você espera que os goleiros alcancem ao final da categoria? O patamar que a gente aguarda, é o que eu disse, já é o final da formação básica ali, já indo pra avançada. Então eu acredito que ele já tenha essa formação toda ai, já definida ai de posicionamento, noções de espaço, noções de deslocamento, noções de lançamento...eu creio que já tenha que estar totalmente desenvolvida ai, entendeu. Esse é o patamar que eu espero entregar o atleta lá pro juvenil. E ai no juvenil, já estar trabalhando com as questões avançadas ai, de tempo de reação avançado, lançamento avançado, enfim...já estar melhor nessas questões ai. 
S12 - Eu acho que um bom deslocamento, uma boa noção de posicionamento, um bom lançamento, ele tem que ter...e uma reação rápida né, pra efetuar as defesas. Basicamente isso. Essas somadas as que você já citou anteriormente? Isso, exato. Como você falou em técnico-tático, eu acrescentei essas e não repeti as outras, mas todas são importantes. Qual o patamar que você espera que o seus goleiros alcancem no final da categoria? Olha, que eles tenham força né, quando subirem pra uma categoria que já vai exigir um pouco mais de força né, que eles tenham um bom deslocamento, que eles consigam ter essa visão e noção, noção de posicionamento...que isso seja bem definido assim neles. Os meus goleiros, especificamente, eles estão...na verdade eu tenho um goleiro do cadete masculino e no feminino duas. Todos no primeiro ano de cadete. Então é uma experiência né. Eu até comentei com essa pessoa que me ajuda no treinamento, que esse ano vai ser de experiências mesmo assim, pro ano que vem a gente conseguir ver o que ta certo, o que ta errado e a gente conseguir melhorar o treinamento. A gente já conversou, agora que eu fiz a aplicação do $2^{\circ}$ momento de testes né...fiz um no começo do ano e um agora. Então depois que eu vi os resultados, a nossa foi conversa foi essa mesmo, que esse ano foi um ano de bastante experiência mesmo, pra gente ver o que da certo, pro ano que vem, que é o ano $2^{\circ}$ ano da categoria deles.

S13 - Primeiramente, para mim o goleiro de handebol não tem que ser um pai-de-santo, pra sair adivinhando aonde que as bolas vão ser arremessadas. Então, principalmente, o goleiro de handebol tem que esperar o arremesso para a definição do seu gestual técnico, pensando na categoria em que trabalhamos, não tendo comparação com as categorias maiores, aonde ai já entra a combinação defesa-goleiro entre outras coisas. Em categorias de base, o goleiro tem que aprender a esperar o tiro, a esperar a saída da bola do jogador, para que ele defina o seu movimento técnico, o seu gestual técnico. E ai, em cima dessa leitura de jogo, fazer as suas defesas. Quando se fala em capacidade técnica de um goleiro, já está se englobando que ele tem que saber perfeitamente, a execução de uma defesa baixa e qual o movimento técnico dessa defesa baixa, o movimento técnico de uma defesa meia-altura, o gestual técnico de uma defesa alta. E ai você vai seguindo os passos de uma defesa baixa, mais específica, avaliando o gestual do espacato, trabalhando um gestual de um " $\mathrm{X}$ " baixo, uma defesa mais posicionada, trabalhando o gestual técnico de um " $\mathrm{X}$ " alto. E por consequências, arremesso de ponta: qual a movimentação, qual a colocação, onde o goleiro se coloca quando de um arremesso de ponta, de um arremesso de meia ou de um arremesso de centro, a angulação que ele tem que estar, levando em consideração qual o posicionamento do seu corpo que ele tem que estar em relação ao atacante. Então, essas coisas são primordiais, para que o goleiro seja lapidado, seja feito...aprendendo a parte básica e em cima disso, ir galgando degrau a degrau. E qual o patamar que você espera do desempenho deles ao final desta categoria? Agora, sobre o que esperar de um goleiro...pra mim o goleiro tem que chegar no final da categoria cadete, ali com 16 anos, tem que estar pronto já, com todos esses atributos muito bem fixados, treinados e executados pra ser considerado de bom a excelente goleiro. Porque a partir dai, quando ele passa pra categoria Juvenil (sub-18), o que ele vai ganhar é sim a experiência de jogo. Então ele vai ter que atrelar, toda aquela parte técnica que ele aprendeu durante os 4,5,6 anos que ele vai treinando né, desde a categoria mirim, toda essa parte técnica, inicial tática. Ai no Juvenil, ele vai relacionar isso juntamente com a parte tática, como a gente estava falando, da combinação defesa-goleiro, que a partir dessa categoria (juvenil) já se torna muito importante, devido a velocidade de bola e outros atributos dos jogadores de ataque.

S14 - Na categoria cadete, a preocupação maior é com a condição física dele né, pra que ele execute os movimentos com agilidade maior. E tecnicamente, as movimentações básicas do handebol pra bola baixa, alta e média . Taticamente, passar pra ele ter a visão de posicionamento, de saber onde está a bola, pra que se posicione numa condição melhor pra fazer a defesa. Além de tentar visualizar a bola antes de fazer a movimentação, e não deixar que a bola atinja ele sem a função de ele estar ali sabendo, mais ou menos aonde que está indo a bola. Qual o patamar que você espera que os seus atletas alcancem ao final desta categoria? O esperado de um jogador nesta categoria, é o esperado de um jogador em todas as categorias: que ele esteja preparado pra fazer parte da categoria de cima. Então por exemplo: saindo da categoria cadete, ele já tem que estar com as condições, do ponto de vista do treinador, que ele já tenha condições de participar da equipe juvenil, no caso que seria a categoria acima da cadete, para que ele possa ali já desenvolver um bom papel, pra que ele possa começar os trabalhos no juvenil.

S15 - Bom, não importando a categoria, eu acho que o goleiro é $60 \%$ de uma equipe. Ele, além de defender as bolas, é quem inicia as bolas de contra-ataque, principalmente na categoria cadete, aonde você pode vencer as partidas nas saídas de bolas rápidas, na transição da defesa pro ataque, ou no ataque sustentado ou no contra- 
ataque, o goleiro é fundamental. Mais alguma? Eu acho que a personalidade e a liderança de um goleiro são fundamentais para ele ter sucesso dentro da equipe. Não pode se abater, o goleiro vai pegar 20 bolas difíceis e vai tomar um gol no final e erra, ai todo mundo vai culpa-lo pela derrota. Então essas habilidades para lidar com o grupo são fundamentais para que ele não se deixe abater e faça com que a equipe tenha confiança pra vencer as partidas. Ao final dessa categoria, o que você espera do nível de desempenho dos seus goleiros? O que ta mais difícil nos dias de hoje é você conseguir manter um grupo. Por exemplo, esse ano nós começamos com um grupo de 22 atletas cadetes na LHESP e hoje eu conto com 16 apenas. A perseverança e o comprometimento dos alunos está muito difícil, então se a gente conseguir manter um trabalho de continuidade, trabalhar com esse goleiro vários aspectos, como já te disse, pra que ele vá evoluindo cada vez mais e faça parte das nossas equipes adultas.

S16 - Um bom posicionamento, velocidade de reação, velocidade de explosão e a capacidade dele fazer uma movimentação que seja diferente pra diversos tipos de chute. Então vamos supor, não fazer apenas, aquela defesa básica. Então tem que dar a capacidade pra ele, pra que ele aprenda outras movimentos e não aqueles básicos, pois o que importa é você chegar na bola e defender essa bola.

S17 - O posicionamento. Mas somente do goleiro ou em relação a outros jogadores? Em relação a outros jogadores, situação de jogo. Como você avalia o desempenho dos seus goleiros? O "Zóiometro" é uma técnica boa. Você utiliza alguma outra técnica, como anotação ou algo do tipo? Scouting? Não, não uso porque eu sou sozinho. Quais os patamares que você espera que o seu goleiro alcance ao final da categoria cadete? Tem que chegar em um nível alto, devido a intensidade de treinamento. E o que você considera um nível alto? Excelência de movimento, com certeza. Você falou de posicionamento...você conseguiria elencar mais alguma característica? Fale mais sobre o posicionamento. As valências físicas que eu acho necessária para um goleiro ter um bom desempenho, primeiramente ela tem que ter uma excelente visão periférica, uma noção muito boa do jogo em si, principalmente como orientação defensiva, como a orientação da sua defesa justamente de bloqueio, onde o bloqueio de uma jogadora de linha pode influenciar em uma bola na posição 2 da defesa do lado direito, a defesa fecha o curto e a goleira fecha o longo...então essa orientação a goleira tem que ter essa prática de jogo muito grande. E ela tem que ter essas valências físicas que eu falei, de força explosiva, uma resistência aeróbica e anaeróbica muito boa, devido a algumas reposições de bola e sabedoria pra poder saber jogar também. Referente ao posicionamento, eu acho que é o segredo do goleiro. Porque o goleiro muitas vezes, tem muita força explosiva, mas não tem noção de tempo e espaço e de posicionamento, ai isso ai dificulta. Se eu já tenho um posicionamento muito bom e já tenho uma noção boa, de onde se colocar, de posicionamento de bola, desenhar o seu atacante e perceber como que vai acontecer, tipo uma premeditação daquilo que o atacante pode realizar, isso dai faz com que o goleiro se destaque.

S18 - No aspecto técnico, posição do goleiro, ele tem que ter uma posição muito boa. No tático...eu acho que ele tem a ver com a posição dele mesmo, com ele estar bem posicionado mesmo pra fechar o ângulo do atacante e do arremessador. Como você avalia essas capacidades em treinos e jogos? Com o número significativo de acertos, a gente observa as posições dele, se ele posicionou certo, se ele saiu certo, se ele fez o fundamento certo da posição. Qual o patamar que você espera que o seu goleiro alcance ao final dessa categoria? A gente sempre quer a excelência né, então seria isso a excelência.

S19 - Olha, no cadete já começa a aparecer jogadores com uma potência de chute maior. Então a velocidade de reação, explosão...isso precisa ser trabalhado melhor. E as posturas defensivas mesmo. O que a gente vê aqui é que a nossa equipe começou a competir esse ano na categoria Cadete, então os meninos estão começando a ter uma noção de gol esse ano, de ter um treinamento de goleiro esse ano. Então a gente vê que eles têm dificuldade nessa questão, mais em posicionamento mesmo. A maioria dos goleiros já veio das categorias menores? No cadete, não. Como você analisa essas capacidades, nos treinos e nos jogos? Então, eles tem um treinamento específico de goleiro, com outro professor aqui. Então eu só analiso eles em situação de jogo. E essa treinadores de goleiros, vem todos os treinos? Ela trabalha com eles dois dias na semana, na segunda e na quarta e na terça e quinta comigo. Nesses dias, enquanto a equipe está aquecendo, eles estão fazendo uma parte específica, reproduzindo alguns exercícios do treinamento anterior. Qual o patamar que você espera que seus atletas alcancem ao final da categoria? O que a gente faz aqui é assim: vai pro jogo e se a gente observa que eles não estão fazendo alguma coisa, como a postura errada ou se a velocidade de reação ta lenta, ai eu vejo 
e passo pra professora pra ela tentar introduzir alguns outros exercícios pra ele. E eu tenho notado uma evolução bem grande, a partir do momento que eles começaram a fazer um treinamento específico. Mas como o meu cadete, iniciou agora, considerado uma idade até mais avançada pra iniciar a prática esportiva, então a gente sabe que eles vão ter uma evolução é óbvio com o treinamento, mas talvez, não alcance um patamar elevado por conta do déficit de treino, de padrão motor que ficou perdido nesse tempo. Então não tem como. Na verdade, a evolução deles tem sido surpreendente, se considerar que eles começaram do zero, com 15, 16 anos. Então, tem evoluído bem, mas a expectativa não tem como eu te responder até por isso...tem que ver se eles vão continuar na modalidade. Como você faz a sua análise durante os jogos? A gente faz filmagem dos jogos deles, depois a gente estuda em cima das filmagens e passa também alguns tapes pra eles, pra eles se enxergarem também. Isso ajudou bastante, na correção de algumas posturas que eles estavam tendo em determinadas regiões de arremesso.

\section{O que um goleiro de handebol deve observar durante o ataque do adversário? E durante o ataque da sua equipe?}

S1 - Do adversário, é isso que eu te passei ta, ter leitura básica dos arremessos, concentração total, porque essa cidade de cadete tem hora que das umas "voada" "some" "da umas apagada" e nem sabe o que fazendo ali. Você tem um garoto com uma certa concentração, que ta bem focado naquilo que foi passado, já ta numa situação defensiva muito boa. No ataque da minha equipe, aquela explosão de saída, eu vou te explicar como que eu gosto: quando tem um tiro lateral ele que vai cobrar; qualquer tiro, uma falta nossa, ele que vai cobrar, porque os nossos pontas já sai, o pivô já vai também e os nossos armadores já sai em transição combinada. Então ele faz parte dessa transição combinada, eu dou esse poder pro goleiro. No caso, você considera o goleiro, como o primeiro atacante? Isso, o primeiro atacante em qualquer situação adversa, ou com falta, tiro livre, qualquer situação, lateral, é ele que vai dar, porque é ele que vai dar...pra quem ele soltar essa bola, qualquer armador que for levar essa bola, independente pra quem ele passar, é da onde que vai sair o movimento combinado.

S2 - A primeira coisa que se fala para o atleta é o braço né, se o braço ta aberto ou fechado. A gente estuda com os goleiros, põe elas sentadas e diz: "oh, se o atacante estiver com o braço aqui, aonde que ela consegue por essa bola?" "Se o atacante ta caindo pra esse lado, e a nossa defesa ta fechando, existe a necessidade de você sair e voltar depois?”. Então a questão de alavancas né, a gente estuda as alavancas. Agora, quando nós estamos atacando...eu não sei os outros técnicos que vc ta estudando, mas as nossas goleiras, elas olham muito as goleiras adversárias e orientam as nossas atacantes, quanto ao arremesso: "oh, se ta errando o arremesso, olha o pé de apoio que ela ta colocando". Por elas treinarem os fundamentos, treinarem as movimentações, elas orientam as nossas atacantes.

S3 - Cara... ele deve observar quem é o chutador... de onde que ele está chutando... por onde ele está chutando... geralmente tem 2, $3 \ldots$ que mais finalizam... e o que está ocasionando, né? Ajudar a defesa... falar com a defesa! Você acha que o goleiro tem alguma participação no ataque da sua equipe? Em algum momento? Sim... é o primeiro passe.... é ele que começa o ataque... se ele defender essa bola e fazer o primeiro passe bem feito... até mesmo no ataque... hoje... está usando o goleiro linha... que eu acho legal... e bem treinado é ótimo... mas... nessa categoria não utilizamos ainda... é como eu falei... fundamento! Sem fundamento não tem jogo.

S4 - Na categoria cadete, o que eu tenho mais cobrado e que eu acho mais importante, são algumas relações que eu já estou pensando em longo prazo...que é a questão do posicionamento em relação ao braço do atleta. Então, quanto mais o goleiro estiver bem posicionado em relação ao braço do atacante, mais ele vai estar se favorecendo em relação aos posicionamentos. É o que gente tem mais trabalhado, a questão das diagonais, de longo e curto. Então a gente cobra isso, porque a dificuldade que a gente acaba tendo...quando eu cheguei em Jundiaí a 1 ano e meio, o que a gente percebe é isso: as atletas do juvenil e júnior não sabem fazer isso, porque a dificuldade já vem desde o infantil. E ai no cadete o reformo é em cima disso, porque justamente as minhas goleiras cadetes, são infantis. Cadete mesmo, hoje eu só estou com 3, mas na verdade eu tenho 6 goleiras. Então as cartilhas são as mesmas, quanto melhor ela estiver posicionada em relação ao braço de arremesso do atacante, melhor vai ser a vantagem dela em relação a essa defesa. No ataque da minha equipe, cada vez mais a gente colocado a situação de reposição de bola rápida para a transição ser mais eficiente, e ai gente tem trabalhado muito isso e tem funcionado. Então as goleiras, elas ficam inseguras em ser as primeiras atacantes, seja em 
lançar as bolas direto, ou um lançamento de transição. Então a gente vem incentivando, que quanto mais rápido elas fizerem isso, que quanto mais a participação delas é efetiva em relação a essa passe, a possibilidade do gol é muito maior, porque a gente chega com uma situação de retorno defensivo ruim das outras equipes né.

S5 - Eu acredito que no infantil, como é mais jogo-livre, o goleiro ainda não consegue dominar o bloqueio defensivo "Oh, a defesa pega o longo e eu o curto". Talvez no cadete, já seja possível esse processo. Não acredito também que no cadete, os goleiros já saibam fazer scouting "oh, o atacante arremessa $90 \%$ no longo ou curto, alto ou baixo". É a minha visão né, embora em Atibaia a gente não faça isso, a gente costuma dar algumas informações específicas pros goleiros "oh, esse jogador arremessa mais lá, presta atenção nisso". No $7 \mathrm{~m}$, a gente orienta "olha o braço". Por exemplo, goleiro de infantil eu falo "vai na bola cruzada" quando é $7 \mathrm{~m}$ ou ponta. Porque dificilmente nessa idade eles vão ter o domínio de ameaçar e levar o goleiro pro longo e arremessar no curto seja em $7 \mathrm{~m}$, ou ponta. No cadete, você consegue até dar mais orientação em relação a isso, mas o meu goleiro do cadete ainda não consegue fazer isso não. Então, que tipo de informação você da ao seu goleiro do cadete: trajetória,braço, como funciona isso? Todas essas informações, se o atacante faz a diagonal longa, normalmente ele chuta cruzando né, também falo bastante sobre o braço de arremesso. $\mathbf{E}$ durante o ataque da sua equipe? Durante o ataque da minha equipe, você diz, atacar $7 \times 6$ ? Pode falar de maneira geral, se você acha que ele participa do processo ofensivo da sua equipe. No infantil e no cadete, não acredito não.

S6 - Primeiro a bola que é o mais importante né. No jogo, quem tem a bola é quem tem mais responsabilidade. Então o goleiro tem que primeiro orientar a defesa, como muitas equipes o utilizam, tem que primeiro diminuir espaços. Eu vejo também muitos goleiros que orientam a sua equipe em relação ao pivô, as ajudas, que eu acho é muito importante também. Mas o principal ai pros goleiros é identificar a bola e a partir dai, modificar o seu posicionamento em relação ao atacante. Tem que ficar sempre ligado também, as características de cada um no jogo...de repente você tem um armador que não é tão alto,mas que tem bolas rápidas e ai você tem que estar mais preparadas pra um arremesso de $1^{\circ} \mathrm{e} 2^{\circ}$ passo, porque as vezes os goleiros fazem o deslocamento mas não tao preparados pra uma bola mais rápida. Então eu acho que é importante identificar as características de cada jogador, um chute com os três passos, um chute mais em suspensão, uma bola apoiada, um chute"em cadeira", então ele tem que ta mais pronto pra aquele jogador em especifico, pra ta tomando uma decisão mais rápida, então nesse caso se tem que ta preparado pra aquele atacante. Acho que é isso, é o que o falo pras minhas menina né. Apesar de que eu sou técnico de goleiro tanto do masculino quanto do feminino, eu tento passar essas coisas pra eles né, primeiro um bom posicionamento, que acho que é meia-defesa já, e a partir dai, é tudo uma questão técnica né, a explosão, a flexibilidade que se tem que ter pra chegar na bola, uma tomada de decisão que se tem que ter em função de cada jogador, acho que é mais ou menos isso ai.

S7 - Ah eu tenho um scouting que eu trabalho com eles, que mostra da onde o jogador saiu e pra onde foi o arremesso. Então é da onde sai a maioria dos chutes do adversário, e qual é a trajetória que ele toma pra determinado chute. Por exemplo: o Meia esquerda, quando ele faz a trajetória para dentro, a maioria dos chutes dele são aonde, no curto ou no longo, em baixo ou em cima. Eu trabalho com esses critérios pro goleiro. $\mathbf{E}$ durante o ataque da sua equipe? Sim. Eu não trabalho com goleiro linha, mas a saída pro ataque começa pelo goleiro. Então, eu trabalho muito essa parte do goleiro buscar a bola rápido, cobrar um lateral mais rápido, pro ataque conseguir dar essa sequência já em progressão, indo pra cima com velocidade.

S8 - Nas categorias menores, é até mais fácil de estar analisando porque os atletas estão em fase de amadurecimento, então o que a gente passa é pra eles estarem analisando a frequência de arremesso de atacante, de onde ele costuma arremessar, de qual posição..."ah quando ele bate da esquerda pra direita ele chuta em tal lugar" "se ele esta de frente de pro gol, ele chuta de tal forma". E ai aumenta a porcentagem de defesa né, porque ai ele tem condições de se antecipar e defender né. Nessa categoria, é até mais fácil fazer um scouting do que numa categoria mais acima, num júnior ou no adulto por exemplo, onde o atacante ele tem mais recurso né. $\mathbf{E}$ durante o ataque da sua equipe? Sim, com certeza. O primeiro ataque já vem do goleiro né. Quando ele defende a bola e repõe ela rápido, a gente consegue fazer contra-ataque. Ele é nosso primeiro atacante. Assim que ele faz a defesa e já lança a bola la na frente ou ele já repõe a bola em jogo rápido, isso com certeza ele conta muito pro nosso ataque, tanto que a gente trabalha bastante isso pra poder fazer a defesa. 
S9 - O goleiro tem que observar: o arremessador principalmente...quais são as características dele, qual a bola de segurança dele. Normalmente a gente, quando ta trabalhando com dois goleiros, a gente faz um pequeno scouting, pra ta fazendo essa avaliação, pra que ele consiga, pelo menos tentar essa defesa, a observação é fundamental. Então a primeira observação que a gente faz é do arremessador...as características dele, se é destro, se é canhoto.... a posição do chute, se ele prefere o longo alto, se ele prefere o curto...todas essas avaliações são feitas em conjunto com os outros goleiros ...um que joga e outros que está observando, para depois tentar fazer as defesas. Esse é um trabalho que eu utilizo aqui na minha equipe, que já começa na categoria cadete...então a gente vai implantando aos poucos que ele observe bastante porque é muito fundamental que ele observe, porque se não, ele não consegue realizar...não é simplesmente realizar aleatoriamente...ele tem que ter uma leitura correta desse arremessador pra tentar a defesa. E durante o ataque da sua equipe? Bem, ele é o primeiro atacante né, então ele vai tentar uma defesa, e normalmente vai fazer esse ataque funcionar, um contra-ataque ou um ataque sustentado...mas ele tem que ter essa noções de como sair, assim que ele realiza a defesa e recupera a posse de bola, ele é o primeiro atacante.

S10 - Ao analisar o vídeos de outros goleiros, eles começam a observar que a trajetória, geralmente, é o que vai definir o chute do atacante. E ai eles começam a observar trajetória, observar gesto técnico e a partir daí fazer a leitura e tomar a decisão. A gente costuma dizer a eles que a tomada de decisão vem através das informações que ele conseguiu obter em relação ao movimento. Se ele faz essas análises, ele vai ter uma possibilidade maior de sucesso. E durante o ataque da sua equipe? Ele vai iniciar toda a minha situação de ataque, mesmo quando toma o gol, uma vez que ele repõe a bola com velocidade a gente vai conseguir chegar com superioridade numérica no campo de ataque. E ai eu prefiro, o meu time, ser treinador para passar o menor tempo possível no ataque e recuperar a posse da bola na defesa. Nesse sentido, mesmo que eu tome o gol, se o goleiro consegue repor a bola o mais rápido possível pra que a gente tenha o tiro de saída...fatalmente a gente vai chegar com superioridade numérica. Se ele faz uma defesa, ele já tem de duas e três a situações de passe. E ai ele vai tomar a decisão o mais rápido possível. Ele vai ter desenvolvido nos treinamentos, as atividades que vão levar ele a tomar a decisão mais eficiente. Nem sempre essa decisão da certo, mas quando da certo, fatalmente a gente fica em vantagem.

S11 - Posicionamento em quadra, posicionamento do braço, posicionamento do tronco, quadril, enfim...tudo isso influencia no movimento né...rotação, tudo isso. Se ele puder observar tudo isso, já contribui muito ai pra que ele possa se posicionar bem ai pra fazer a defesa. $\mathbf{E}$ durante o ataque da sua equipe? Bom, dependendo do conhecimento tático, do jogo, das ações que a gente tem que fazer...ele pode participar sim, ele pode falar sobre posicionamento, enfim, ele tem participação sim. Essa participação então seria mais no campo da orientação, então? Num campo de orientação de mesmo

S12 - Eu acho que ele deve observar o deslocamento do atacante, pra onde ele está se deslocando. E observar também a sua defesa, porque eu acho também que o goleiro ajuda muito, nessa parte de organização de defesa. Isso então, é a função do goleiro durante o ataque adversário? Não, eu não acho que seja função do goleiro, mas ele pode ajudar. Mas o principal, a hora que o atacante vem, o principal é observar o deslocamento do atacante. Mas o resto ele só pode ajudar, ai vai depender da categoria e no cadete isso já um pouco mais difícil. E durante o ataque da sua equipe, o goleiro tem alguma participação? Eu incentivo muito os meus goleiros a falarem com o pessoal da linha, eu incentivo bastante isso. E quando o meu time está no ataque...mais pela visão do goleiro ali, que ta conseguindo ver quase tudo né, de uma forma um pouco privilegiada. Então assim, os meus goleiros falam muito... "Tá aberto, bate de fora". Eles tem muito essa coisa de falar com o pessoal que está atacando.

S13 - Basicamente, o goleiro dessas categorias ele não deve tirar o olho do braço de apoio da bola. Uma das coisas que eu peço muito pros goleiros é: esqueça o corpo do jogador, esqueça qualquer gestual dele, fixe o seu olhar apenas no braço dele. Eu acho que todo goleiro pode influenciar o ataque da sua equipe. Especificamente no meu time, ele influencia quando ele lança ou não lança a bola para contra-ataques ou em saídas de bola com passes certos ou errados, como eu já tive em jogos, o meu goleiro com posse de bola saindo e fazendo o lançamento próximo a área de $6 \mathrm{~m}$ na mão do jogador adversário, quer dizer...influencia e muito 
S14 - Ele precisa observar a movimentação do ataque, pra saber aonde que a bola está, e pra saber sempre aonde que está o jogador em posse da bola. O que esse jogador pretende com a bola, se ele pretende atacar ou se ele pretende passar. Porque se ele pretende atacar, ele tem que se preparar pra uma defesa na distância em que ele está. Ou se ele está vendo que a trajetória é para um passe, ele precisa estar vendo também qual é o jogador que está livre para receber essa bola pra que ele se posicione em condições de defesa. E durante o ataque da sua equipe? Então, a gente costuma dizer que o goleiro é o nosso primeiro atacante, é ele que retem a bola e coloca ela em jogo...logo, quanto mais rápido ele coloca ela em jogo melhor. Assim também, como numa defesa...se ele conseguir pegar essa bola numa falta perto da área ou num erro do adversário, ele já vai conseguindo lançar essa bola pro contra-ataque....e ai já tem uma participação efetiva num gol né.

S15 - Nessa categoria procuramos trabalhar o básico né, como o braço sempre levantado, esperar a definição do arremesso pra fazer a posição. Nas bolas de ponta, segurar o máximo o chute, porque eles tem alguns vícios né, na hora de se posicionar para o chute, erguendo perna a hora que não é pra erguer perna....e ai a gente procurar orientar eles da melhor maneira, pra que as coisas deem certo.

S16 - A princípio, um goleiro ele tem que trabalhar com a própria defesa, orientando que essa defesa feche um lado do gol e ele se posicione do outro. Isso é difícil, principalmente em categorias menores, porque existe a empolgação da defesa e a empolgação do goleiro. Uma outra característica que o goleiro tem que ter, é observar a característica do chute, o tipo de arremesso que o adversário faz, porque dificilmente nessa categoria, existem mudanças do chute, variações de chute, uma quebra de trajetória, há um trajetória diagonal de arremesso. Então, fica fácil você olhar o adversário e você marcar a bola dele, nessas categorias de base principalmente. Quando sobe um pouquinho, principalmente no juvenil, ou mesmo no junior ou no adulto, o trabalho já é de quebra de punho, de quebra de arremesso, o que dificulta um pouquinho mais o arremesso. Mas principalmente o que tem que ser trabalhado, entre goleiro e defesa, é a defesa fechar um lado do gol e o goleiro ficar do outro. E durante o ataque da sua equipe? Com certeza.Nós trabalhamos pra que o goleiro tenha um grande campo visual total de ataque. Porque essa percepção de alguns jogadores que saem para o contra-ataque, então esse lançamento tem que ser rápido e preciso. Também trabalhamos a reposição rápida, na hora do gol, pra que faça uma saída rápida, pegando a equipe adversária no retorno defensivo e assim poder explorar algum tipo de buraco na defesa.

S17 - O posicionamento da sua equipe defensiva, depois o deslocamento de atacantes que vão estar chegando nas laterais e depois quem está em posse de bola. E durante o ataque da sua equipe? Primeiro fazer a ligação direta. Se não der, fazer o contra-ataque sustentado. Olhar a movimentação do primeiro atleta que está saindo em contra-ataque e assim vai ser sucessivamente, se não der certo a ligação direta, faz o sustentado. Você acha que o goleiro tem que passar informações para o time, durante o ataque? Com certeza. Que tipo de informações? O posicionamento ofensivo da equipe adversária e a movimentação de circulação. No ataque da sua equipe, não.

S18 - Eu acho que posição onde ele vai arremessar; a dificuldade da defesa dele, aonde está acontecendo os ataques e aonde os caras tem mais facilidade pra arremesso, pra finalização, aonde que o atacante consegue entrar na finta pra estar sempre ajudando a equipe né. No ataque da nossa equipe, ele vê a dificuldade da defesa da outra equipe e indica ao ataque onde que é a melhor opção.

S19 - Ele tem que observar...mais ou menos fazer um scoutizinho básico do jogador...observar a postura do braço pra saber onde vai o arremesso. Geralmente, é muito difícil você achar atleta no cadete, pelo menos no campeonato que a gente trabalha, com muito recurso no arremesso...e ai o arremesso vai seguir bem a linha do braço. Por isso, a gente pede pra eles observarem a linha do braço, estar sempre posicionado de frente pro braço do adversário, fazer um scoutzinho porque geralmente não se tem variação do local de arremesso...então é mais isso que se trabalha com eles né. E observar em relação aos pontas, se eles estão buscando o longo ou o curto, isso que a gente cobra dos goleiros. E durante o ataque da sua equipe? Complicado hein? Nós não trabalhamos isso com eles. Como eu te disse, a minha equipe é novata. O ideal é que eles conseguissem observar e dar umas dicas de espaços vazios na defesa adversária, pra que eles conseguissem trabalhar em cima disso. Mas como eles são novatos ainda, eles não tem essa percepção ainda de análise do adversário no ataque e nem na defesa. Quando a gente ta na defesa, o goleiro também não se comunica com a equipe, o que seria importante, porque ele tem a visão do todo, da quadra. 
9. O que um goleiro de handebol deve observar em um arremesso de longa distância (9m) para elaborar a sua tomada de decisão? E em um arremesso de curta distância $(6 \mathrm{~m})$ ? E em uma cobrança de $7 \mathbf{m}$ ?

S1 - De 9metros, de fora, é aquilo que já falei, a leitura. É lógico que no começo do jogo ele não vai ter essa leitura. Você diz leitura do que? Arremesso, trajetórias? Sim, de como o cara adversário vai arremessar, como é a empunhadura dele, como é o movimento de braço dele...de repente ele sobe pra fazer um arremesso de 9metros e faz um arremesso apoiado. Eu tenho que ter essa leitura...ele vai em cima, e depois faz um arremesso em meia-altura, retifica. Então você tem que ter todo esse movimento, esse conceito de defesa. 6metros, explosão, diminuir o espaço do arremessador. Você quer dizer, deslocar avançando e retornando? É, saída em X, aquela explosão em saída em X, alto e embaixo, pra ter essa explosão. Tem que diminuir o espaço do arremessador. De que forma? Isso ai é no momento, tem que ver em que posição ele ta.Entra ai a questão da leitura do posicionamento? Sim, sem duvida, a leitura. E no 7metros, é aquilo: se eu tenho um goleiro alto eu mando subi pros 4 metros; um goleiro mediano eu mando subi pros 2 metros; o goleiro baixinho vai ter que ficar em cima da linha no 7 metros. Isso depende muito do que a gente tem em mão. Se você tem um goleiro alto pra categoria, você pra ele ficar nos 4 metros e ter novamente a noção de leitura no 7 metros pra antecipa o arremesso, porque pegar, não vai pegar.

S2 - As vezes vem uma bola la de fora, dos $9 \mathrm{~m}$, e ela quer fazer o gesto técnico, ai a bola pinga na perna dela e entra. Enquanto que era só ela da um passo pro lado e pronto. Existem arremessos de fora, que a goleira tem que preocupar com a velocidade e a trajetória da bola, se a bola ta no longo ou na curto. E eu gosto que as goleiras fiquem mais em baixo. Mais próximas do gol? Sim, pra que elas tenham tempo de reação pra chegar nessa bola. As bolas de $6 \mathrm{~m}$, de cara a cara, ai a gente treina saída em X, saída em Y...aquela com uma perna no chão, a gente bola com elas 2 ou 3 saídas diferentes pra cada tipo de bola cara a cara, que são as bolas de $6 \mathrm{~m}$, pivôs e contra-ataques.As bolas de ponta, por conta do medo ne, o goleiro nessa idade de 14 e 16 anos, existe muito medo nessas bolas de ponta, por isso que eu coloco a coragem como fator importante, por as meninas tem mais medo nessa idade dos 16 anos. Os meninos por causa da genitália e as meninas principalmente, seios e rosto. Então elas tem muito medo da bola. Às vezes se tem goleiras que com 12 e 13 anos eram loucas e tal, ela vai ficando mocinha, ai começa a ter um problema, principalmente com bola de ponta. Ai a menina vem na cara dela, e ai ela da aquela encolhida assim, e levanta a perna. Então você tem que tirar esse vício delas, antes que ele fique muito forte. Elas tem muito mania de levantar a perna na ponta. Eu gosto que as goleiras na ponta, de 16 anos, como é mais velha e tal..você trabalha se ela cai, se ela não cai, ai você já começa a trabalhar o salto da ponta. Mas aos 16 anos, se você deixar a sua goleira na trave, dando um passo pra dentro na hora do arremesso e fazendo a leitura do braço de arremesso, o arremesso tem que ser muito bom pra entrar no gol. E se essa menina fizer um arremesso muito bom, a goleira não vai conseguir pegar. Se coloca a porcentagem dos arremessos bons que você tem no jogo né, ai você vê aonde que você pode colocar a sua goleira. Às vezes você colocar a sua goleira na ponta, fazendo muitos gestos técnico e tal, você abre mais espaço. Se você deixa a sua goleira esperando mais, você força a atacante a fazer um arremesso mais difícil, mais arriscado, e ai a chance de erro é maior também. E no 7m? Ai é variação né. Nos 7m, eu treino 3 saídas com cada goleira, uma em baixo e duas fora do gol, onde, numa você fica movimentando e na outra você fica parado de com o braço aberto, por exemplo. E em baixo do gol, você vai ficar correndo de uma trave na outra...são formas de você desestabilizar o batedor. O batedor não pode chegar toda hora, e o goleiro estar da mesma forma.

S3 - Longa distância... bloqueio... bloqueio defensivo! Jogar com bloqueio... isso é ....posicionar em um espaço... saber ... ter essa noção! $6 \mathrm{~m}$..... definir o braço do jogador...eu acho que colocar ... se o cara saltou de $6 \mathrm{~m}$ já é uma dificuldade... mas... se você define o braço do jogador.... o corpo no braço.... ele tem uma facilita maior de defender.... e $7 \mathrm{~m}$... scouting... um passo a frente... saber quem é o jogador que está batendo.... onde ele sempre bate... e tentar jogar com ele.

S4 - Eu acho que em relação ao chute de $9 \mathrm{~m}$, a gente ainda tem uma cultura muito ruim em relação as linhas de tiro, que é trabalhar com o bloco defensivo. Então assim: a minha orientação para os goleiros ela prioriza o posicionamento e as diagonais que esse atacante vai tomar a decisão, seja ele na meia esquerda ou na direita, principalmente se na meia direita, ele é um canhoto. Então algumas trajetórias longas ou algumas trajetórias curtas, aonde ele vai saber trabalhar com as situação de longo e curto...o que ele vai precisar, principalmente por questões de braço, um braço mais aberto ou um braço mais fechado, pra ele priorizar essas ações de 
posicionamento. Em relação a bola de $6 \mathrm{~m}$, ai a orientação é trabalhar com avanço em profundidade em relação ao braço do arremesso. Esses avanços tem que ser feitos de maneira posicionada, sempre priorizando fechar os espaços do braço de arremesso. Então às vezes, elas até confudem essa situação com sair demais e tomar uma vasilina, por exemplo. Então é o reforço né: "não, você tem que estar em profundidade em relação com o atacante mas na linha do braço. E no $7 \mathrm{~m}$, eu tenho trabalhado mais leituras com elas "ah, a menina que é a mais batedora, então vamos analisar a batedora"...se a predominância dela é mais do lado esquerdo ou do lado direito, se faz com ou sem queda...um estudo mais aprofundado, baseado muito mais em estatística. Mas vamos pensar assim: se em uma primeira cobrança, você não conhece o batedor...o que você orienta? Bem, na verdade o que eu tenho feito são duas situações: 1- a menina não fez chute nenhum, ai a goleira tem a liberdade de definir aonde ela se sente mais confortável, seja mais a frente, seja mais atrás...ai a tomada de decisão eu deixo a cargo delas. A partir dai a gente passa a ter uma estratégia. Mas se essa menina já fez algum chute no jogo "ah, ela é a central, e só chutou do lado esquerdo", ai a gente já entra com uma estratégia de chute do tipo "oh, ela tem uma leitura de chute, analisa o braço, porque ela pode priorizar o lado que ela já vem chutadando". Então são duas tomadas de decisão que a gente trabalha.

S5 - A única coisa que eu cobro dos goleiros é pra que ele não mecanize os movimentos. Por exemplo: chute de pivô com giro e salto, é pra ele variar as estratégias. Se ele sai, talvez provoque um erro de tentativa de vaselina, se chuta rápido e ele ocupa espaço, essa bola acaba batendo nele, diminuindo o ângulo do atacante..a gente da algumas informações nesse sentido. No $7 \mathrm{~m}$ da preferência pro chute cruzado, mas observar a angulação do braço, saber se o atacante chuta rápido ou se ele ameaça em mais tempos, de não cair antes, de não se jogar ou escolher cantos. Tem goleiro que gosta muito e escolher canto e isso é ruim. Embora eu dê a informação que quase sempre o chute é cruzado, não vai antes. Espera. Não pode mecanizar, mas é pra prestar atenção no caso? Isso, pra ajudar a antecipar o movimento

S6 - Então, o que a gente tenta colocar pro jogador né...primeiro que assim, hoje existem estudos que falam em relação aos armadores, se o meia faz uma trajetória mais arredondada e vem chutar mais do meio da quadra, a tendência é que ele faça mais um chute cruzado, quer dizer um chute no curto. Então, a gente trabalha primeiro com os goleiros, as tendências né, se ele vai chutar uma bola mais reta, mais na posição dele, ou mais aberta, sem tanto ângulo, a tendência é de uma bola no longo...ai através desses estudos, normalmente, eles acabam chutando essa bola no curto. Então a gente tenta passar pra eles, toda essa questão das tendências, a partir dai, cada jogador tem uma tendência de chutar uma bola mais gaveta, ou mais diagonal baixa, ou mais no curto, então a gente pede mais, no caso das bolas de $9 \mathrm{~m}$ que eu to falando primeiro, é que ele consiga fazer um scout individual dos jogadores e depois de um tempo possa estar tomando essas decisões, principalmente quando as bolas são fortes, ai tem que acabar antecipando um pouquinho pra da tempo de chegar na bola né? Então eu acho que um bom posicionamento e a gente estudando as tendências, tanto das trajetórias, no caso de um jogador em si né, a gente pode traçar uma estratégia pra estar mais pronto. Lógico que ele pode estar surpreendendo, uma munheca, um arremesso diferente ali de um lado ou do outro, ai o goleiro já tem que trabalhar com o apoio do peso do corpo em uma perna ou na outra pra ta explodindo, então é importante isso ai pro arremesso de $9 \mathrm{~m}$. Já pra bola de $6 \mathrm{~m}$, de $7 \mathrm{~m}$ e de ponta, a gente trabalha também..pro $7 \mathrm{~m}$ por exemplo, essa questão visual, a gente pede pro goleiro observar o jogador que vai bater, pra ver se ele ta dando alguma dica do lado que vai jogar...principalmente na base, eles não tem ainda essa capacidade de olhar pra um lado e chutar do outro, ou mesmo na hora da cobrança, da uma olhadinha pro canto que vai pra chutar. E também tem a questão do scouting. A gente teve esse ano nos jogos da juventude, a gente acabou indo pra final, ganhando um jogo nos $7 \mathrm{~m}$, graças a um trabalho que a gente fez né , junto com os assistente técnico, onde a gente identificou quem era cobradora oficial dos $7 \mathrm{~m}$ e a outra menina também que cobrou algumas bolas. A partir dai a gente orientou a goleira, e ela conseguiu pegar dois $7 \mathrm{~m}$ que foram decisivos. Então mesmo nos $9 \mathrm{~m}$ ou nos $6 \mathrm{~m}$, mesmo essa questão da bola ou da munheca, de repente ta tendenciando pra um lado ou pro outro, é importante o goleiro saber, tanto pra pivôs ou pros pontas, as bolas de segurança que eles tem ne, que seriam as bolas que eles vão ta buscando a finalização e ai no caso com relação a postura, é nas bolas mais próximas, a gente acaba orientando o goleiro a crescer, a ser um "pavãozão" mesmo, se apresentar mais, pra tentar limitar, inibi um pouco a ação do atacante.

S7 - No arremesso de 9m, o braço de arremesso. Até porque, como a distância é maior, ele tem um maior tempo de reação, vamos dizer assim. Então ele conseguir olhar pro jogador e ver a trajetória do braço. Num arremesso mais cara-a-cara, eu peço pra acompanhar um pouco mais com o corpo e fechar de acordo com a queda do 
jogador. Então, se o jogador está indo mais para a lateral da quadra, eu peço pra ele fechar o curto porque essa bola vem mais fácil e reagir pro longo, porque geralmente é esse o arremesso que ele vai pedir mais. E no $7 \mathrm{~m}$, eu peço pra ele antecipar e escolher lado. Se a gente já tem um scouting prévio do jogador, eu peço pra ele antecipar de acordo com o scouting. E se não tem, a gente mais ou menos assim: "ah, esse jogador, durante o jogo bateu muita bola alta no longo" ou "ah, ele é destro, provavelmente ele vai bater muita bola do lado direito dele, e do seu lado esquerdo.

S8 - É o que te respondi na pergunta anterior né, scoutear o atacante, ver qual a tendência do arremesso dele, ai ele consegue fazer uma defesa mais precisa. Na categoria menor, a gente não trabalhar com a defesa trabalhando com o goleiro..." ah fecha o curto, que o goleiro vai pegar o longo", até porque pra eles é mais difícil de estar assimilando isso. Mas pro goleiro, a gente pede que no arremesso de $9 \mathrm{~m}$, não se antecipar muito não tentar advinhar mesmo, e por ser de longa distância tentar ir na bola mesmo, se posicionar bem e tentar ir na bola. No arremesso de $6 \mathrm{~m}$, ele se antecipar e ai tentar fechar um espaço pra tentar buscar. Por exemplo: se ele da o curto, ele vai buscar la, que é pra ele provocar o erro do adversário, o erro do atacante né. E no 7m é scoutear mesmo, não tem jeito, "ah, a primeira bola desse atleta, é a bola de segurança dele, que é sempre do lado direito em baixo"....então vai busca essa bola, se antecipa e tenta pegar. Você indica alguma característica para ele poder fazer esse "scouteamento" do adversário? A gente indicar sim, pra ele fazer essa observação do braço do atacante..se o cara...no caso a gente trabalha mais com o feminino né, então.."se a menina esta caindo com o braço baixo, dificilmente esse arremesso vai ser em cima". Então essa menina já tem que estar buscando fazer uma queda, buscando ocupar o espaço inferior. Se ela está mais em cima, qual que é a tendência do arremesso, tentar sair em "X", estar buscando o longo. Então é trabalhar realmente nessa visão de buscar o braço, se está equilibrado, se está desequilibrado, em relação a postura, pra poder executar a defesa.

S9 - Num arremesso de 9m, ele deve observar onde está o bloqueio, que a gente geralmente utiliza um bloqueio por curto, e a ideia é o goleiro fechar o longo...porque se a bola sai a direita ou a esquerda do bloqueio, ele tem essa noção de fechar o espaço pra uma bola reta, dificultando essa retificação do arremesso do atacante. Num arremesso dos $6 \mathrm{~m}$, é sempre encurtar mesmo a distância, dificultar mesmo na frente, saindo um pouco e fechando o ângulo, diminuindo os ângulos na verdade, pra que ele tenha uma dificuldade maior pra finalizar. E a saída em " $X$ " é normalmente uma saída que a gente utiliza, que todo mundo utiliza pra um arremesso cara-acara. Nos $7 \mathrm{~m}$ a gente também trabalha com uma diminuição do ângulo, então fica sempre um pouco a frente, mas tendo sempre uma preocupação em relação a recuperação pra uma bola de vaselina.

S10 - Dificil essa pergunta hein? Mas vamos lá...na verdade, no arremesso de 9m, o trabalho colaborativo né...a gente combina que dependendo da situação, o goleiro vai definir um lado da quadra, ou um lado do gol, ele vai definir o curto ou o longo. Depende muito se é um chute do centro da quadra, ele não muito o que definir, ele vai estar no meio do gol pra fazer a intervenção. Mas se vem das laterais, geralmente, ele vai defender o curto e a defesa fica responsável pelo longo e isso vai variar muito em relação aonde o atacante chutou e em relação ao scouting feito em cima desse atacante. Mas no cadete, a gente já costuma fazer essa defesa colaborativa, principalmente para os chutes de $9 \mathrm{~m}$ e $12 \mathrm{~m}$, que tem acontecido bastante, já que a molecada tá muito forte e as meninas também não tem deixado a desejar nessa questão de chutar de $9 \mathrm{~m}, 10 \mathrm{~m}, 11 \mathrm{~m}$. Então vai depender, do scouting feito sobre esse atacante. "Olha, ele chuta muita bola no longo"..então a gente já combina que o goleiro vai fechar o longo e a defesa vai fechar o curto porque se a bola bate na defesa, ela vai pra fora. Se ela bater na defesa e a defesa estiver fechando o longo, a chance é muito grande dessa bola bater na defesa e ir pro gol, então a gente faz essas trocas. No chute de $6 \mathrm{~m}$, a gente brinca com a explosão né, de tentar induzir o adversário ao erro. Então, que que o goleiro vai fazer: uma hora ele vai explodir em cima do adversário pra tentar induzir um vaselina mal-sucedida. E ai entra denovo o trabalho colaborativo com a defesa que vai dar aquele contatinho pra desequilibrar o jogador, não deixar ele arremessar equilibrado. Se deixar ele arremessar equilibrado, a gente vai recorrer novamente ao scouting "Oh, esse cara ta entrando e ele chuta muito quicado, então já fica embaixo, não preciso explodir, faz o esquadro em baixo", vai depender muito do scouting. No jogo, a gente brinca com isso, de ter alguém anotando, fazendo o scouting. Quando esquece o caderninho, a folha de scouting, eles já fazem isso mentalmente, eles já ficam observando "oh, a maior parte dos chutes foi ali". E ai dentro do que é combinado, o goleiro vai tentar tomar a decisão correta ali né. O tiro de $7 \mathrm{~m}$, além do scouting, vai muito do feeling do goleiro né. Então, se eu estou com o meu goleiro mais alto, a gente vai sempre trabalhar com ele adiantado. Se é um goleiro mais baixo, ele vai brincar de ir e voltar, porque não vai adiantar também ele ficar la socado dentro do gol que a chance dele tomar o gol vai ser a mesma. Então, no 7m, a ideia com os nossos 
goleiros é induzir o adversário a errar, jogar uma pressão psicológica e induzir o adversário a errar. E ai, é lógico, observar o braço, o gesto técnico. Se ele observa, se ele fica o tempo inteiro de olho no gesto técnico, ele consegue no $7 \mathrm{~m}$, por exemplo, ele consegue chegar na bola. Se ele consegue observar que o cara abre muito o braço, ele consegue chegar na bola, ele consegue prever pra onde que vai esse arremesso, pra onde é que vai esse chute. Mas, no feminino, geralmente quem bate $7 \mathrm{~m}$, bate na porrada, bate muito forte. A gente tem observado nos jogos da Liga Paulistana, por exemplo, que os $7 \mathrm{~m}$ convertidos no jogo feminino, são mais fortes. Já no masculino, a gente já tem mais a variação de arremesso né, já vê alguns atletas mais técnicos batendo $7 \mathrm{~m}$, e ai pro goleiro fica um pouco mais difícil né. Por isso, fazer com o que o goleiro se movimente um pouco mais, que ele avance e volte pra recuperar a posse da bola, tem surtido efeito...a gente tem pego alguns $7 \mathrm{~m}$, em momentos importantes do jogo. Voltando a falar um pouco sobre os chutes de $9 \mathrm{~m}$ e $6 \mathrm{~m}$, pra gente é sempre muito importante, que o nosso goleiro saiba fazer a leitura da trajetória. Porque acreditamos que a leitura da trajetória, define $70 \%$ da direção do chute. Se o jogador vai pra uma trajetória pra fora, a gente já sabe que o chute é do curto pro meio do gol. O cara vai ter que ser muito bom pra meter essa bola no longo, então o goleiro já fica ali fechando o curto. Se é um jogador que já fica ali, batendo na diagonal pra dentro, ai já vem o trabalho colaborativo com a defesa. Nos $6 \mathrm{~m}$, é obvio que o jogador já passou da defesa, ai o trabalho colaborativo com a defesa vai ser o de desequilibrar o chute. Dentro da regrar do jogo, a gente sabe que a gente consegue desequilibrar o chute. E ai, fazendo com que o cara arremesse desequilibrado, o goleiro consegue prever pra onde essa bola vai. A ideia não é que o goleiro tente adivinhar o canto, mas que ele tenha essa leitura da trajetória e que esteja o mais próximo possível dessa trajetória, pra fazer a sua intervenção.

S11 - Então, como eu disse já, o posicionamento de braço, quadril, a rotação de tronco, enfim tudo isso influencia nesses arremessos...velocidade também, posicionamento em quadra. Pra mim são essas coisas que tem que observar. Essas características são independentes da distância do arremesso? Você utiliza algumas situações para os $7 \mathrm{~m}$. Por exemplo: o $7 \mathrm{~m}$ é parado, então você não tem uma movimentação de espaço, de aceleração de movimento, de velocidade. Então pra cada situação ali, você vai se adequando ali e vai observando algumas coisas né.

S12 - Eu acho que no tiro mais longo, eu treino o goleiro, quando eu tenho que dar uma instrução pra ele, quando o atacante está longe, o goleiro tem que se preocupar com o posicionamento dele, pra onde o atacante ta correndo e se ele está no posicionamento certo. Agora no de 6m, o que eu tento passar pra eles, mas no cadete eu já acho isso um pouco difícil de ter esse entendimento, principalmente em hora de jogo, e eu tento arrumar muito isso na hora do treino....sobre o atacante, o que que esse atacante, na linha dos $6 \mathrm{~m}$, por exemplo, se for um pivô: "é um pivô muito forte, o que tem uma bola mais colocada? "; "Ou se é um atacante ali, que ta entrando com uma finta ali...é pro goleiro tentar esperar um pouco mais, ou tentar sair explodindo dessa bola". E durante uma cobrança de $7 \mathrm{~m}$, é assim, eu tento falar pra ele: "oh, na primeira vez, a gente vai sacar o que esse menino já fez". A gente tem o outro goleiro, que sempre fica anotando, passando alguma informaçãozinha...eu sempre peço pra eles ficarem trocando essas informações...ou alguém que esteja comigo de auxiliar, eu sempre peço isso de ficar observando os arremessos e principalmente de quem está arremessando mais durante o jogo. E ai numa cobrança de $7 \mathrm{~m}$, aquela coisa né "oh, aquele atacante, ele sempre coloca uma bola mais quicada, ou um bola mais forte ou fraca”. Isso, pra saber se o meu goleiro adianta mais, ou se ele espera mais de baixo da trave.

S13 - Bem, 9m basicamente ele tem que observar a velocidade do jogador. Normalmente, quando esse jogador pega a bola em progressão, isso da a denotação de que ele vai executar um arremesso de fora. E ai combinando com isso, vendo o sentido de movimentação em velocidade do jogador, a alavanca de braço, como eu já tinha comentado. Nos $6 \mathrm{~m}$, ai ele tem que estar observando também, a forma com que o jogador está saltando. Se está saltando na direção do goleiro, se está saltando em diagonal e o posicionamento de braço, se o braço está posicionando alto ou se está posicionado baixo. Normalmente nas categorias de base, o recurso de finalização, ele ainda é pequeno. Então, quando do posicionamento de braço baixo, é 95\% de chances de esse jogador estar finalizando a bola em posições baixas. Enquanto que no braço alto, essa porcentagem se transforma em meioa-meio. Basicamente observando isso, e ai da observação também do direcionamento do salto, se ele está saltando mais acima ou se ele está saltando mais em profundidade. Dos $7 \mathrm{~m}$, eu ensino o meu jogador a avaliar os chutes que o cobrador tem feito até agora, ou até aquele momento...se ele chutou a maioria alto ou a maioria baixa, a probabilidade de ele fazer o mesmo no $7 \mathrm{~m}$ é muito grande. 
S14 - No arremesso de 9m, ele tem que trabalhar principalmente com a observação, pra saber o momento certo em que ele vai arremessar, pra que ele possa se colocar em uma posição mais favorável a defesa. Num arremesso de $6 \mathrm{~m}$, que é bem mais próximo, ele tem que ser explosivo e trabalhar na observação do braço do atacante...pra ver se o braço do atacante ta baixo, que dificilmente vai conseguir levantar essa bola, então a movimentação vai ser um pouco mais pra baixo, se o braço ta alto...observar pra ve se ele vai ter que fazer uma movimentação mais explosiva. Num tiro de $7 \mathrm{~m}$, a verdade é que o goleiro não sabe exatamente o que ele tem que fazer. Ele geralmente marca o adversário e define basicamente a movimentação do corpo do adversário. Quando ele já conhece o adversário, ele sabe onde que ele vai bater a maioria das bolas e quando ele não conhece, ele observa a rotação do tronco do adversário...se ele gira o corpo além de $90^{\circ}$, ele bate a bola cruzando, se ele gira o corpo menos de $90^{\circ}$, ele bate a bola do lado esquerdo do goleiro, se o batedor for destro. Então são essas as observações básicas que o goleiro tem que fazer.

S15 - Bom, longa distância eu acho que é um trabalho de explosão mesmo, fazer a leitura do chute, não acompanhar...eles tem a mania de acompanhar a passada, tanto do lado esquerdo, do direito ou do central, ai o atleta acaba quebrando a munheca e tirando ele da situação de defesa. Já nas bolas de $6 \mathrm{~m}$, é uma bola de reflexo puro, e a gente procura condicioná-los nos fundamentos do reflexo pra que ele consiga fazer uma leitura do braço do atleta, o que é fundamental, pra que ele consiga fazer as defesas. Nos $7 \mathrm{~m}$, a gente procura orientar pra fazer variações de posições né, ou bem a frente, ou dentro do gol, pra que consiga chegar nas bolas. Aliás, em todas as distâncias, ele tem que fazer ai variações de defesas, pra também confundir o batedor.

S16 - Bom, num arremesso de 9m, o arremesso é mais força do que colocação. Então eu peço para que os goleiros joguem um pouco mais avançado, pois eles vão estar fechando a linha meia-altura baixo, então eles vão estar oferecendo uma bola que teoricamente é uma vasilina. Como o arremesso de $9 \mathrm{~m}$ é força, você vai estar fechando o espaço de arremesso, então você vai estar fechando o ângulo de arremesso do jogador. Num arremesso de 6m, tipo um arremesso de pivô, se colocar de acordo com o braço de arremesso, para que ele tenha que fazer uma retificação de movimento. Se você fechar o corpo, você vai deixar o braço livre e a linha (de arremesso) do lado curto do atacante, fica mais aberto. Num arremesso de $7 \mathrm{~m}$ você tem dois tipos de colocação: se o arremessador que vai cobrar o $7 \mathrm{~m}$ é força, eu peço para que o goleiro adiante, para que aconteça a mesma situação do tiro de $9 \mathrm{~m}$. Estaria fechando um pouco mais o ângulo, só que deixaria mais aberto, a parte superior. Se é um arremessador que tem mais habilidade no arremesso, tipo, ele pode dar uma vasilina ou uma rosqueta, então eu peço pro goleiro ficar um pouco mais dentro do gol.

S17 - No arremesso de 9m, a trajetória da bola. Alguma característica do jogador? Com certeza, quem chuta mais, aonde chuta mais, qual o chute mais forte. Tudo isso ele tem que estudar. Nos $6 \mathrm{~m}$, ai é questão de posicionamento do corpo durante o salto do atacante e do posicionamento do goleiro. Tem muita gente que salta em direção ao gol e tem gente que faz saltos laterais, que é o mais correto. Numa cobrança de $7 \mathrm{~m}$, é olho no olho, apenas isso.

S18 - Nos arremessos de 9m, a empunhadura do jogador, pra saber onde ele vai atacar, onde ele jogar essa bola, tem que estar muito atento. E o posicionamento dele. Nos $6 \mathrm{~m}$, também a empunhadura, a definição do jogador é muito importante, esperar aonde o jogador ai definir. Nos $7 \mathrm{~m}$, é um pouquinho mais complicado. Mas eu também acho que é significativo a posição do braço do jogador. $\mathrm{O}$ goleiro tem muito isso né, define o lado pela posição do braço.

S19 - Nos 9m, postura de braço e análise do arremesso mesmo do atleta, que é um arremesso mais potente, de longa distância, ele tem uma velocidade de reação maior. Então essa postura dele, de estar bem posicionado e fazer a análise do movimento do jogador ajuda bastante na hora de ele defender o arremesso. Nos $6 \mathrm{~m}$, observar se o jogador arremessa em dois tempos, se ele arremessa no primeiro movimento, porque dai a postura defensiva vai ser diferente e observar a posição do corpo, pra ver se ele está com o tronco elevado, se ele está com o braço abaixado ou se está a $90^{\circ}$. Esses detalhezinhos ajudam o goleiro a identificar aonde provavelmente vai ser o arremesso. Nos $7 \mathrm{~m}$, vai nessa avaliação da postura corporal também e no scouting do próprio atleta também, que geralmente ele tem um lado de preferência pra bater o chute. 